THE UNIVILRITTY OF MANITOBA

\title{
LIBRARY
}

AUTHOR .. BERTHOLET Je frey. Christopher.

TITLE . . EFFECT OF TRIFLURALIN AND METRIBUZIN ON FABABEAN GROWTH

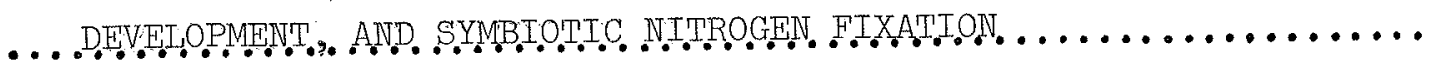

THESIS

I, the undersigned, agree to refrain from producing, or reproducing, the above-named work, or any part thereof, in any material form, without the written consent of the author:
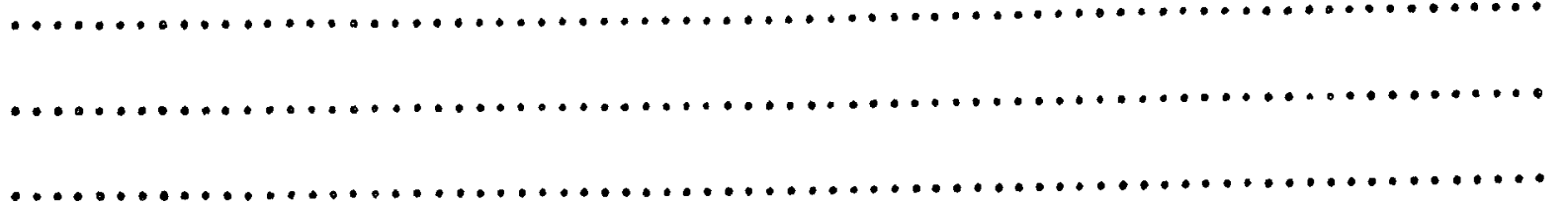

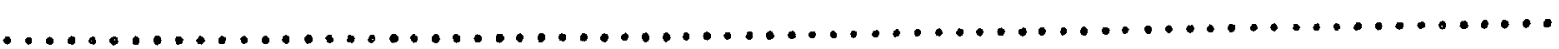

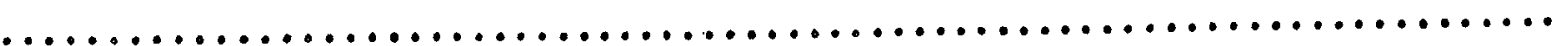

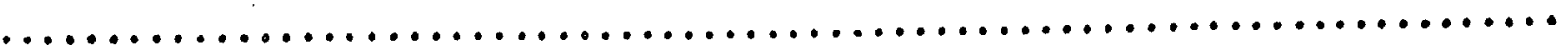

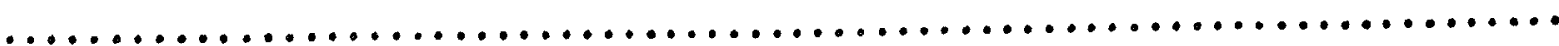

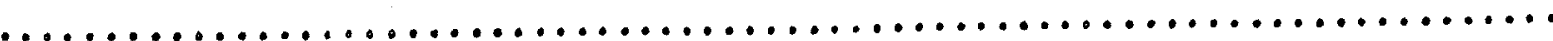

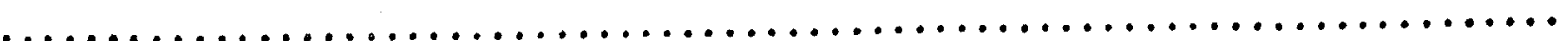

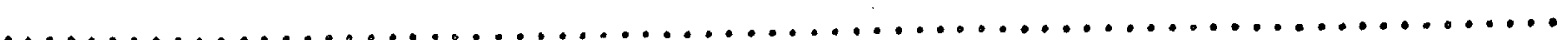

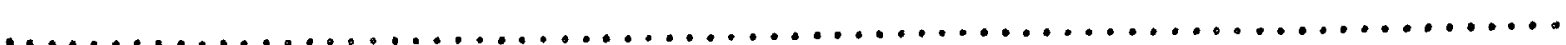

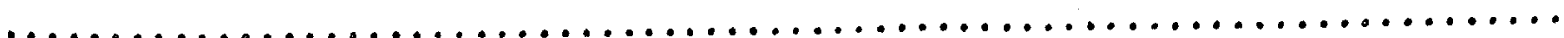

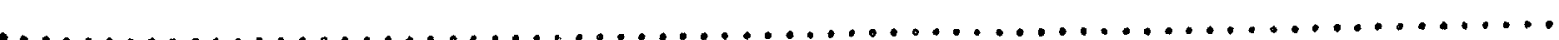

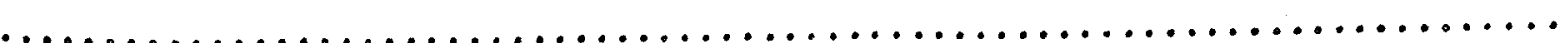

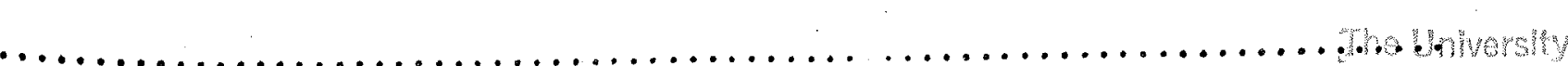

on Mathos

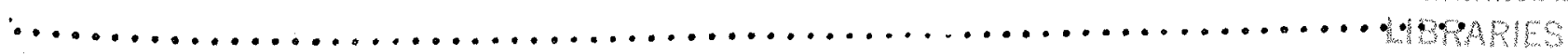




\title{
EFFECT OF TRIELURALIN AND METRIBUZIN ON FABABEAN GROWTH, DEVELOPMENT, AND SYMBIOTIC NITROGEN EIXATION
}

\author{
A Thesis \\ Submitted to the Faculty \\ of \\ Graduate studies \\ The University of Manitoba \\ by \\ Jeffrey Christopher Bertholet \\ In Partial Fulfillment of the \\ Requirements for the Degree \\ of \\ Master of Science \\ Department of Plant Science \\ February 1984
}


THE UNIVERSITY OF MANITOBA

FACULTY OF GRADUATE STUDIES

The undersigned certify that they have read a Master's thesis entitled: . . . EFFECT OF. TRIFLURALIN AND METRIBUZIN

ON FABABEAN GROWTH, DEVELOPMENT,

AND SYMBIOTIC NITROGEN FIXATION

submitted by $\ldots$ Jeffrey Christopher BERTHOLET

in partial fulfillment of the requirements for the degree of MASTER OF SCIENCE

The Thesis Examining Committee certifies that the thesis (and the oral examination, if required) is:

Approved
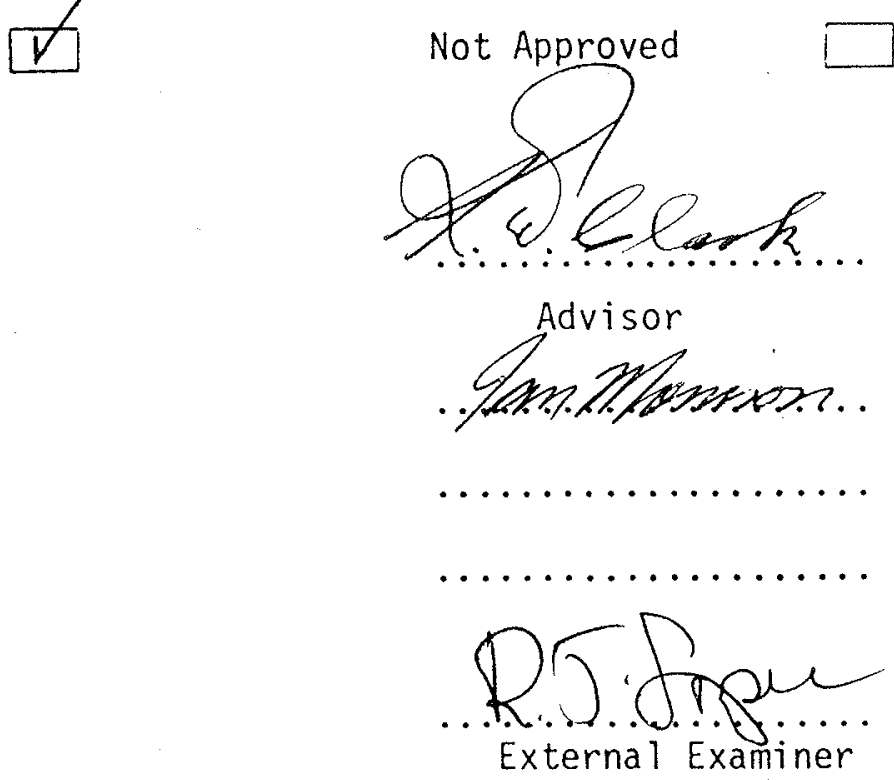

Date . Dẹcember .9. . 19983 


\author{
EFFECT OF TRIFLURALIN AND METRIBUZTN \\ ON FABABEAN GROWTH, DEVELOPMENT, \\ AND SYMBIOTIC NITROGEN FIXATION
}

by

Jeffrey Christopher Bertholet

\begin{abstract}
A thesis submitted to the Faculty of Graduate Studies of
the University of Manitoba in partial fulfillment of the requirements of the degree of

MASTER OF SCIENCE
\end{abstract}

(c) 1984

Permission has been granted to the LIBRARY OF THE UNIVER-

SITY OF MANITOBA to lend or sell copies of this thesis, to the NATIONAL LIBRARY OF CANADA to microfilm this thesis and to lend or sell copies of the film, and UNIVERSITY MICROFILMS to publish an abstract of this thesis.

The author reserves other publication rights, and neither the thesis nor extensive extracts from it may be printed or otherwise reproduced without the author's written permission. 


\section{AC KNOWLEDGMENTS}

I would like to express my sincere gratitude to Dr. K.W. Clark, my advisor, for the advice and knowledge he imparted during both the course of my studies and the preparation of this manuscript.

The members of my advisory committee, Drs. I.N. Morrison and R.J. Soper, deserve a special thanks, not only for reviewing this manuscript, but also for the guidance and recommendations they provided throughout the study.

The assistance of a number of other people was greatly appreciated. Dr. Larry sernyk whose affability and expertise with computer programs was invaluable when analyzing the data. Ian Brown and the other greenhouse staff for their patience, and knack for always being able to find growth room space. Peter Becker for providing all the Kjeldahl analysis of my plant samples.

I would also like to thank my parents for the support and guidance they have always provided.

The companionship provided by friends, both old and new, enabled me to grow as a person. Their encouragement and understanding will always be remembered.

Finally, I would like to thank my wife, Nina, whose undying love and support facilitated the completion of this thesis. 
PAGE

LIST OF TABLES • • • • • • • • • • • • • • • • • • • • v

LIST OF ILLUSTRATIONS • • • • • • • • • • • • • • • • • vi ABSTRACT • • • • • . . . • • • • • • • • • • • • • viii INTRODUCTION • • • • • • • • • • • • • • • • • • • • • 1

LITERATURE REVIEW • • • • • • • • • • • • • • • • • 4

Effect of herbicides on rhizobium species . • • • • • 4

Indirect effects on nodulation or

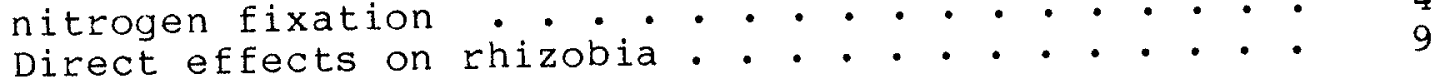

Effect of trifluralin and metribuzin
combinations on plant tolerance . . . . . . . . . . . 13

Reduced phytotoxicity of tankmix . . . . . . . . . 13

Basis of increased tolerance . . . . . . . • 16

Factors influencing metribuzin
activity in the soil..
.

Soil pH • • • • . . . . . . • • • • • • • • • 20

Role of clay, organic matter and
moisture in adsorption . . . . . . . . . . . . 22

Factors influencing trifluralin

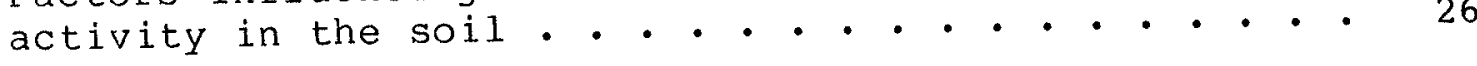

Role of organic matter, clay and . . . . . 26

$\mathrm{pH}$ in adsorption $\cdot$.

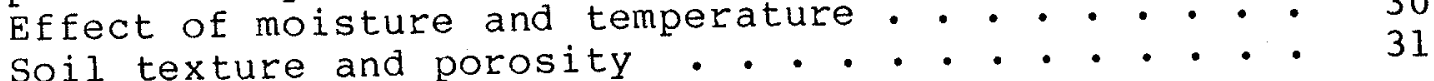

Differential varietal tolerance . . . . . . . . . 32

Evidence from field and greenhouse studies • • • • 32

Hydroponic studies . • • • • • • • • • • • • • 35

Possible mechanism for differential tolerance • • 36 
PAGE

MATERIALS AND METHODS . • . . . . . • . . . . . . • 41

Field trials . . . . . . . . . . . . . . . 4l

Field sites . . . . . . . . . . . . . . . 41

Experimental design . . . • • • • • • • • • • 41

Fertilizer and herbicide application . . . . . . . 43

Sampling methods... . . . . . . . . . . . 46

Nitrogenase activity measurements . . . . . . . . 46

Yield measurements . . . . . . . . . . . . 48

Growth room experiment . . . • • • • • • • • • 48

Hydroponic experiment . . . . . . . . . . . . 51

Experimental analysis . . . . . . . . . . . 53

RESULTS AND DISCUSSION • • • . . • • • • • • • • • • • 54

Field study . . . . . . . . . . . . . . • • 54

Herbicide effects on vegetative growth . . . . . • 54

Nodulation and nitrogen fixation . . . . . . . . . 67

Effects on protein and nitrogen levels . . . . . . 78

Total available nitrogen . . . . . . . . . . 84

Final grain yield . . . . . . . . . . . . . 87

Growth room study . • . . . . • . • • • • • • 92

Selecting for increased tolerance . . . . . . . . 102

Field experiment... . . . . . . . . . . . . 102

Hydroponic experiment . • . . . . . . . • . • • 113

SUMMARY AND CONCLUSIONS • • • • • • • • • • • • • • 107

RECOMMENDATIONS FOR FURTHER STUDIES • • • • • • • • • • 110

LITERATURE CITED • • • • • • • • • • • • • • • • • • • 111

APPENDIX • • • • • • • • • • • • • • • • • • • • 117 


\section{LIST OF TABLES}

TABLE

PAGE

1. Table 1. Available nutrients of field soils at the two sites... . . . . .

2. Table 2. Treatment 1 ist for 1981 field experiment . . . . . . . . . . . . 44

3. Table 3. Treatment list for 1982 field experiment . . . . . . . . . . . . .

4. Table 4. Treatment list for growth room

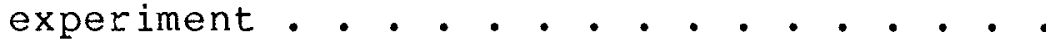

5. Table 5. Precipitation for the 1981 and 1982 growing seasons at field sites . • 64

6. Table 6. Estimate of total available soil nitrogen at the 1982 field site, based on a barley control . . . . . . 86

7. Table 7. Effect of trifluralin and metribuzin on root length, shoot dry weight, and root dry weight

1 week after emergence . . . . . . . 94

8. Table 8. Effect of trifluralin and metribuzin on root length, shoot dry weight, and root dry weight 3 weeks after emergence . . . . . . .

9. Table 9. Effect of trifluralin and metribuzin on root length, shoot dry weight, and root dry weight 5 weeks after emergence . . . . . . 100

10. Table 10. Differential varietal tolerance to metribuzin determined by shoot fresh and dry weights 
LIST OF ILLUSTRATIONS

ILLUSTRATION

PAGE

1. Figure 1. Influence of herbicide application on shoot growth as represented by the fresh weight of above ground plant parts for the years (A) 1981 and (B) 1982. $\mathrm{RH}=$ Inoculated control; $\mathrm{T}+\mathrm{RH}=\mathrm{Trifluralin}$ and Inoculum; $\mathrm{T}+\mathrm{M}+\mathrm{RH}=$ Trifluralin and Metribuzin and Inoculum; $\mathrm{M}+\mathrm{RH}=$ Metribuzin and Inoculum . . . . . . 56

2. Figure 2. Influence of herbicide application on shoot growth as represented by the dry weight of above ground plant parts for the years (A) 1981 and (B) 1982. RH = Inoculated control; $\mathrm{T}+\mathrm{RH}=$ Trifluralin and Inoculum; $\mathrm{T}+\mathrm{M}+\mathrm{RH}=\mathrm{Tr}$ iflural in and Metribuzin and Inoculum; $M+R H=$ Metribuzin and Inoculum . . . . . . 58

3. Figure 3. Influence of herbicide application on plant nodulation based on the dry weight of nodules per plant for the years (A) 1981 and (B) 1982 . $\mathrm{RH}=$ Inoculated control; $\mathrm{T}+\mathrm{RH}=$ Trifluralin and Inoculum; $\mathrm{T}+\mathrm{M}+\mathrm{RH}=$ Trifluralin and Metribuzin and Inoculum; $M+R H=$ Metribuzin and Inoculum

4. Figure 4. Influence of herbicide treatment on nitrogenase activity as measured by acetylene reduction for the years (A) 1981 and (B) 1982. $\mathrm{RH}=$ Inoculated control; $\mathrm{T}+\mathrm{RH}=$ Trifluralin and Inoculum; $T+M+R H=$ Trifluralin and Metribuzin and Inoculum; $M+R H=$ Metribuzin and

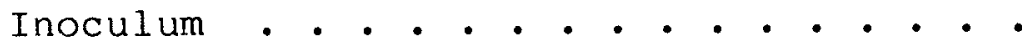


5. Figure 5. Protein content of above ground plant parts as influenced by herbicide application for the years (A) 1981 and (B) 1982. $\mathrm{RH}=$ Inoculated control; $\mathrm{T}+\mathrm{RH}=$ Trifluralin and Inoculum; $\mathrm{T}+\mathrm{M}+\mathrm{RH}=$ Trifluralin and Metribuzin and Inoculum; $M+R H=$ Metribuzin and Inoculum

6. Figure 6. Total nitrogen content of above ground plant parts as influenced by herbicide application for the years (A) 1981 and (B) 1982. $\mathrm{RH}=$ Inoculated control; $\mathrm{T}+\mathrm{RH}=$ Trifluralin and Inoculum; $\mathrm{T}+\mathrm{M}+\mathrm{RH}=$ Trifluralin and Metribuzin and Inoculum; $M+R H=$ Metribuzin and Inoculum

7. Figure 7. Final seed yield as affected by herbicide treatment for the years (A) 1981 and (B) 1982. $\mathrm{CON}=$ Uninoculated control; $\mathrm{RH}=$ Inoculated control; $\mathrm{TR}+\mathrm{RH}=$ Trifluralin and Inoculum; $T R+M+R H$ = Trifluralin and Metribuzin and Inoculum; $\mathrm{M}+\mathrm{RH}=$ Metribuzin and Inoculum. In 1982 all treatments received inoculum . . . . . . . . . . . 
ABSTRACT

Bertholet, Jeffrey Christopher. M.Sc., The University of Manitoba, February, 1983. Effect of Trifluralin and Metribuzin on Fababean Growth, Development, and Symbiotic Nitrogen Fixation. Major Professor; K.W. Clark.

Field studies were conducted to determine if trifluralin [N,N-dipropyl-4-(trifluromethyl)-2,6-dinitroaniline] and metribuzin [3-methylthio-4-amino-6-tert-butyl-1,2,4-triazine$5(4 \mathrm{H})$-onel affect the growth and nitrogen self sufficiency of fababeans (Vicia faba L.). Metribuzin applied at $0.42 \mathrm{~kg} / \mathrm{ha}$ as a pre-plant incorporated treatment resulted in substantial crop injury in 1981. Compared to the inoculated control, average reductions for the growing season, in plant fresh weight, dry weight, nodule dry weight, nitrogenase activity, and yield were $58.3,59.8,85.2,92.9$, and $65.4 \%$ respectively. In 1982 metribuzin at $0.4 \mathrm{~kg} / \mathrm{ha}$ was not as phytotoxic. Averaged over the season, the reductions recorded in plant fresh weight, dry weight, nodule dry weight, nitrogenase activity, and yield were $21.4,25.3,33.0,49.2$ and 9 응 respectively. The differences in phytotoxicity were attributed to differences in soil organic matter, soil $\mathrm{pH}$, and both the degree and timing of rainfall at the two sites. During both years trifluralin did not cause any significant reductions in the parameters investigated. 
When the same rate of metribuzin was applied as a tank mix with $1.1 \mathrm{~kg} /$ ha of trifluralin, a reduction in the degree of phytotoxicity was observed. In 1981 there was a 238 yield improvement from the tank mix compared to metribuzin applied alone. In 1982 decreases in phytotoxicity with the tank mix were evident for the parameters studied, but were not significant at the $0.4 \mathrm{~kg} / \mathrm{ha}$ rate of metribuzin, when averaged over the growing season.

In order to establish a basis for the reduced phytotoxicity of the tank mix, a growth room study was initiated to examine the influence of trifluralin on lateral root development. Trifluralin applied alone or in combination with metribuzin resulted in significant reductions in total root length within the treated layer of soil. The tank mix of trifluralin and metribuzin, at 1.1 and $0.4 \mathrm{~kg} / \mathrm{ha}$ respectively, caused the total root length in the treated layer to be $56.6 \%$ less than the inoculated control one week after emergence. Conversely, the total root length of the plants receiving only the $0.4 \mathrm{~kg} / \mathrm{ha}$ rate of metribuzin did not differ significantly from the control.

Reductions in nodulation and nitrogen fixation were evident only when the crop was injured and the plants under stress from herbicide application. In 1981 metribuzin at 0.4 $\mathrm{kg} / \mathrm{ha}$ caused a 77.8 and $96.5 \%$ reduction in nodule dry weights and nitrogenase activity, respectively, when averaged over the growing season. In 1982 the reductions were less. The 
$0.4 \mathrm{~kg} / \mathrm{ha}$ rate of metribuzin reduced nodule dry weight and nitrogenase activity by only 33 and $49.2 \%$, respectively. Preliminary findings from both field and hydroponic studies suggest that fababean varieties differ in tolerance to metribuzin, as well as do plants within a variety. The possibility exists for selecting both plants within a variety, and varieties themselves, which are more tolerant to metribuzin. 


\section{INTRODUCTION}

Fababeans are an annual grain legume which have proven to be an excellent substitute for soybean meal in livestock feed. An average yield of $2200 \mathrm{~kg} / \mathrm{ha}$ with a protein content ranging from 25-30\% suggests the potential importance of this crop to the livestock industry.

Fababean production in Manitoba, and on a larger scale in Western Canada, has been limited and production has fluctuated. In Manitoba in $1980,8,800$ ha were commercially grown. This decreased to 7,000 ha in 1981 and then to 5,260 ha in 1982. One of the reasons for the limited production, as Betts and Morrison (1978) point out, has been the lack of information available to the producer on products which will provide adequate chemical weed control. This is essential since fababeans are very poor competitors in the early stages of growth.

The registration of the trifluralin and metribuzin tank mix has helped to alleviate this problem. Trifluralin controls a number of annual grassy weeds such as wild oats and green foxtail as well as certain broadleaf weeds such as wild buckwheat, redroot pigweed, and lambsquarters. Metribuzin controls other problem broadleaf weeds such as wild mustard, stinkweed, and smartweed. Together, the tank mix provides a broad spectrum of control of both grassy and broadleaf weeds in a single application which is more economical. The 
application of metribuzin alone is not a recommended practice in Manitoba fababean production.

One of the principle beneficial reasons for growing legume crops is their ability to symbiotically fix nitrogen. Thus it is important to consider any possible effects herbicide application could have, either directly on rhizobium species, or indirectly by affecting the rhizobium/plant symbiosis. Relatively few studies have been conducted in this area. Much of the work that has been done has been performed under the artificial conditions of the greenhouse or laboratory using herbicides other than trifluralin or metribuzin. Thus field investigations of the effects of trifluralin and/ or metribuzin on the nitrogen self-sufficiency of fababeans were considered desirable.

Much of the work conducted in the United States soybean producing areas has indicated that under certain conditions substantial injury can occur as a result of metribuzin application. The use of the trifluralin and metribuzin tank mix has also been investigated and the studies indicate that less injury occurs when the tank mix is applied. The antagonistic effect of trifluralin on metribuzin phytotoxicity has been attributed to reduced metribuzin uptake as a consequence of an inhibition of root development as a result of trifluralin application. Studies to evaluate fababean tolerance to metribuzin applied alone or in a tank mix with trifluralin are limited. None of the studies performed have evaluated the 
effects of the herbicides on root length or nitrogen fixation.

The U.S. studies conducted using soybeans have also demonstrated that soybeans show differential varietal tolerance to metribuzin. This type of study has not been performed with fababeans and would be an important one since the range of fababean tolerance to metribuzin appears to be narrow.

Studies were carried out to: 1) examine any possible effect trifluralin and metribuzin have on nodulation or nitrogen fixation under field conditions; 2) evaluate the 'safening' effect of the trifluralin and metribuzin combination on the basis of root development; and 3) examine the possibility of fababean cultivars differing in terms of their tolerance to metribuzin, and the possibility to select for increased tolerance. 


\section{LITERATURE REVIEW}

\section{Effect of Herbicides on Rhizobium Species}

When one wishes to consider the effect of a possible toxic compound on Rhizobia, the fact that these organisms enter into symbiotic relationships with legumes tends to complicate the situation. Not only must the effect of the herbicide on the bacteria itself be considered, but possible effects on the plant, and the symbiotic interaction must also be examined. Thus two general possibilities exist. Firstly, the herbicide could have a direct effect on the bacteria. This could result in a decrease in nodulation through death or inactivation of the organism. Secondly, the herbicide could have a. detrimental effect on the symbiosis through indirect action. The herbicide may be phytotoxic to the plant resulting in death or injury, with a subsequent decrease in nodulation, or the herbicide may interfere with the nodulation process.

\section{Indirect Effects on Nodulation or Nitrogen Fixation}

A number of researchers have demostrated reductions in nodulation or nitrogen fixation as a result of an indirect action of a herbicide (Carlyle and Thorpe, 1947; Worsham and Giddens, 1957; Peters and Zbiba, 1979; Dunigan, 1972; Brock, 1972; Bethlenfalvay, 1979). 
Carlyle and Thorpe (1947) examined the effects of the ammonium and sodium salts of 2,4-D[2,4-dichlorophenoxyacetic acid] on the nodulation and growth of four legumes. In addition, on synthetic medium, they were able to determine the concentration of the herbicide that would inhibit the growth of Rhizobium leguminosarum, R. phaseoli, R. trifolii, R. lupinii, R. japonicum, and R. melilotii. The different species had quite a wide range of tolerance to the $2,4-D$ salts. Rhizobium trifolii and R. leguminosarum were the most sensitive, with growth being inhibited at concentrations of 0.03 and $0.04 \frac{7}{8}$ respectively. The other species were inhibited at concentrations of approximately $0.3 \%$ A concentration of $0.03 \%$ corresponds to a rate of approximately 224 $\mathrm{kg} / \mathrm{ha}$, so there would not appear to be any possibility of the organisms being directly affected by the herbicide at field rates. When the 2,4-D salts were applied to beans, peas, red clover, and alfalfa at a rate of $0.5 \mathrm{ppm}$ in the soil solution $(0.23 \mathrm{~kg} / \mathrm{ha})$ plant injury was extreme with both growth and nodulation being adversely affected.

Worsham and Giddens (1957) established that dalapon (2, 2-dichloropropionic acid) at 19,38 , and $76 \mathrm{~kg} / \mathrm{ha}$ had no effect on the nodulation of soybeans (Glycine max L.). Plants treated with dalapon were injured, leading to complete necrosis in some cases. The plants that survived recovered in about three weeks time. These recovered plants had higher levels of nodulation than the controls. The authors 
postulated that this resulted from competition, because the control treatments had more plants per pot than did the treated plants.

Peters and Zbiba (1979) evaluated a number of herbicides for their effect on growth, nodulation, and $\mathrm{NH}_{3}$ production of alfalfa (Medicago sativa) and medium red clover (Trifolium pratense). The soil used was made up of equal portions of a Mexico silt loam and sand. The Mexico silt loam contained $2 \%$ organic matter, $27 \%$ clay, $7 \%$ fine sand, and the remainder silt. The treated soil occupied the top $3 \mathrm{~cm}$ of the pots used. With alfalfa, benefin [N-butyl-N-ethyl-4-(trifluoromethyl)-2,6-dinitroaniline] and profluralin [N-(propyl)-N(cyclopropylmethyl)-4-(trifluoromethyl)-2,6-dinitroanil ine]

reduced shoot height and weight, when applied at 1.12 and $1.68 \mathrm{~kg} / \mathrm{ha}$. Only the $1.68 \mathrm{~kg} / \mathrm{ha}$ application of profluralin reduced nodule numbers, and acetylene reduction was not affected. The other herbicides used, diclofop-methyl [Methy] $2-(4-(2,4-d i c h l o r o p h e n o x y)$ phenoxy $)$ propanoate), 2,4-DB(4$(2,4$-dichlorophenoxy) butyric acid], and EPTC (s-ethyl dipropylthiocarbamate) had no significant effect on plant height, weight, or N-fixing capacity.

Red clover plants displayed greater sensitivity. Reductions in plant height and weight occurred with benefin and profluralin at $1.12 \mathrm{~kg} / \mathrm{ha}$, diclofop-methyl at $1.68 \mathrm{~kg} / \mathrm{ha}$, and the combination of $1.12 \mathrm{~kg} / \mathrm{ha}$ of diclofop-methyl with 0.56 $\mathrm{kg} / \mathrm{ha}$ of $2,4-\mathrm{DB}$. None of the treatments significantly reduced nodule numbers or N-fixing capacity, although benefin and profluralin did cause substantial reductions. 
In a second experiment by the same authors, the organic matter content of the soil was lower. For alfalfa a higher degree of injury resulted, with reductions in root weights, nodule numbers, and acetylene reduction occurring with a 1.12 $\mathrm{kg} / \mathrm{ha}$ rate of benefin and with all rates of profluralin. With red clover benefin at $0.84 \mathrm{~kg} / \mathrm{ha}$ significantly reduced nodule numbers as did $0.84 \mathrm{~kg} / \mathrm{ha}$ of profluralin. These reductions were accompanied by shoot and root weight reductions as a result of herbicide injury.

Dunigan et al. (1972) investigated, in both field and greenhouse experiments, the effect of seven herbicides on the nodulation of soybeans [Glycine max (L)] growing on five different soil types. In the greenhouse study, none of the herbicides, including prometryn [2-methythio-4,6-bis (isopropylamino)-s-triazine $]$ and trifluralin [N,N-dipropy $1-4-$ (trifluoromethyl)-2,6-dinitroanilinel, applied at the recommended rates, had any effect on the dry weight of nodules for the plants growing in the higher organic matter level soils $(1.1-1.6 \%)$. On two of the soils which had lower organic matter levels, deleterious effects on nodule dry weights were noted with prometryn, linuron [3-(3,4-dichlorophenyl)-1methoxy,1-methylurea), nitralin (N, N-dipropyl-4-(methylsulfonyl)-2,6-dinitroaniline], and vernolate (s-propyl dipropylthiocarbamate]. This was associated with plant injury as were the reductions observed at higher than recommended rates. 
Brock (1972) studied the effects of trifluralin on the nodulation of the following four legume species, white clover (Trifolium repens

L), red clover (T. pratense L), suckling clover (T. dubrium L) and Lotus pedunculatus. Trifluralin at $1.0 \mathrm{~kg} / \mathrm{ha}$ resulted in significant reductions in nodules per plant and total dry weight per plant. The author found that nodules per plant and root dry weight were positively correlated, and that the numbers of nodules per unit root dry weight was not reduced at $1.0 \mathrm{~kg} / \mathrm{ha}$. Since nodules per unit root dry weight remained relatively constant at rates of trifluralin ranging from .25 to $1 \mathrm{~kg} / \mathrm{ha}$ it was suggested that the herbicide did not have any direct effect on rhizobial infection or nodulation. The reductions in nodule numbers were suggested to result from trifluralin induced inhibition of root growth.

Bethlenfalvay et al. (1979) investigated the effect of bentazon [3-isopropyl-1 $\mathrm{H}-2,1,3$-benzothiadiazin-4-(3H)-one2,2-dioxidel on the symbiotic nitrogen-fixing capacity of bean plants (Phaseolus vulgaris) inoculated with Rhizobium phaseoli. The plants were treated with $1.80 \mathrm{~kg} / \mathrm{ha}$ of bentazon and the parameters measured were $\mathrm{C}_{2} \mathrm{H}_{2}$ dependent $\mathrm{C}_{2} \mathrm{H}_{4}$ production ( $\mathrm{N}$-fixing capacity) and apparent photosynthesis measured by $\mathrm{CO}_{2}$ exchange rate (CER). A minimum CER was reached 6 hours after treatment and $\mathrm{N}$-fixing capability only recovered after the CER became positive. Root treatments produced the same results, although the effects were not as severe. With root treatment there was a six hour 
1 ag period before the $C E R$ and $\mathrm{N}$-fixing capability was reduced. The delay, as the authors postulate, reflects the time necessary for absorption and translocation from the roots to the chloroplasts. The authors suggested that the identical delay times between a positive CER and $\mathrm{N}$-fixing capacity indicates an indirect effect on symbiotic nitrogen fixation through a reduction in the supply of photosynthate.

\section{Direct Effects on Rhizobia}

Garcia and Jordan (1969) examined the effect of 2,4-DB and dalapon on the nodulation of birdsfoot trefoil (Lotus corniculatus). In field studies $2,4-D B$ applied alone or in combination with dalapon at rates of $1.26 \mathrm{~kg} / \mathrm{ha}$ and 4.4 $\mathrm{kg} / \mathrm{ha}$, respectively, reduced nodule numbers and nodule dry weight per plant at both the 3 and 6 week sampling times. Dalapon applied alone reduced nodule dry weights, but the tank mix caused a greater reduction. Plant dry weights were not reduced by either $2,4-D B$ or $2,4-D B$ and dalapon. Dalapon tended to reduce plant dry weights at the later sampling date, but the reduction was not significant. Some of the 2,4-DB treated plants underwent a proliferation of lateral root development and these abnormal lateral roots were found to be less nodulated. In contrast to this, Kunelius (1970) found that 2,4-DB and dalapon applied at 1.43 and $1.67 \mathrm{~kg} / \mathrm{ha}$, respectively, had no effect on nodulation in a field study using birdsfoot trefoil. 
The field results obtained by Garcia and Jordon indicated that reductions in nodulation may be the result of some direct effect of the herbicide on the bacteria. Herbicide application did not result in a decrease in plant dry weight, yet nodulation was reduced. In experiments to determine the possibilities of herbicides having direct action on the organism, the bacteria are usually grown in liquid or solid media containing various concentrations of the herbicide in question. In most instances one of the goals of the researcher is to establish a lethal dose of the herbicide being investigated. As Dunigan et al. (1972) indicate, the lethal dose is usually at concentrations much higher then field rates and consequently, far outside the range of plant tolerance. Thus, plants appear to be more sensitive than the bacteria.

Jordan and Garcia (1969) performed further investigations into the interaction between 2,4-DB and birdsfoot trefoil (Lotus corniculatus) rhizobia to discern the minimum inhibitory concentration (MIC). The effect of $2,4-D B$ at various growth stages of the organism was also studied. None of the concentrations employed completely suppressed growth. Growing organisms were detected in even $500 \mu \mathrm{g} / \mathrm{mL}$ of the herbicide. Optical density values indicated that a partial inhibition of growth occurred at a concentration of 20-50 $\mu \mathrm{g} / \mathrm{mL}$ of $2,4-\mathrm{DB}$. In continuous optical density studies an increased lag in growth was observed for concentrations of $50 \mu \mathrm{g} / \mathrm{ml}$ or higher. This increase in lag was only observed 
when 2,4-DB was added before the log phase of growth. The authors postulated that cells in the lag phase of growth were the most sensitive. There was no inhibition in nodulation as measured by nodule numbers per plant using organisms preincubated with up to $10 \mu \mathrm{g} / \mathrm{mL}$ of $2,4-\mathrm{DB}$.

Gillberg (1971) examined the maximum dose of dinoseb (dinitro-0-sec-butylphenol) or MCPA [2-methyl-4-chlorophenoxy-acetic acid] that a number of strains of Rhizobium meliloti, R. leguminosarum, and R. trifolii could tolerate. The effect of each herbicide was evaluated by plating the organism on $\mathrm{G}: 1$ agar containing a wide range of concentrations of each herbicide. All the strains except one were strongly inhibited by $150 \mu \mathrm{g} / \mathrm{mL}$ of dinoseb. In general the organisms were more tolerant of MCPA, with growth for most strains inhibited by 300-400 $\mu \mathrm{g} / \mathrm{mL}$ of $\mathrm{MCPA}$. Three of the strains investigated were able to tolerate higher levels.

Kasubiak (1966) screened slow and fast growing Rhizobium strains for their tolerance to a number of herbicides. Included in the study were triazines (prometryn and simazine [2-chloro-4,6-bis(ethylamino)-S-triazine]), ureas (1inuron and diuron), carbamate-urea (propham and monuron), and dinitrophenol (dinoseb) preparations. The herbicides were added in varying concentrations to Thorton medium with yeast water. The susceptibility of the organisms was measured by growth in liquid culture. The fast growing strains of $\underline{R}$. meliloti, R. trifolii. amd R. leguminosarum were tolerant of larger doses than the slow growing strains of $\underline{R}$. lupinii and 
R. japonicum. The triazines (simazine and prometryn) along with dalapon were not toxic at up to $20 \mathrm{mg} / \mathrm{mL}$ for the strains investigated. The sodium salt of $2,4-\mathrm{DB}$ inhibited the fast growing strains at $1 \mathrm{mg} / \mathrm{mL}$ and the slow growing strains at 0.1 to $0.5 \mathrm{mg} / \mathrm{mL}$. The ureas (linuron and diuron) and the carbamate-urea (propham and monuron) were found to be the most toxic. Fast growing strains were inhibited by a few hundred $\mu \mathrm{g} / \mathrm{mL}$, and the slow growing Rhizobia at $100 \mu \mathrm{g} / \mathrm{mL}$. Kasubiak (1966) wanted to determine at what stage of growth the organisms were most susceptible to herbicide treatment. The herbicides investigated were linuron, dinoseb, and propham and monuron. The same strains as the previous study were used. Cells that were physiologically more active i.e., log stage, were sensitive to smaller doses of linuron and dinoseb. Propham and monuron did not kill the cells, even at a concentration of $4000 \mu \mathrm{g} / \mathrm{mL}$.

Kust and Struckmeyer (1971) studied the effect of trifluralin rate and depth of incorporation on the growth and nodulation of soybeans (Glycine max L). A 2:1 mixture of sand and Plano silt loam was used. Trifluralin was applied at $0.36,0.74$, and $1.1 \mathrm{~kg} / \mathrm{ha}$. Incorporation into plastic pots was made to two depths, $0-5 \mathrm{~cm}$, and $5-15 \mathrm{~cm}$. At 1.1 $\mathrm{kg} / \mathrm{ha}$ trifluralin significantly reduced top growth regardless of herbicide placement. Rates of 0.36 and $0.74 \mathrm{~kg} / \mathrm{ha}$ reduced top growth only when trifluralin placement was in the $5-15 \mathrm{~cm}$ 
range. Trifluralin at $0.36 \mathrm{~kg} / \mathrm{ha}$ reduced nodule numbers at both incorporation depths without causing a reduction in shoot or root growth. Trifluralin at 0.74 and $1.1 \mathrm{~kg} / \mathrm{ha}$ caused further decreases in nodule numbers with corresponding reductions in shoot and root dry weights. The reduction in top growth (almost $50 \%$ at the $1.1 \mathrm{~kg} / \mathrm{ha}$ rate) after 4 weeks was attributed to both an inhibition of lateral root development and occlusions in the xylem elements. These both would serve to reduce the available water and nutrient supply. For a given rate of trifluralin there were no differences in effects on nodulation for the two placement zones.

\section{Effect of Trifluralin and Metribuzin Combinations} on Plant Tolerance

\section{Reduced Phytotoxicity of Tank Mix}

In order to expand the weed control spectrum and the economy of application, a tank mix of trifluralin [N, Ndipropyl-4-(trifluoromethyl)-2,6-dinitroanilinel and metribuzin [3-methylthio-4-amino-6-tert-buty $1-1,2,4-t r i a z i n e-$ $5(4 \mathrm{H})$-one] is recommended for use in Manitoba fababean production. Metribuzin, applied alone, is not a recommended practice. The margin of tolerance to metribuzin seems to be a narrow one and dependent on a number of environmental and soil parameters. Investigations into possible interactions 
between trifluralin and metribuzin that result in an increase in tolerance have been carried out primarily in the United states soybean producing regions.

Field experiments have been carried out by a number of researchers. Ladlie et al. (1977) found that the tank mix significantly reduced soybean injury compared to metribuzin applied alone. Soybean injury as determined by fresh and dry weights, and crop yield increased as the rate of metribuzin increased from 0.28 to $1.12 \mathrm{~kg} / \mathrm{ha}$. Although reductions in injury occurred as trifluralin rates increased from 0.28 to $0.84 \mathrm{~kg} / \mathrm{ha}$, at least $0.56 \mathrm{~kg} / \mathrm{ha}$ of trifluralin was needed for a significant interaction to occur. Metribuzin at $0.28 \mathrm{~kg} / \mathrm{ha}$ reduced soybean yield to $70 \%$ of the control. However, when trifluralin at $0.56 \mathrm{~kg} / \mathrm{ha}$ was applied in combination with metribuzin, the yield was not significantly different from the control.

Moomaw and Martin (1978) carried out similar experiments on two different soil types. On the Moody silty clay loam (3.7\% organic matter, $\mathrm{pH}$ of 6.5 ) metribuzin at $0.4 \mathrm{~kg} / \mathrm{ha}$ resulted in lower plant dry weights and lower plant stands when compared to trifluralin and metribuzin applied in combination at 0.8 and $0.4 \mathrm{~kg} / \mathrm{ha}$ respectively. The yield of the two treatments did not differ significantly. On the crofton silt loam ( 2.3 organic matter, pH of 7.9) in excess of $60 \%$ of the plants displayed early injury symptoms when treated with $0.4 \mathrm{~kg} / \mathrm{ha}$ of metribuzin. At this rate, the trend was for a 
reduction in stand and plant dry weight as well. The yield of the plants at the $0.4 \mathrm{~kg} / \mathrm{ha}$ rate of metribuzin did not differ significantly from the plants receiving trifluralin and metribuzin at 0.8 and $0.4 \mathrm{~kg} / \mathrm{ha}$, respectively. However, the yield was $165 \mathrm{~kg} / \mathrm{ha}$ lower when metribuzin was applied alone.

Betts and Morrison (1979), in addition to evaluating the tank mix for a possible interaction, examined the effect of both spring and fall applications of trifluralin and metribuzin on weed control and fababean (Vicia faba) tolerance. In field studies fall application of 1.4 and $0.4 \mathrm{~kg} / \mathrm{ha}$ of trifluralin and metribuzin, respectively, resulted in significantly higher yields when compared to 1.1 and $0.3 \mathrm{~kg} / \mathrm{ha}$ of trifluralin and metribuzin applied in the spring. Data on weed densities did not show conclusively that weed control was better with fall application, although the trend was for improved control. Higher yields with the fall application were attributed to greater moisture conservation, and less injury based on crop tolerance ratings.

In 2 out of 3 years of the study, metribuzin at 0.3 $\mathrm{kg} / \mathrm{ha}$ resulted in a significant yield reduction when compared to trifluralin and metribuzin applied at 1.1 and $0.3 \mathrm{~kg} / \mathrm{ha}$. In 1977 a spring application of metribuzin at $0.3 \mathrm{~kg} / \mathrm{ha}$ resulted in a seed yield of $1456 \mathrm{~g} / \mathrm{m}^{2}$ whereas an application of $1.1 \mathrm{~kg} / \mathrm{ha}$ of trifluralin and $0.3 \mathrm{~kg} / \mathrm{ha}$ of metribuzin resulted in a seed yield of $1808 \mathrm{~g} / \mathrm{m}^{2}$. 
Basis of Increased Tolerance

In order to try to establish a basis for the antagonistic effect of trifluralin on metribuzin phytotoxicity, growth room studies examining root growth and ${ }^{14} \mathrm{C}$-uptake were carried out. Betts and Morrison (1979) found that triflura1 in and metribuzin at 1.0 and $0.4 \mathrm{~kg} / \mathrm{ha}$ respectively, significantly increased shoot and root dry weights of fababeans when compared to $0.4 \mathrm{~kg} / \mathrm{ha}$ of metribuzin applied alone. To determine if the reduced injury was due to an inhibition of root growth by trifluralin leading to reduced uptake of metribuzin, effects on root growth were examined. Trifluralin at 1.0 and $2.0 \mathrm{~kg} / \mathrm{ha}$ did not significantly reduce root dry weights of fababeans in this study.

In greenhouse studies Ladlie et al. (1977) and Murray et al. (1979) had similar findings with soybeans. Ladlie et al. (1977) found that trifluralin at $1.67 \mathrm{~kg} / \mathrm{ha}$ did not significantly reduce the dry weight of soybean roots, but the reductions were in the order of 16 to $20 \%$. When ${ }^{14}$ C-uptake studies were carried out it was determined that trifluralin significantly reduced the amount of ${ }^{14} \mathrm{C}$-metribuzin that was taken up. Trifluralin at $1.68 \mathrm{~kg} / \mathrm{ha}$ reduced the level of $14 \mathrm{C}$-metribuzin present in the cotyledons, shoot, and roots of 12 day old soybean seedlings by 48,28 , and $32 \%$ respectively. 
Murray et al. (1979) investigated the effect of trifluralin and two other dinitroanilines on root and shoot growth of cotton and soybean. Trifluralin at 1 ppmw caused a $24 \%$ reduction in root dry weight of soybean plants growing in a Decater clay loam soil.

O'Donovan and Prendeville (1976) demonstrated a more dramatic inhibition of root growth. A charcoal barrier was used to localize the herbicicde in a $5 \mathrm{~cm}$ zone, $2.5 \mathrm{~cm}$ below the surface. Pregerminated seeds of vetch (Vicia satica L..), pea (Pisum sativum), and soybeans (Glycine max.) were placed on this layer. Trifluralin at a rate of $1.0 \mathrm{~kg} / \mathrm{ha}$ did not reduce the shoot growth of any species. However, root fresh weights in the treated zone were reduced by approximately $50 \%$ for the 3 species investigated. There was no visible effect on the tap root, with the reduction in weight being due to a severe inhibition of lateral root growth. The influence of this root inhibition was investigated further by measuring the amount of ${ }^{14} \mathrm{C}-1$ abelled simazine [2-chloro-4,6-bis (ethylamino)-S-triazine] or ${ }^{14} \mathrm{C}-1$ abelled atrazine [2chloro-4-ethylamino-6-isopropylamino-s-triazine] uptake when applied alone or in combination with trifluralin. Triflura1 in reduced total absorption and acropetal translocation of ${ }^{14} \mathrm{C}$-simazine and ${ }^{14} \mathrm{C}$-atrazine in peas and soybeans, respectively. This was correlated with a reduction in shoot injury when compared to simazine or atrazine applied alone. The level of radioactivity retained in the root of peas treated with simazine and trifluralin was higher than the 
amount in the roots of plants treated with simazine alone. Kust and Struckmeyer (1971) reported that trifluralin caused a number of cellular abnormalities in the roots of soybean. These included occlusions in the xylem elements which may reduce the transport of water to the leaves. Since triazines are transported in the apoplast these occlusions could help explain the lower levels of radioactivity in the foliage of the plants treated with the tank mix.

Oliver and Frans (1968) related the degree of lateral root inhibition to the depth of trifluralin incorporation in a field study using soybeans. The depth of incorporation was varied and soybean roots were sectioned into $2.5 \mathrm{~cm}$ segments so that lateral roots could be counted. Trifluralin at 1.1 $\mathrm{kg} / \mathrm{ha}$ incorporated to a depth of $5 \mathrm{~cm}$ caused a severe reduction in the number of lateral roots on the second $2.5 \mathrm{~cm}$ segment. The authors concluded that incorporation to just below the seed or deeper resulted in the greatest injury. The authors also suggested that perhaps a compensatory production of lateral roots below the treated zone was occurring. The data, particularly for cotton (Gossypium hirsutum L.) roots, indicated that this may, in fact, be happening. The number of lateral roots increased in each segment below the treated layer, with the greatest number occurring in the first $2.5 \mathrm{~cm}$ segment below the treated layer.

Bayer et al. (1967) examined the effects of trifluralin on the development of cotton, safflower (Carthomus 
tinctorius), and watergrass (Echinochloa crusgalli) roots. A treatment of $10^{-4} \mathrm{M}$ for cotton and $10^{-6} \mathrm{M}$ for watergrass resulted in increased radial expansion of the primary root near the root tip. At this concentration there was a gradual decrease in the meristematic zone as treatment time increased. Cells in this zone underwent progressive vacuolation and eventually differentiation, decreasing the meristematic area.

To investigate the effect of trifluralin on lateral root development, lower concentrations were used. The herbicide was applied at $1.1,2.2$, and $4.4 \mathrm{~kg} / \mathrm{ha}$ to a 2.5 inch layer of soil within a 14 inch column. In the trifluralin treated zone lateral root formation of cotton was inhibited. When cross sections of the roots in this region were examined, all tissues appeared to be developing normally, except the pericycle and portions of the endodermis. The pericycle cells were enlarged in the region opposite the protoxylem where lateral roots are initiated. The number of cell layers of the pericycle was also reduced. The authors suggested that the development of lateral root primordia had been prevented because of abnormal cell division in the pericycle. The meristematic tissue of the primary root tip appeared normal. 


\section{Factors Influencing Metribuzin Activity in the soil}

Soil pH

Bailey and white (1970) in their review indicate that surface acidity is probably the most critical property of the soil colloidal system in determining the extent and nature of adsorption of basic organic compounds. Weber (1980) determined the pKa of metribuzin and prometryn to be 1.1 and 4.1 respectively. Based on ionization constants, the percentage of molecular and ionized metribuzin can be calculated at varying levels of $\mathrm{pH}$. At $\mathrm{pH}=2$ there is $89 \%$ of metribuzin in the molecular form and $11 \%$ in the ionized form. At $\mathrm{pH}=4$ or above $100 \%$ exists in the molecular form. Since metribuzin acts as a weak base it accepts a $\mathrm{H}^{+}$at low $\mathrm{pH}$ and exists as a cation. Both of these herbicides can be adsorbed by ion exchange forces at low $\mathrm{pH}$, whereas at higher $\mathrm{pH}$ only physical adsorption takes place. Weber et al. (1969) investigated the adsorption of seven s-triazines. The adsorption studies were conducted at $\mathrm{pH}=1,2,4$, and 5.2 . The greatest amount of adsorption was found to occur in the $\mathrm{pH}$ range that was closest to the pka of each herbicide. Prometryn, hydroxypropazine, and prometone with pKa values ranging from 4.05 to 5.20 were adsorbed in the greatest quantities at $\mathrm{pH}$ levels from 4.2 to 5.2. Propazine with a pka of 1.85 was adsorbed in the greatest amount at $\mathrm{pH}=2.0$. Bailey et al. (1968) reported that 
montmorillonite clay surface acidity can be up to $3-4 \mathrm{pH}$ units lower than the pH of the bulk solution.

Ladlie et al. (1976) conducted a series of experiments into the effect of $\mathrm{pH}$ on metribuzin activity, adsorption, mobility, microbial degradation, and dissipation. Field studies were performed using a sandy loam soil containing 1.5\% organic matter, 53\% sand, $22 \%$ silt, and $25 \%$ clay. The $\mathrm{pH}$ values that were investigated were $4.6,5.1,5.6,6.1$, and 6.7. Metribuzin was applied pre-emergence at $0.0,0.56$, 0.84 , and $1.12 \mathrm{~kg} / \mathrm{ha}$. In the greenhouse studies the same soil was used and metribuzin was applied at $0.28,0.56,0.84$, and $1.12 \mathrm{~kg} / \mathrm{ha}$. In addition sand was also used. Results of the field studies indicated injury increased with pH. At the $\mathrm{pH}$ range 6.5-6.9 soybean yield was reduced to $76 \%$ of the control. There appeared to be a dividing line between slight and severe injury. Above $\mathrm{pH}=5.4$ the injury was much more severe. In the greenhouse, the plants growing in the soil showed a pH response as well. A rate of $0.28 \mathrm{~kg} / \mathrm{ha}$ caused a $25 \%$ reduction in the dry weight of soybeans as the $\mathrm{pH}$ was raised from 4.6 to 6.7 . In sand, the injury was much more dramatic, but there was no $\mathrm{pH}$ response. This would indicate that changes in $\mathrm{pH}$ influence adsorption and thus availability of metribuzin.

Ladlie et al. (1976) collected samples of the previously described field soil in order to determine the influence of $\mathrm{pH}$ on microbial degradation of radioactive metribuzin 
$-5-{ }^{14} \mathrm{C}$. Metribuzin was readily degraded over a twelve week period and degradation $\left({ }^{14}{ }^{4} \mathrm{C}\right.$ evolved as $\left.{ }^{14} \mathrm{C} 0_{2}\right)$ increased as $\mathrm{pH}$ increased. There was a significant correlation between degradation and soil $\mathrm{pH}(r=.993)$. A treatment of the soil with sodium azide which results in sterile conditions caused a large reduction in the evolution of ${ }^{14} \mathrm{CO}_{2}$ indicating that microbial degradation was taking place. The authors postulated that with the change in $\mathrm{pH}$ more metribuzin was available for microbial degradation.

In order to determine the role of $\mathrm{pH}$ on metribuzin dissipation, Ladlie et al. (1976) took soil samples from the $1.12 \mathrm{~kg} / \mathrm{ha}$ treated plots. Samples were taken from the $0-5$, 5-10, and 10-20 depths. As the soil pH decreased the level of extractable metribuzin decreased. Soils at $\mathrm{pH}$ of 6.7 showed greater amounts of extractable residue than soils at $\mathrm{pH}=4.6$. Leaching was also shown to increase as the $\mathrm{pH}$ increased from 4.6 to 6.7 suggesting a decrease in adsorption with increasing $\mathrm{pH}$.

\section{Role of Clay and Organic Matter in Adsorption}

Lafleur (1979) investigated the sorption of metribuzin by agronomic and model soils. Model soils were constructed from sand, alumina, kaolinite, illite, and peat. The agronomic soils investigated were a Norfork loamy sand $(\mathrm{pH}=6.3,79 \%$ sand, $15 \%$ silt, 5\% clay, and $1.15 \%$ organic matter) and a Cecil sandy loam $(\mathrm{pH}=6.1,67 \%$ sand, $20 \%$ silt, $11 \%$ clay, and 
1.9\% organic matter). For the rate studies the sorption times were $1,10,10^{2}, 10^{3}$, and $10^{4}$ minutes. Within the range of 10 to 80 umole of metribuzin/kg, adsorption ratios for inorganic substrates was independent of concentration. Whereas in the agronomic soils or peat containing model soils the adsorption ratios decreased with increasing concentration. In this experiment the samples were shaken for $10^{2}$ minutes.

At 40 umole/kg, sorption by the inorganic soils was independent of time for the range of 1 to $10^{4}$ minutes. Metribuzin sorption for the agronomic soils and peat containing model soils increased with time and equilibrium was not reached in $10^{4}$ minutes. Since adsorption by inorganic components was independent of time, metribuzin adsorption seems to be restricted to the surface sites which are easily accessible. Alumina, with the largest surface, area was the least efficient at adsorption when expressed as umole $/ \mathrm{m}^{2}$. This suggests interlayer sites are not penetrated. Adsorption by peat or organic matter containing agronomic soils was time dependent. The author indicates that this suggests adsorption by organic matter entails adsorption at accessible external sites followed by gradual invasion of the inner sites until equilibrium is established.

Savage (1976) provided evidence for the adsorption and mobility of metribuzin in sixteen different soils ranging from .75 to $4.2 \%$ organic matter. The author used the equation $\mathrm{x} / \mathrm{m}=\mathrm{K}_{1} \mathrm{Ce}+\mathrm{K}_{2} \mathrm{Ce}^{2}$ to describe the sorption equilibrium of metribuzin. In the equation $\mathrm{x} / \mathrm{m}$ represents the mass of 
herbicide adsorbed per unit mass of soil, Ce is the herbicide concentration in equilibrium solution, and $K_{1}$ and $K_{2}$ are constants. Values for $\mathrm{K}_{1}$ which represent the adsorptiondesorption equilibrium constants varied from 0.27 to 3.10 for the soils ranging from 0.75 to 4.28 organic matter. Clay and organic matter contents were positively correlated. The adsorption of ${ }^{14} \mathrm{C}$-metribuzin slightly increased as clay content increased from 0 to $40 \%$. The addition of organic matter alone resulted in much larger increases in adsorption. As the additions of clay increased, the adsorptive capacity of organic matter decreased. The addition of $0 \%$ clay and $1.2 \%$ organic matter resulted in $24 \%$ of metribuzin being adsorbed, however, when $40 \%$ clay was added the amount adsorbed decreased to $15 \%$. This suggests a competition between clay and organic matter may exist for providing adsorptive sites.

Sharom and stephenson (1976) investigated the behavior of metribuzin in 8 different ontario soils. Distribution coefficients ( $K$ values) which describe adsorptive capacity increased as organic matter increased $(r=0.996)$. There was no correlation $(r=0.45)$ of adsorption with clay content. Metribuzin mobility was inversely related to the adsorptive capacity of the soil.

Bouchard et al. (1982) investigated the adsorption of metribuzin and two other herbicides in lab and field studies. 
Two field soils were used, a Taloka silt loam with $\mathrm{pH}=5.2$ and a Roxana silt loam having a pH of 6.8. Both soils had approximately 18 organic matter in the $0-20 \mathrm{~cm}$ depth. Two sampling depths were used, the $0-10 \mathrm{~cm}$ and the $40-50 \mathrm{~cm}$ depth. The two soils did not differ in the adsorption of ${ }^{14} \mathrm{C}$ metribuzin after 24 hours shaking time. The adsorptivity in the $10-20 \mathrm{~cm}$ depth was higher than in the $40-50 \mathrm{~cm}$ depth. This was attributed to higher organic matter levels near the surface.

Lafleur (1980) used soil columns in order that observations of metribuzin movement in soil could be examined. The columns were $1 \mathrm{~m}$ in length and two soil types were used. The Norfold loamy sand $(\mathrm{pH}=6.0,4 \% \mathrm{clay}, 1.3 \% \mathrm{O} . \mathrm{M}$. and $\mathrm{CEC}=$ 6.5) and Cecil sandy loam ( $\mathrm{pH}=6.1$, $11 \% \mathrm{clay}, 2.0 \% 0 . \mathrm{M}$. and CEC = 15). Metribuzin was added to the soil columns at 2.14 $\mathrm{mg} / \mathrm{kg}$ and was allowed to dry for one day. The water was added in $1,2,4,8,16,32,64$, or $128-3 \mathrm{~cm}$ units by drops. Metribuzin followed the wetting front for the 1,2 , and $4-3 \mathrm{~cm}$ units of rain. The Norfold soil after one $3 \mathrm{~cm}$ unit of rain had $22 \pm 6 \%$ in the $20-30 \mathrm{~cm}$ range of the column, whereas the cecil sandy loam had none. After eight $3 \mathrm{~cm}$ rainfalls $54 \%$ of the metribuzin was recovered from the effulent of the Norfold soil column but only $14 \%$ from the Cecil sandy loam column.

Coble and Schrader (1973) considered the relationship between metribuzin rate, organic matter level, rainfall after treatment, and depth of incorporation to soybean injury. Pre-emergence applications of metribuzin were made to pots at 
rates of $0,0.56,1.12$, and $1.68 \mathrm{~kg} / \mathrm{ha}$. The soils used varied from $1.1,3.3,7.8,16.8$, and $40 \%$ organic matter. one-half the pots received rain $(1.25 \mathrm{~cm})$ immediately after treatment and then every 3 days. The other half was not watered for 10 days and then they were watered every 3 days as well. The two planting depths were 1.25 and $2.5 \mathrm{~cm}$. Injury was found to decrease as organic matter levels increased. At $3.3 \%$ organic matter, $1.68 \mathrm{~kg} / \mathrm{ha}$ of metribuzin caused injury which was equivalent to a $0.56 \mathrm{~kg} / \mathrm{ha}$ rate on the soil containing $1.1 \%$ organic matter. The same levels of injury were observed at 3.3 and $7.8 \%$ organic matter. Rainfall after treatment increased the degree of injury. Metribuzin has a solubility of $1220 \mathrm{ppm}$ in water. On the $3.3 \%$ organic matter soil a $1.12 \mathrm{~kg} / \mathrm{ha}$ rate caused $23 \%$ injury with rain, whereas the no rainfall treatment had only $3 \%$ injury. A deeper planting depth on the 3.3 and $7.8 \%$ organic matter soils resulted in less injury at the higher rates of metribuzin.

Factors Influencing Trifluralin Activity in the soil

Role of Organic Matter, $\mathrm{pH}$, and Clay in Adsorption

Hollist and Foy (1971) examined the relationship between surface area, cation exchange capacity, and organic matter as they pertain to trifluralin activity. simulated soils with a sand base containing organic matter, kaolinite, and montmorillonite at 4 rates, $(0,1,10$, and $25 \%$ ) were. 
constructed. Trifluralin was applied at $0,0.1,0.5,1.0$, 2.0 , and $10 \mathrm{ppm}$. $\mathrm{GR}_{50}$ (amount required to get $50 \%$ reduction in growth) values were measured. The $\mathrm{GR}_{50}$ value was determined to be $0.23 \pm .02 \mathrm{ppm}$ in nutrient solution with foxtail millet as the test species. The range of $\mathrm{pH}$ tested was 5.5 to 7.4 and there was no interaction between $\mathrm{pH}$ and herbicide rate. Organic matter was shown to be the major component responsible for reducing phytotoxicity. The effect of both clay minerals was similar. Increasing the clay additives alone did not change the phytotoxicity of trifluralin. $x$-ray diffraction indicated that trifluralin was not able to adsorb to the interlayer surface of montmorillonite. This would support the results of both clays having similar effects on phytotoxicity. Low rates of organic matter and clay seemed to act synergistically in reducing trifluralin phytotoxicity. This may be related to surface area. If organic matter coats the clay particles, the surface area occupied by the organic matter would increase, facilitating greater adsorption.

Grover et al. (1979) conducted experiments to investigate factors affecting adsorption and bioactivity of trifluralin and two other herbicides. The adsorption studies were carried out on five different soils using aqueous solutions of trifluralin containing $0,0.3,0.6$ and $1.0 \mu \mathrm{g} / \mathrm{g}$. The authors used the $K$ value from the Freundich equation, which is a measure of the extent of adsorption, to investigate the effect of a number of soil parameters. A bioassay was also 
performed. Organic matter was found to be most highly correlated with $\mathrm{K}$. Neither $\mathrm{pH}$ or clay content made any significant addition to the correlation with adsorption. Although adsorption increased as $\mathrm{pH}$ decreased, the author attributed this to the high negative correlation between $\mathrm{pH}$ and organic matter and not to any ionic interaction. The $\mathrm{GR}_{50}$ values were positively correlated with organic matter content and $K$. Grover (1974) peformed adsorption studies using a number of different adsorbents. The Freundlich relationship $\log \mathrm{x} / \mathrm{m}$ $=\log \mathrm{K}+\mathrm{n} \log \mathrm{C}$ where $\mathrm{x} / \mathrm{m}=\mathrm{g}$ of herbicide adsorbed/gram of adsorbent, $C=$ equilibrium concentration, $\mathrm{K}=$ value of $\mathrm{x} / \mathrm{m}$ at $C=1$, and $n=$ slope of the isotherm was used to examine the extent of adsorption taking place. Aqueous solutions containing $0.0,0.3,0.6$, and 1.0 ppmw of trifluralin were combined with various adsorbents. Trifluralin was most strongly adsorbed to the hydrophobic adsorbents used such as peat moss or cellulose triacetate, than to the hydrophilic adsorbents such as clay minerals. The value of $\mathrm{K}$ was 1000 for cellulose triacetate and only 35 for montmorillonite. The authors state that molecules having nonpolar regions that are significantly larger than polar regions are likely to adsorb into the hydrophobic region of adsorbent surfaces by means of van der Waals forces and hydrophobic bonding. Trifluralin is non-ionic in nature which suggests that $\mathrm{pH}$ would have a minimal effect. The hydrogen bonding sites of hydrophilic adsorbents are highly hydrated and the herbicide is adsorbed by only van der wals forces. 
Webster et al. (1978) and Prichard and stobbe (1980) provided further evidence for the importance of organic matter in reducing phytotoxicity. Webster et al. (1978) conducted growth room experiments to establish the availability of trifluralin under different soil conditions. The four soils used in this study provided a range of clay contents from 8 to $73 \%$ and organic matter content from 2.9 to 9.28 . Five rates of trifluralin ranging from 0.2 to $3.0 \mathrm{ppm}$ were investigated through the use of a bioassay 0,2 , or 5 weeks after treatment. Oats were the test species. There was little difference between the soils on the basis of total extractable residues. However available phytotoxic residues based on the dry weight reductions in the bioassay did differ significantly. For the period two weeks after treatment, the $E_{50}$ values were $2.6,1.4,1.1$ and $0.6 \mathrm{ppm}$. These values correspond to the Red River clay (O.M. 8.8\%, clay 73\%), Gladstone clay loam (O.M. 9.2\%, clay 34\%), Newdale loam (O.M. $6.8 \%$, clay 26\%) and Almasippi loamy sand (O.M. 2.9\%, clay $8 \%)$

Prichard and stobbe (1980) conducted a bioassay using sorghum and oats as the test species. Concentrations ranging from 0 to 3.0 ppmw were applied to three field soils contained in $200 \mathrm{~mL}$ plastic cups which were kept at F.C. Their results indicated that phytotoxicity was lower in the higher organic matter soils. The $E_{50}$ values using oats were $1.2,1.5$, and 3.4 ppmw of trifluralin for soils ranging from $4.3,6.8$, to $8.3 \%$ organic matter respectively. 


\section{Effect of Moisture and Temperature}

Moyer (1979) examined the effects of organic matter, clay, moisture, and temperature on wild oat control by trifluralin. In the first experiment to evaluate the effect of clay, organic matter, and temperature, wild oats were grown in eleven different soils representing a range of organic matter and clay contents. The temperature regimes were 17 , 22 and $27^{\circ} \mathrm{C}$ with moisture levels being held constant at field capacity. Seven concentrations of trifluralin were used. To examine the effect of moisture and organic matter, four of the soils from the previous study were used. The moisture constants were $0.25,0.75$, and 1.20 of field capacity. Temperature was held constant at $22^{\circ} \mathrm{C}$. The required dose for $90 \%$ control of wild oats was highly dependent on organic matter $(r=.96)$, but not clay content or temperature. In the moisture experiment organic matter accounted for $89 \%$ of the variability and moisture for only an additional $7 \%$. Higher doses were needed at 0.4 and 1.2 field capacity than at 0.8 of field capacity. The author suggested that at low moisture, adsorption is increased, and at high moisture vapor diffusion is reduced because of the reduction in pore space. Also, at saturating conditions the soil is anaerobic and degradation is more rapid.

Anderson et al. (1968) used cylinders filled with a clay loam soil containing $37 \%$ sand, $27 \%$ silt, $36 \%$ clay, and $1 \%$ organic matter with a $\mathrm{pH}=7.8$ to study leaching patterns of 
trifluralin and two other dinitroanilines. Trifluralin was applied to $65 \mathrm{~cm}^{3}$ of soil at a rate of $2.2 \mathrm{~kg} / \mathrm{ha}$ and this soil was added to the top of the columns. Water (1050 mL) was added over a 30 minute period. Through the use of a sorghum bioassay trifluralin was found to a depth of $3.8 \mathrm{~cm}$. The small amount of movement was attributed to a high degree of adsorption and the low water solubility of trifluralin.

\section{Soil Texture and Porosity}

Bode et al. (1973) investigated trifluralin diffusion at moisture contents of $3.1,8.1,13.3,18.4,23.6,28.7$ and $33.9 \% \mathrm{w} / \mathrm{w}$. Temperatures employed were $4.4,16,24,38$, and $49^{\circ} \mathrm{C}$. The two soils used had bulk densities of 1.0 and 1.4 $\mathrm{g} / \mathrm{cm}^{3}$. In the temperature range 4.4 to $49^{\circ} \mathrm{C}$ there was an exponential relationship between temperature and the diffusion coefficients. Diffusion increased as the moisture content went from air dry at $3.1 \%$ to $8.1 \% \mathrm{w} / \mathrm{w}$. Above $8.1 \%$ the increase in moisture resulted in a decreased effect of temperature at increasing the diffusion coefficients. In a previous study Bode demonstrated that vapor diffusion is the major contributor to total diffusion. Thus, as the moisture content is increased, air filled porosity is decreased to a point where eventually it will offset the temperature effect. The same result takes place when the soil is compacted, i.e., increase bulk density from 1.0 to $1.4 \mathrm{~g} / \mathrm{cm}^{3}$. Soil moisture 
has less of an effect at lower bulk densities. When the air filled porosity is reduced below 408 diffusion will decrease with further reductions in porosity regardless of moisture or temperature.

\section{Differential Varietal Tolerance}

As Smith and Wilkinson (1974) indicate, there are numerous reports in the literature of species that differ in crop cultivar response to herbicides. Information on the possibility that fababean cultivars may show differences in response to metribuzin is not available in the current literature. Therefore the evidence to support this possibility will come from the work conducted with soybeans.

\section{Evidence from Field and Greenhouse studies}

Because of the narrow range of soybean tolerance and the large number of cases of soybean injury from metribuzin reported, investigations into the possibility that soybean cultivars may differ in terms of their degree of tolerance to metribuzin were initiated by Hardcastle (1974). In field experiments Hardcastle investigated a number of soybean varieties for their response to pre-emergence applications of metribuzin. 'Coker 102' soybeans were the only variety adversely affected by the treatments. Metribuzin applied at $1.68 \mathrm{~kg} / \mathrm{ha}$ reduced the yield of 'Coker 102' by $41 \%$ of the untreated variety check. All other varieties had higher 
yields with herbicide treatment which is consistent with responses due to the removal of weed competition.

Wax et al. (1976) conducted field experiments on a silt loam containing 3.5-4.5\% organic matter. Metribuzin was applied at $0.56,0.84$, and $1.7 \mathrm{~kg} / \mathrm{ha}$ and incorporated with a tandem disc. A total of 43 soybean varieties and lines were examined for their response to metribuzin. The degree of injury was based on a visual ranking of percent injury. At $0.84 \mathrm{~kg} / \mathrm{ha}$ very dramatic differences in cultivar response was noted. Seven of the cultivars received an injury ranking of $70 \%$ or greater, while fourteen cultivars or lines displayed less than $30 \%$ injury. The injury ratings in this study may have been confounded since all plots received a treatment of trifluralin at $1.1 \mathrm{~kg} / \mathrm{ha}$. Trifluralin has been demonstrated to reduce metribuzin injury to soybeans by Ladiie et al. $(1977)$.

Littlejohns et al. (1977) examined the response of soybean cultivars commonly grown in ontario. Seven cultivars were examined for their response to pre-emergent applications of metribuzin. A number of different parameters were investigated including $\frac{\circ}{\sigma}$ leaf injury, plant stand, plant height, and yield. At $0.56 \mathrm{~kg} / \mathrm{ha}$ of metribuzin $\%$ leaf injury ranged from 4 to $19 \%$ for the different cultivars. Metribuzin at a higher rate of $0.84 \mathrm{~kg} / \mathrm{ha}$ resulted in a differential response for plant stand and plant height for the cultivars examined. However, under the conditions of this experiment yield did not differ significantly between the cultivars. 
Barrentine et al. (1982) were interested in comparing Tracy-M, a new variety, to its parent selection Tracy and to another cultivar, Centennial. Tracy has been previously classed by Barrentine et al. (1976) as a susceptible cultivar. In 1978, metribuzin applied PPI at $1.1 \mathrm{~kg} / \mathrm{ha}$ resulted in twice as much injury to Tracy as it did to Tracy-M or centennial. In 1979 the injury was greater, with $0.6 \mathrm{~kg} / \mathrm{ha}$ of metribuzin causing $40 \%$ injury to Tracy. In order to get the same level of injury in Tracy-M or Centennial, metribuzin was required at 0.8 and $1.1 \mathrm{~kg} / \mathrm{ha}$, respectively. In 1979 the yield of the three cultivars receiving metribuzin at 0.6 $\mathrm{kg} / \mathrm{ha}$ were 450,1490 and $2640 \mathrm{~kg} / \mathrm{ha}$ for Tracy, Tracy-M, and Centennial respectively. Higher levels of injury in 1979 than in 1978 were attributed to different planting dates and rainfall patterns. In 1978 planting after metribuzin application was delayed 20 days, and during that period $24 \mathrm{~cm}$ of rain was received. In 1979 planting took place 1 day after metribuzin application.

Eastin et al. (1980) investigated the response of sixteen determinate soybean genotypes in a greenhouse study using a Morey silt loam containing $2.1 \%$ organic matter. The responses of some of the cultivars were already known, but these were included as standards for comparison. The other eight cultivars had not been previously classed as to their tolerance to metribuzin. At a rate of $0.6 \mathrm{~kg} / \mathrm{ha}$ a differential response could be detected. Based on visual ratings, 
with 0 being no injury and 100 being complete kill, a wide response was noted. The cultivars Forrest and Davies received ratings of 22 , whereas the cultivars semmes and Tracy received ratings of 52 and 55 respectively.

\section{Hydroponic Studies}

Comparison of injury levels and rankings of different cultivars in terms of their response to metribuzin between field experiments themselves, and between field and greenhouse experiments is difficult. Coble and Schrader (1973) indicated that injury from metribuzin treatment can be influenced by soil organic mattér levels, soil pH, and rainfall patterns after treatment. Variations in these parameters may make cultivar differences in tolerance difficult to assess. In order to circumvent this problem, a number of investigators have used hydroponic systems to evaluate cultivars for differential tolerance to metribuzin.

Barrentine et al. (1976) described a hydroponic system for screening soybean cultivars for metribuzin tolerance. In their experiment the response of 45 soybean cultivars was investigated. Pre-germinated plants were allowed to grow in a modified Hoagland's solution until the first trifoliate leaves were expanded. At that time, 0.125 ppm of metribuzin was added to the nutrient solution. Visual ratings were performed ten days later. The response ranged from slight injury with the cultivar 'Wayne' to complete necrosis in the case of the cultivars 'Semmes' and 'Tracy'. 
Hardcastle (1979) used essentially the same hydroponic screening system as Barrentine et al. (1976) had used, but he expressed injury on a total dry weight basis. Twenty-eight cultivars were investigated and each of the maturity classes examined had tolerant and susceptible cultivars. The response ranged from $101 \%$ of the control for the most tolerant variety to $61 \%$ for 'Bragg', to $40 \%$ of the control for 'Semmes'.

Barrentine et al. (1982) continued their work using nutrient culture and compared the cultivar 'Tracy' to two new cultivars. The plants were visually rated and the data was subjected to probit analysis and the relative $I_{50}$ (50\% injury) concentrations were calculated. It was determined that the $I_{50}$ concentration for 'Tracy-M' and Centennial was approximately three times as high as that for 'Tracy'.

\section{Possible Mechanism for Differential Tolerance}

Smith and Wilkinson (1974) carried out a series of experiments in an attempt to discern the basis of differential tolerance in soybeans. Of the three cultivars investigated, 'Bragg' is classed as a tolerant cultivar, whereas 'Semmes' and 'Coker 102' are classed as susceptible soybean cultivars. Seedlings growing in sand were subirrigated with nutrient solution. Labelled metribuzin was added to the solution when the seedlings were two weeks old. Autoradiographs were prepared 24, 48, and 96 hours after treatment. 
After a three week exposure period, the plants were sectioned into leaflets, stems (including petioles), and roots. The tissue was then ground and the samples were extracted and prepared for thin layer chromatography.

When the autoradiographs were examined it was observed that within 24 hours after treatment there was movement and distribution throughout the stems and leaves of 'semmes' and 'Coker 102'. The activity in 'Bragg' was restricted to the stem and leaf veins. Quantifying the levels of radioactivity revealed that the leaves of 'semmes' and 'Coker 102' contained three and four times respectively, the amount of radioactivity compared to 'Bragg' leaves twenty-four hours after treatment. This difference was hypothesized to be due to a greater percentage of radioactivity in the form of metaboIites in 'Bragg' stems and roots. The stem contained $95 \%$ of the radioactivity in the form of metabolites and the roots contained 76\%. This compares to $70 \%$ for 'Semmes' and 'Coker $102^{\prime}$ 'stems, and $26 \%$ and $36 \%$ for 'Semmes' and 'Coker 102' roots respectively. This same pattern of a greater percentage of metabolites being present in 'Bragg' plants was evident for the 48 and 96 hour sampling as well.

Hargroder and Rogers (1974) reporting the results of Thorton and Schuman (1972), stated that metabolites could be separated from metribuzin by solvent partitioning because they are quite different in polarity. Thin layer chromatography of the extracts of the stem sections of the three 
cultivars used by Smith and Wilkinson (1974) indicated that different metabolites were being formed in the tolerant and susceptible cultivars. In 'Bragg' the majority of the metabolites were found to be in the Rf range of $0.30-0.45$, whereas the susceptible cultivars had the majority of metabolites in the Rf range $0.60-0.75$. Subsequent TLC indicated that in the Rf range $0.60-0.75,88 \%$ of the radioactivity present was due to the metabolite DADK[6-tert-butyl-as-triazine-3-5(2H, 4H)-dione], which forms as a result of both a deamination and demethylthiolation of metribuzin.

Mangoet et al. (1979) provided further information on differential metabolism between soybean cultivars. They conducted experiments similar to those of Smith and Wilkinson (1974) using the susceptible cultivar 'Coker 102' and the tolerant cultivar 'Essex'. Plants treated with ${ }^{14} \mathrm{C}$ metribuzin were sectioned into stems and roots. The plants were diced, homogenized, and the tissue was extracted using chloroform and distilled water. The chloroform and aqueous fractions were separated further using thin layer chromatography, and the amount of radioactivity in the elution area was determined. The concentration of metabolites was expressed in terms of metribuzin equivalents, i.e., the concentration that would be present if the ${ }^{14} \mathrm{C}$ remained as ${ }^{14} \mathrm{C}$ - metribuzin.

The shoots of 'Coker 102' were found to contain more metribuzin equivalents than 'Essex'. The chloroform fraction 
was examined further and quantified through TLC with known standards. In addition to metribuzin and DADK, two other compounds identified as DA and DK were present. DA[6-tertbutyl-3-(methylthio)-as-triazin-5(4H)-one] is formed as a result of the deamination of metribuzin. DK[4-amino-6-tertbutyl-as-triazin-3,5(2H,4H)dione] is formed as a result of the demethythiolation of metribuzin. The levels of DADK or DA did not differ in the two cultivars, however the level of DK was significantly higher in 'Coker 102' shoots. These results are similar to those of Smith and Wilkinson (1974) in that the levels of DADK are the same in both tolerant and susceptible cultivars. However, Smith and Wilkinson made no mention of either DA or DK. The results also agree in that the tolerant plants always have higher levels of metabolites, especially polar ones, isolated from the aqueous fractions.

Swanson et al. (1966) investigated the formation of N-glucosyl complexes from amiben (3-amino-2,5-dichlorobenzoic acid). Frear et al. (1967) was able to demonstrate that amiben was conjugated with glucose in soybeans to form the $\mathrm{N}-\mathrm{glucosy}$. of amiben called [N-(3-carboxy-2,5-dichlorophenyl)-glucosyl-amine]. Frear (1968) was able to purify a soluble enzyme UDP-glucose:arylamine N-glucosyl-transferase that was able to carry out the conjugation.

Preliminary evidence that this may occur with metribuzin came from Smith and Wilkinson (1974). The tolerant cultivars had the majority of the radioactivity present in the Rf range 
of 0.30-0.45 when TLC was performed. When this metabolite was cochromatographed with the N-glucoside of amiben, similar Rf values were obtained. Also the hydrolysis of the metabolite yielded glucose. 


\section{MATERIALS AND METHODS}

\section{$\underline{\text { Field Trials }}$}

\section{Field Sites}

In the spring of 1981 and 1982 field trials were initiated at the University of Manitoba and the Glenlea Research Station, respectively. The soil at the University site was an Osborne clay and consisted of $2 \%$ sand, $34 \%$ silt, $64 \%$ clay, and had a pH of 7.8. The Glenlea soil was an Osborne clay which contained $4 \%$ sand, $25 \%$ silt, $71 \%$ clay, and had a pH of 6.5. The organic matter content of the two soils was 4.8 and $5.7 \%$ at the University and Glenlea, respectively. A soil test was performed at the Manitoba soil Testing Lab for available N, P, K, and S (see Table l) for the two soils.

\section{Experimental Design}

The trials were arranged in a randomized complete block design. In 1981 the experiment consisted of sixteen treatments, with each treatment being replicated three times. Individual plot size was $1.2 \times 5.5 \mathrm{~m}$. Treatments included a hand weeded control, trifluralin EC $(400 \mathrm{~g} / \mathrm{L}$ a.i.) at 1.1 $\mathrm{kg} / \mathrm{ha}$, metribuzin $(500 \mathrm{~g} / \mathrm{L} \mathrm{a.i.)} \mathrm{at} 0.42 \mathrm{~kg} / \mathrm{ha}$, and a tank mix of trifluralin EC and metribuzin at $1.1 \mathrm{~kg} / \mathrm{ha}$ and 0.42 $\mathrm{kg} / \mathrm{ha}$, respectively. Each herbicide or tank mix combination was applied alone or in combination with fertilizer, rhizobia, or both fertilizer and rhizobia. The fertilizer, 
TABLE 1. Available nutrients of field soils at the two
sites.

\begin{tabular}{|c|c|c|c|c|c|c|c|}
\hline \multirow[b]{2}{*}{ Field Site } & \multirow{2}{*}{$\begin{array}{c}\text { Depth } \\
\mathrm{cm} \\
\end{array}$} & \multicolumn{2}{|c|}{ Nitrate-Nitrogen } & \multicolumn{2}{|c|}{$\begin{array}{l}\text { Available } \\
\text { Phosphorus }\end{array}$} & \multicolumn{2}{|c|}{$\begin{array}{l}\text { Available } \\
\text { Potassium }\end{array}$} \\
\hline & & $\mathrm{ppm}$ & $\mathrm{kg} / \mathrm{ha}$ & $\mathrm{ppm}$ & $\mathrm{kg} / \mathrm{ha}$ & $\mathrm{ppm}$ & $\mathrm{kg} / \mathrm{ha}$ \\
\hline \multicolumn{8}{|l|}{$\begin{array}{l}\text { University } \\
\text { of }\end{array}$} \\
\hline Manitoba & $0-15$ & 17.0 & 30.6 & 34.9 & 62.8 & 629 & 1133 \\
\hline Glenlea & $0-15$ & 33.8 & 60.8 & 25.4 & 45.7 & 625 & 1125 \\
\hline
\end{tabular}


rhizobia, and fertilizer and rhizobia treatments were applied without herbicide as well (see Table 2).

In both 1981 and 1982 the inoculum used was soil implant inoculum from the Nitragin company applied with the seed. The rate applied was $5.6 \mathrm{~kg} / \mathrm{ha}$ which is the recommended dosage.

In 1982 the experiment consisted of fourteen treatments, replicated four times. Individual plot size was $2.44 \mathrm{~m} \mathrm{x}$ $5.50 \mathrm{~m}$. The treatments included three controls, an inoculated control, an uninoculated control, and a barley control. The uninoculated control and the barley control were included to obtain an estimate of total available soil nitrogen. Herbicide treatments included trifluralin EC $(545 \mathrm{~g} / \mathrm{L}$ a.i.) at 0.82 and $1.1 \mathrm{~kg} / \mathrm{ha}$, metribuzin $(500 \mathrm{~g} / \mathrm{L}$ a.i.) at $0.2,0.4$, and $0.6 \mathrm{~kg} / \mathrm{ha}$. All possible trifluralin and metribuzin combinations were also applied. All the plots except the uninoculated controls were inoculated (see Table 3). In 1981 and 1982 all plots were hand weeded.

\section{Fertilizer and Herbicide Application}

In 1981 ammonium nitrate fertilizer (34-0-0) was broadcast using a Gandy fertilizer spreader. The fertilized plots received $147 \mathrm{~kg} / \mathrm{ha}$. All herbicide treatments were applied using a bicycle-wheel sprayer equipped with Teejet 80015 flat-fan nozzles. Application was made May 11, 1981 and May 20, 1982 and the treatments were immediately incorporated with a power driven rotary tiller set to operate to a depth 
TABLE 2. Treatment 1ist for 1981 field experiment

Treatment

1 Contro1 (Uninoculated)

2 Fertilizer ( $147 \mathrm{~kg} /$ ha of $34-0-0)$

3 Trifluralin ( $400 \mathrm{~g} / \mathrm{L} \mathrm{a.i.)} \mathrm{at} 1.1 \mathrm{~kg} / \mathrm{ha}$

4 Metribuzin ( $500 \mathrm{~g} / \mathrm{L} \mathrm{a.i.)} \mathrm{at} 0.42 \mathrm{~kg} / \mathrm{ha}$

5 Trifluralin $(1.1 \mathrm{~kg} / \mathrm{ha})+$ Metribuzin at $0.42 \mathrm{~kg} / \mathrm{ha}$

6 Trifluralin $(1.1 \mathrm{~kg} / \mathrm{ha})+$ Fertilizer

7 Metribuzin $(0.42 \mathrm{~kg} / \mathrm{ha})+$ Fertilizer

8 Trifluralin $(1.1 \mathrm{~kg} / \mathrm{ha})+$ Metribuzin $(0.42 \mathrm{~kg} / \mathrm{ha})+$ Fertilizer

9 Control (Inoculated with Rhizobia)

10 Trifluralin ( $1.1 \mathrm{~kg} / \mathrm{ha})+$ Rhizobia

11 Metribuzin $(0.42 \mathrm{~kg} / \mathrm{ha})+$ Rhizobia

12 Trifluralin $(1.1 \mathrm{~kg} / \mathrm{ha})+$ Metribuzin $(0.42 \mathrm{~kg} / \mathrm{ha})+$ Rhizobia

13 Fertilizer + Rhizobia

14 Trifluralin $(1.1 \mathrm{~kg} / \mathrm{ha})+$ Fertilizer + Rhizobia

15 Metribuzin $(0.42 \mathrm{~kg} / \mathrm{ha})+$ Fertilizer + Rhizobia

16 Trifluralin $(1.1 \mathrm{~kg} / \mathrm{ha})+$ Metribuzin $(0.42 \mathrm{~kg} / \mathrm{ha})+$ Fertilizer + Rhizobia

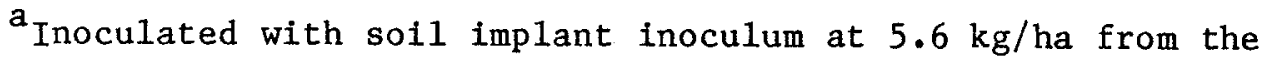
Nitragin Company, Milwaukee, Wisconsin. 
TABLE 3. Treatment list for 1982 field experiment

\begin{aligned} & \hline Treatment \\ & 1 Inoculated Control \\ & 2 Uninoculated Control \\ & 3 Trifluralin $(545 \mathrm{~g} / \mathrm{L} \mathrm{a.i.)} \mathrm{at} 0.8 \mathrm{~kg} / \mathrm{ha} \\ & 4$ Trifluralin $(545 \mathrm{~g} / \mathrm{L}$ a.i. $)$ at $1.1 \mathrm{~kg} / \mathrm{ha} \\ & 5$ Metribuzin $(500 \mathrm{~g} / \mathrm{L} \mathrm{a.i.)} \mathrm{at} 0.2 \mathrm{~kg} / \mathrm{ha} \\ & 6$ Metribuzin $(500 \mathrm{~g} / \mathrm{L} \mathrm{a.i.)} \mathrm{at} 0.4 \mathrm{~kg} / \mathrm{ha} \\ & 7$ Metribuzin $(500 \mathrm{~g} / \mathrm{L} \mathrm{a.i.)} \mathrm{at} 0.6 \mathrm{~kg} / \mathrm{ha} \\ & 8$ Trifluralin $(0.8 \mathrm{~kg} / \mathrm{ha})+$ Metribuzin $(0.2 \mathrm{~kg} / \mathrm{ha}) \\ & 9$ Trifluralin $(0.8 \mathrm{~kg} / \mathrm{ha})+$ Metribuzin $(0.4 \mathrm{~kg} / \mathrm{ha}) \\ & 10$ Trifluralin $(0.8 \mathrm{~kg} / \mathrm{ha})+$ Metribuzin $(1.6 \mathrm{~kg} / \mathrm{ha}) \\ & 11$ Trifluralin $(1.1 \mathrm{~kg} / \mathrm{ha})+$ Metribuzin $(0.2 \mathrm{~kg} / \mathrm{ha}) \\ & 12$ Trifluralin $(1.1 \mathrm{~kg} / \mathrm{ha})+$ Metribuzin $(0.4 \mathrm{~kg} / \mathrm{ha}) \\ & 13$ Trifluralin $(1.1 \mathrm{~kg} / \mathrm{ha})+$ Metribuzin $(1.6 \mathrm{~kg} / \mathrm{ha}) \\ & 14$ Barley Control \\ & \hline\end{aligned}

anoculated contro1 and treatments 3-13 received soil imp1ant inoculum at $5.6 \mathrm{~kg} / \mathrm{ha}$. Source of inoculum was the Nitragen Company, Milwaukee, Wisconsin. 
of $10 \mathrm{~cm}$. The sprayer delivered $108 \mathrm{~L} / \mathrm{ha}$ and $120 \mathrm{~L} / \mathrm{ha}$ in 1981 and 1982, respectively, and was operated at $275 \mathrm{KPa}$. The experiments were seeded on May 13, 1981 and May 21, 1982 with fababeans, variety Hertz freya, to a depth of $6 \mathrm{~cm}$ at a rate of $200 \mathrm{~kg} / \mathrm{ha}$. A four-row double disc plot seeder was used and the discs were set. $305 \mathrm{~m}$ apart.

\section{Sampling Methods}

Sampling throughout the growing season was conducted three times in 1981 and five times in 1982. The sampling dates in 1981 were July 4, July 24, and August 10. In 1982 the dates were June 22, July 8, July 19, August 3, and August 17. The variables examined at these sampling dates were fresh and dry weights of above ground portions, nodule dry weights, nitrogenase activity, and $\frac{\circ}{\circ}$ protein. For fresh and dry weights of above ground portions the sampling technique varied between 1981 and 1982. In 1981, three plants per plot were randomly selected, and in 1982 a random $0.5 \mathrm{~m}$ sample per plot was taken. These plants were bagged and kept on ice until they were returned to the lab where fresh weights were measured immediately. Dry weights were measured after the plants were dried at $100^{\circ} \mathrm{C}$ in a forced hot-air oven for 48 hours. The dried samples were ground and a Kjeldahl analysis was performed to determine 8 protein.

\section{Nitrogenase Activity Measurements}

The nitrogenase activity was determined by using the acetylene reduction technique established by Hardy et al. 
(1968). A modification of the procedure used by Candlish and Clark (1975) was followed. The plants removed for fresh and dry weight determinations at each sampling date were used for performing the acetylene reduction assay. The soil was carefully removed from the roots and the shoots were separated from the roots at the soil surface. The jars used for the assay were $800 \mathrm{~mL}$ Mason jars. The lids of the jars were fitted with rubber stoppers for serum bottles. The jars were buried in the soil at the field site to a depth parallel to the lids. The roots were placed in the jars and $15 \mathrm{~mL}$ of acetylene was injected into each jar using a $40 \mathrm{~mL}$ B-D Plastipak syringe. After a 30 minute period a $10 \mathrm{~mL}$ sample was withdrawn from each jar and injected into sterile vacutainer tubes (Becton Dickinson) until analysis was performed in the lab. In 1982 the same procedure was followed except that only five of the plants that were removed for the $0.5 \mathrm{~m}$ sample were used for the acetylene reduction assay.

After the acetylene reduction assay was performed the roots were bagged, and placed on ice until field sampling was complete. In the lab the nodules were carefully picked off the roots and dried at $80^{\circ} \mathrm{C}$ for 48 hours and then weighed. In 1982, three of the five roots used for the acetylene reduction assay were selected at random and used to assess nodule weights.

Measurement of the ethylene produced during the acetylene reduction assay was determined by analyzing $0.3 \mathrm{~mL}$ and $0.1 \mathrm{~mL}$ samples from the vacutainers in 1981 and 1982 respectively on a gas chromatograph. The samples were analyzed on 
a Carle TM Analytical Gas Chromatograph fitted with a hydrogen flame ionization detector. The column was $304 \mathrm{~cm}$ long and $0.2 \mathrm{~cm}$ in diameter, and was packed with 50-80 mesh Porapak Type $\mathrm{T}$. The column temperature was $70^{\circ} \mathrm{C}$ with injection port and detector temperature of 76 and $74^{\circ} \mathrm{C}$ respectively. Helium was used as the carrier gas and retention times were 1.5 and 3.0 minutes for ethylene and acetylene, respectively.

\section{Yield Measurements}

Final seed yield was determined by hand harvesting 5.03 $m$ of the center two rows of each plot in 1981 and the center four rows of each plot in 1982. The samples were threshed using a Vogel stationary thresher. Plot yields, once the seed was cleaned, were expressed on a $\mathrm{kg} / \mathrm{ha}$ basis.

\section{Growth Room Experiment}

An experiment to study the effect of two soil applied herbicides on shoot and root growth was initiated in a growth room on October 11, 1982. The same study was repeated on January 15, 1983. The plots were arranged in a randomized complete block design consisting of nine treatments replicated four times each. The treatments included a control, trifluralin EC at 0.8 and $1.1 \mathrm{~kg} / \mathrm{ha}$, metribuzin at 0.25 and 0.42 $\mathrm{kg} / \mathrm{ha}$, and all possible combinations of trifluralin and metribuzin (see Table 4).

The field soil from the previously mentioned Glenlea site was used in this experiment. The pots were made from PVC sewer pipe cut in $33 \mathrm{~cm}$ lengths. The pot dimensions were 
TABLE 4. Treatment list for growth room experiment.

Treatment

1 Control

2 Trifluralin ( $545 \mathrm{~g} / \mathrm{L} \mathrm{a.i.)} \mathrm{at} 0.8 \mathrm{~kg} / \mathrm{ha}$

3 Trifluralin ( $545 \mathrm{~g} / \mathrm{L} \mathrm{a.i.)} \mathrm{at} 1.1 \mathrm{~kg} / \mathrm{ha}$

4 Metribuzin ( $500 \mathrm{~g} / \mathrm{L} \mathrm{a.i.)} \mathrm{at} 0.25 \mathrm{~kg} / \mathrm{ha}$

5 Metribuzin ( $500 \mathrm{~g} / \mathrm{L} \mathrm{a.i.)} \mathrm{at} 0.42 \mathrm{~kg} / \mathrm{ha}$

6 Trifluralin $(0.8 \mathrm{~kg} / \mathrm{ha})+$ Metribuzin $(0.25 \mathrm{~kg} / \mathrm{ha})$

7 Trifluralin $(0.8 \mathrm{~kg} / \mathrm{ha})+$ Metribuzin $(0.42 \mathrm{~kg} / \mathrm{ha})$

8 Trifluralin $(1.1 \mathrm{~kg} / \mathrm{ha})+$ Metribuzin $(0.25 \mathrm{~kg} / \mathrm{ha})$

9 Trifluralin $(1.1 \mathrm{~kg} / \mathrm{ha})+$ Metribuzin $(0.42 \mathrm{~kg} / \mathrm{ha})$ 
$10 \mathrm{~cm} \times 33 \mathrm{~cm}$. Untreated soil was added to the bottom $20 \mathrm{~cm}$ of each pot. The treated layer of soil occupied the upper upper $10 \mathrm{~cm}$ of each pot so that a soil column $30 \mathrm{~cm}$ in length was formed. The soil was treated by placing the proper weight of soil for each treatment in a rotary mixer and slowiy spraying on the respective rate of herbicide in $100 \mathrm{~mL}$ of $\mathrm{H}_{2}{ }^{0}$ from an atomizer. The final concentrations after mixing were 0.8 and $1.1 \mathrm{ppm}$ of trifluralin and 0.3 and 0.45 ppm metribuzin.

Four seeds were planted per pot and were thinned to one plant per pot after emergence. The pots were maintained between 75 and $100 \%$ field capacity by weighing the pots and adding water every two-three days. In the initial experiment the plants were grown under an 16 hour photoperiod with a $23^{\circ} \mathrm{C} / 16^{\circ} \mathrm{C}$ day/night temperature regime. The average light intensity over the entire bench was $282 \mu^{-2}$ sec $^{-1}$. In the second experiment the plants were grown in a 16 hour photoperiod with a day/night temperature regime of $23^{\circ} \mathrm{C} / 15^{\circ} \mathrm{C}$. The average light intensity was $240 \mu \mathrm{Em}^{-2} \mathrm{sec}^{-1}$.

Sampling time was 1,3 , and 5 weeks after emergence for the initial experiment, and 2,4 , and 6 weeks after emergence when the study was repeated. Fresh and dry weights of shoots were measured, with dry weights being recorded after drying the plants at $80^{\circ} \mathrm{C}$ for 48 hours. The roots were divided into three sections: $0-10 \mathrm{~cm}$ depth, 10-20 cm, and 20-30 cm depth. Total root length was measured for each section by the modified line intersect method reported by Tennant (1975). Root dry weights for each section were also measured by drying at $80^{\circ} \mathrm{C}$ for 48 hours. 


\section{Hydroponic Experiment}

Six different fababean varieties and lines were investigated for possible differences in tolerance to the herbicide metribuzin. The varieties investigated were Hertz freya, outlook, and Aladin. The three lines examined were two University of Manitoba selections: $80 \mathrm{FUMI}$ and $80 \mathrm{FUM} 3$ and the third was seed selected from Hertz freya plants that seemed to show greater tolerance towards metribuzin in a field study conducted in 1981 .

The hydroponic system that was used was similar to those described by Barrentine et al. (1976) and Hardcastle (1979). wooden tanks $70.0 \mathrm{~cm} \times 35.5 \mathrm{~cm} \times 30.5 \mathrm{~cm}$ lined with polyethylene plastic were filled with 60 liters of a modified Hoagland's solution similar to that reported by Barrentine et al. (1976). The nutrients used on a per-liter basis were 2.5 $\mathrm{mL}$ of $1 \mathrm{M} \mathrm{KNO}_{3}, 2.5 \mathrm{~mL}$ of $1 \mathrm{M} \mathrm{CA}\left(\mathrm{NO}_{3}\right)_{2}, 0.5 \mathrm{~mL}$ of $1 \mathrm{M}$ $\mathrm{KH}_{2} \mathrm{PO}_{4}$ and $1.0 \mathrm{~mL}$ of $1 \mathrm{M} \mathrm{MgSO}_{4} \cdot$

The micronutrients were added at a rate of $0.5 \mathrm{~mL} / 1$ iter from a one-liter stock solution containing $7.0 \mathrm{~g} \mathrm{MnCl}_{2} \cdot 4 \mathrm{H}_{2} \mathrm{O}$, $11.0 \mathrm{~g} \quad \mathrm{H}_{3} \mathrm{BO}_{3}, 1.0 \mathrm{~g} \quad \mathrm{ZnSO}_{4}, 1.0 \mathrm{~g} \quad \mathrm{CUSO}_{4} \cdot 5 \mathrm{H}_{2} 0,1.0 \mathrm{~g}$ $\mathrm{Co}\left(\mathrm{NO}_{3}\right)_{2} \cdot 6 \mathrm{H}_{2} \mathrm{O}$ and $0.24 \quad \mathrm{~g} \quad \mathrm{Na}_{2} \mathrm{MOO}_{4} \cdot 2 \mathrm{H}_{2} 0$. Iron was added at a rate of $1 \mathrm{~mL} /$ liter from a stock solution containing $24.8 \mathrm{~g}$ of ferrous sulfate. The nutrient solution was made up using distilled water and it was kept at a pH=6.0 throughout the experiment. The nutrient solution was aerated. 
Fababean seeds of each variety or line were pregerminated in vermiculite. The plants were transferred to the nutrient solution before the first true leaves expanded. The seedlings were placed in holes in a polystyrene sheet that was fitted to each tank. The holes were $5.0 \mathrm{~cm}$ apart and the plants were arranged in a completely randomized design with twenty-one plants of each variety being investigated. Foam plugs fitted to the holes provided additional support for the seedlings. Two identical tanks were used. When the first two true leaves were fully expanded, metribuzin at a rate of $0.125 \mathrm{ppm}(\mathrm{v} / \mathrm{v})$ was added to one tank. The other tank served as a control.

The plants were grown in a growth room under a 16-hour photoperiod with a day/night temperature regime of $23^{\circ} \mathrm{C} / 15^{\circ} \mathrm{C}$. The average light intensity over the entire bench was $340 \mu \mathrm{Em}^{-2} \sec ^{-1}$. The seedlings were transfered to the tanks on March 17, 1983. The herbicide was added March 20, 1983 and the experiment was terminated on March 28, 1983 when the most susceptible plants were dead. Fresh weights were measured, and the plants were dried for 48 hours at $80^{\circ} \mathrm{C}$ and dry weights were also measured. This was done for both the treated and control plants. The differences in tolerance were examined by expressing the herbicide effect on the treated plants on a percent of control basis. 
Experimental Analysis

Data collected from both field trials, along with data gathered from growth room and hydroponic studies was analyzed in a similar fashion. Firstly, the data was subjected to an analysis of variance. Further tests were conducted where F-tests indicated significant differences between means. All statistical tests were conducted at the 5\% level of significance. Multiple comparisons were made using the Duncan's Multiple Range Test. Pairwise comparisons were made using the Least Significant Difference (LSD) method. 


\section{RESULTS AND DISCUSSION}

\section{Field study}

\section{Herbicide Effects on Vegetative Growth}

During 1981 necrotic areas developed at the tips and edges of leaves of plants treated with the $0.42 \mathrm{~kg} / \mathrm{ha}$ rate of metribuzin. These same injury symptoms were evident in 1982 , and were more pronounced at the $0.6 \mathrm{~kg} / \mathrm{ha}$ rate than the 0.4 $\mathrm{kg} / \mathrm{ha}$ application. As reported by Ashton and Crafts (1981), the development of chlorotic and necrotic areas at the tips and edges of the leaves is characteristic of the apoplastic translocation of the triazines.

The injury resulting from metribuzin application was extremely severe in 1981 (Eigures $1 \mathrm{a}$ and $2 \mathrm{a}$ ). Almost all plants displayed injury symptoms consisting of blackened necrotic areas, but in many cases complete necrosis occurred, significantly reducing the plant population. Those plants that did recover were extremely stunted and had weak spindly stems.

Although the plots that received the tank mix treatment of trifluralin and metribuzin at 1.1 and $0.42 \mathrm{~kg} / \mathrm{ha}$ respectively, had plants that displayed injury symptoms, the herbicide treatment was not as phytotoxic as metribuzin applied alone. The plants were generally stunted, although not as severely as in the metribuzin treated plots. Stand reduction was similar for both treatments (Table 14 Appendix). Metribuzin applied alone at $0.4 \mathrm{~kg} / \mathrm{ha}$ and the tank mix caused a 


\section{5


Figure 1. Influence of herbicide application on shoot growth plant parts for the resh weight of above ground $\mathrm{RH}=$ Inoculated the years (A) 1981 and (B) 1982. Inoculum; $\mathrm{T}+\mathrm{M}+\mathrm{RH}=\mathrm{Control;} \mathrm{T}+\mathrm{RH}=$ Trifluralin and Inoculum; $M+R H=$ Metribuzin and and Metribuzin and 

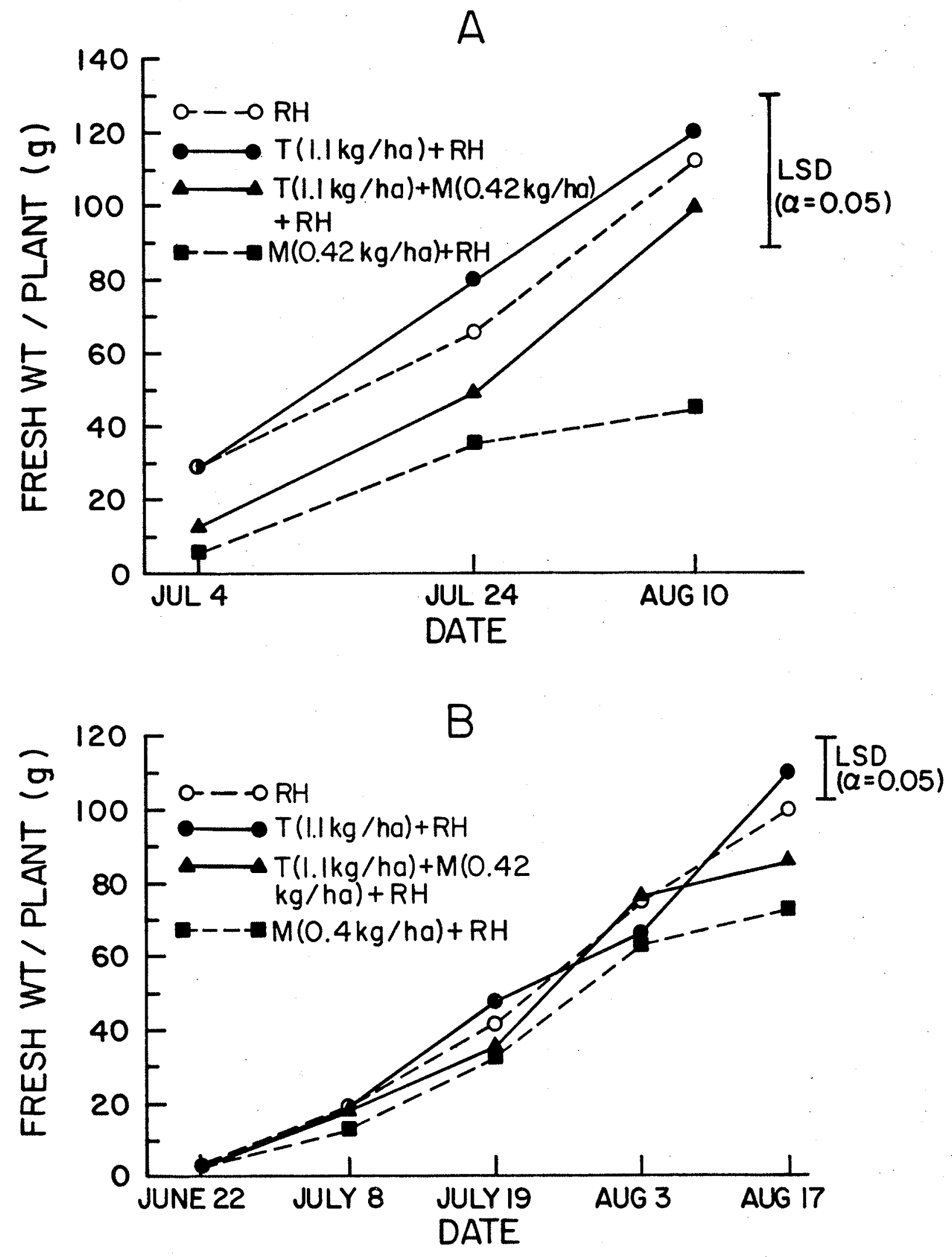
Figure 2. Influence of herbicide application on shoot growth as represented by the dry weight of above ground plant parts for the years (A) 1981 and (B) 1982 . $\mathrm{RH}=$ Inoculated control; $\mathrm{T}+\mathrm{RH}=$ Trifluralin and Inoculum; $\mathrm{T}+\mathrm{M}+\mathrm{RH}=$ Triflural in and Metribuzin and Inoculum; $M+R H=$ Metribuzin and Inoculum. 

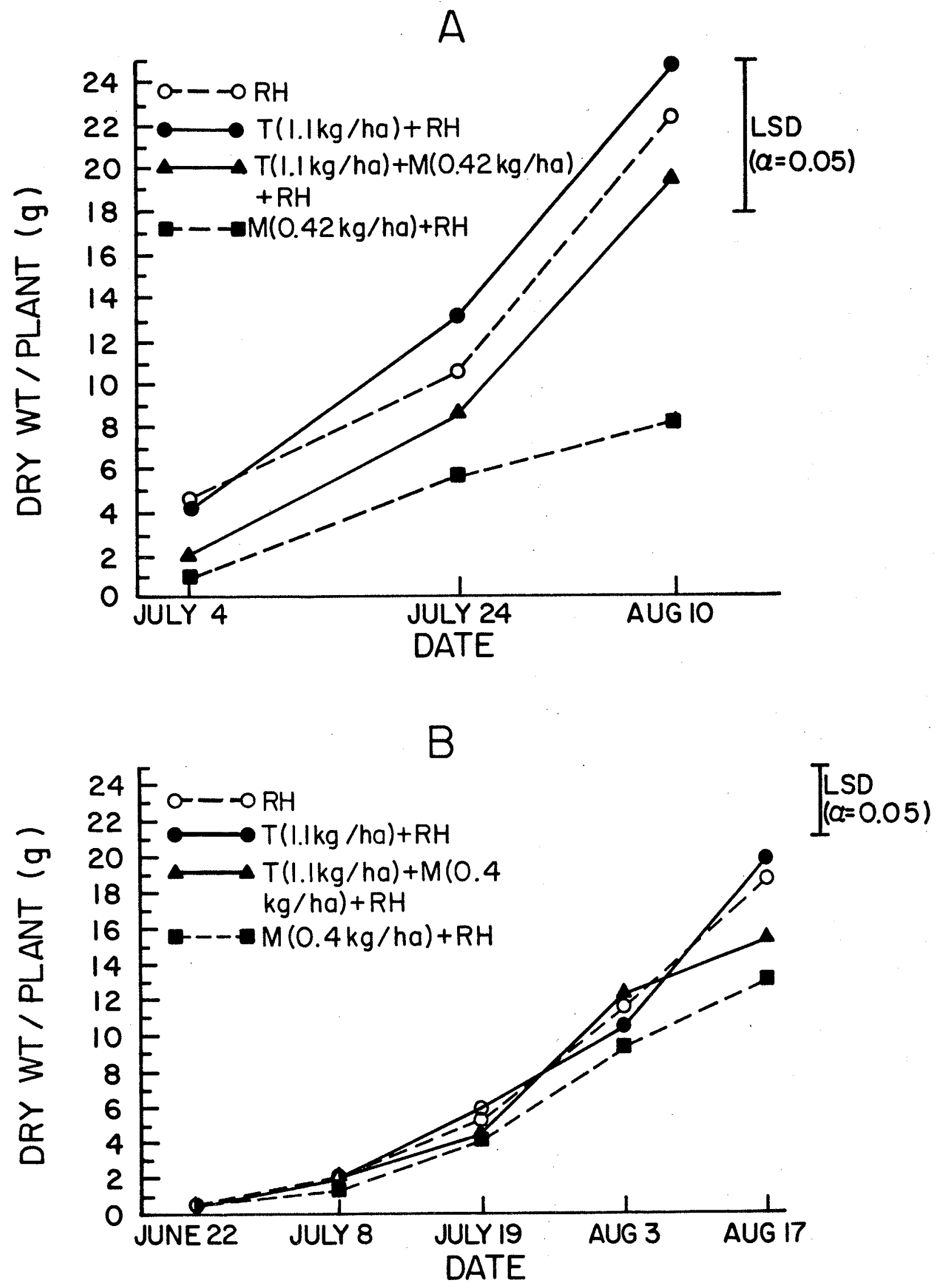
23.3 and $22.5 \%$ stand reduction, respectively. However, at the last sampling date of August 10 the fresh and dry weight, expressed on a per plant basis, of the tank mix was 89 and 78.3\% of the inoculated control respectively. Whereas, the Eresh and dry weight of plants treated only with metribuzin was 40.4 and $41.7 \%$ of the inoculated control respectively (see also Tables 1 and 2 in the Appendix).

In 1981 trifluralin, metribuzin, and the tank mix were applied alone, with rhizobia, with fertilizer, and with a fertilizer and rhizobia combination. There was also an uninoculated control. Crop injury was the same for each herbicide application regardless of whether or not the plants were inoculated. The plants that were not inoculated had nodules and were fixing nitrogen as a result of infection by resident surviving rhizobia from previous crop production. Therefore all the uninoculated controls are useless in terms of comparison to inoculated treatments. Thus, emphasis will be on the herbicide treatments that received inoculum and only these will be discussed. For this same reason plots receiving only fertilizer cannot be compared to inoculated plots or plots receiving both fertilizer and rhizobia.

The application of $147 \mathrm{~kg} / \mathrm{ha}$ of ammonium nitrate (34-0-0) or $50 \mathrm{~kg} / \mathrm{ha}$ of actual $\mathrm{N}$ did not have any effect on vegetative growth (Tables 1 and 2 Appendix). When the inoculated treatments were compared to the fertilizer and rhizobia treatments there were essentially no differences between the 
two for the other parameters investigated, these being nodulation and nitrogen fixation. Richards and Soper (1979) demonstrated that well-nodulated fababeans fix adequate amounts of nitrogen, and dry matter production is equivalent to plants receiving fertilizer nitrogen. These fertilizer treatments were not repeated in 1982 since no differences were noted the previous year. The discussion of the 1981 field experiment will center around the herbicide treatments, and in all cases the plants have been inoculated unless otherwise stated.

In 1982 metribuzin applications were much less phytotoxic to the crop than in 1981 (Figures $1 b$ and 2b). Metribuzin at $0.4 \mathrm{~kg} / \mathrm{ha}$ did not cause the severe suppression of growth that was observed in 1981 . The trend was for lower fresh and dry weights, compared to the inoculated control, but they were only significant for the last sampling date of August 17. Expressed as a percentage of the inoculated control, fresh and dry weights were 73.5 and $70.2 \%$ respectively.

As was observed in 1981, the trifluralin and metribuzin combinations were less phytotoxic than metribuzin applied alone, and fresh and dry weights did not differ significantly from the inoculated control (see also Tables 3 and 4 Appendix). For the last sampling date of August 17, 1982, the fresh and dry weights for the tank mix of $1.1 \mathrm{~kg} / \mathrm{ha}$ trifluraIin and $0.4 \mathrm{~kg} / \mathrm{ha}$ metribuzin was 86 and $82 \%$ of the inoculated 
control, respectively (Figures $1 b$ and $2 b$ ). The "safening effect" of trifluralin on metribuzin phytotoxicity was similar when either 0.82 or $1.1 \mathrm{~kg} /$ ha of trifluralin was included in the tank mix.

In order to explain the differences that were observed between the 1981 and 1982 growing seasons one must consider the factors that influence metribuzin activity. When metribuzin is applied as a preplant incorporated treatment, its activity is most strongly influenced by soil pH, organic matter content, and the degree of rainfall. Differences in all three of these factors at the two sites may help to explain the large degree of crop injury from metribuzin observed in 1981 .

The soil $\mathrm{pH}$ at the 1981 field site was determined to be 7.8, whereas, in 1982 the soil had a pH of 6.5. Weber et. al. (1969) investigated the adsorption of a number of s-triazines and found that the greatest degree of adsorption took place in the $\mathrm{pH}$ range that was closest to the pka of each herbicide. Metribuzin acts as a weak base, its pka being 1.1 as determined by weber (1980). Therefore at low pH it accepts $\mathrm{H}+$ ions and acts as a cation, thus it can be adsorbed by ion exchange forces. At a higher $\mathrm{pH}$, only physical adsorption takes place. Bailey et al. (1968) reported that the acidity at the surface of montmorillonite clay can be up to 3 to $4 \mathrm{pH}$ units lower than the $\mathrm{pH}$ of the soil solution. However, the $\mathrm{pH}$ of the field soils was much higher than the pka of metri- 
buzin. Even in 1981, when the soil pH was determined to be 6.5, the decrease in $\mathrm{pH}$ at the surface of the clay colloids that would be necessary for ionic bonding to occur is much higher than that estimated by Bailey et al. (1968). Thus, the differences in $\mathrm{pH}$ between the two field sites should not be a major factor influencing metribuzin availability.

The organic matter level of the soil was $4.8 \%$ at the 1981 field site and $5.7 \%$ at the 1982 site. This could also contribute to the higher levels of injury observed in 1981 . Sharom and Stephenson (1976) found organic matter to be the soil constituent most highly correlated with adsorption of metribuzin $(r=.996)$. In their studies with eight different Ontario soils, the authors observed a very low correlation between adsorption and clay content $(r=.45)$. The clay content was $7 \%$ higher at the 1982 field site. However, this difference is most likely not important in affecting adsorption. Savage (1976) also demonstrated that organic matter content, rather than clay content, was much more important in affecting adsorption. In his studies using sixteen different soils the author found that adsorption of ${ }^{14}$-metribuzin increased greatly as organic matter levels were increased. The adsorption only increased slightly when the clay content was increased from 0-408. Savage (1976) and Lafleur (1980) demonstrated that the mobility of metribuzin was negatively correlated with organic matter content, further suggesting the importance of organic matter in adsorption. Thus 
with the field soil having a slightly higher organic matter content in 1982, one would expect greater adsorption and less metribuzin to be available for plant uptake.

The different organic matter levels between the two field sites may help to account for the higher levels of injury observed in 1981. However, the difference was not great enough to explain the dramatic differences in injury between the two growing seasons. By far, the most important factor leading to the increased metribuzin activity in 1981 was the degree of rainfall the sites received, along with the timing of the rainfalls.

The field site in 1981 was very poorly drained and the site received a large amount of rain (Table 5). In May the site received a total of $60.2 \mathrm{~mm}$ of rainfall, and all of this occurred after metribuzin application and seeding. In May of 1982 the site received $23.9 \mathrm{~mm}$ of rain, with much of this taking place before herbicide application or seeding. Coble and Schrader (1973) demonstrated, in a greenhouse experiment, that soybean injury from metribuzin application increased as the level of simulated rainfall increased. With metribuzin having a water solubility of $1220 \mathrm{ppm}$, an increase in activity with an increase in moisture content would certainly be expected. The authors demonstrated that for a soil containing $3.3 \%$ organic matter a $1.12 \mathrm{~kg} / \mathrm{ha}$ rate of metribuzin applied as a pre-emergent treatment caused $23 \%$ injury when $1.25 \mathrm{~cm}$ of rain was applied every three days, starting 
Table 5. Precipitation for the 1981 and 1982 growing seasons at field sites.

\begin{tabular}{lcccc}
\hline & \multicolumn{2}{c}{1981} & \multicolumn{2}{c}{1982} \\
\cline { 2 - 5 } Month & $\begin{array}{l}\text { Total No. } \\
\text { of Rains }\end{array}$ & $\begin{array}{l}\text { Total } \\
\text { Precip. } \\
(\mathrm{mm})\end{array}$ & $\begin{array}{l}\text { Total No. } \\
\text { of Rains }\end{array}$ & $\begin{array}{l}\text { Total } \\
\text { Precip. } \\
(\mathrm{mm})\end{array}$ \\
\hline May & 3 & 60.2 & 9 & 23.9 \\
June & 9 & 83.6 & 14 & 64.1 \\
July & 7 & 49.3 & 13 & 83.6 \\
August & 2 & 93.7 & 11 & 30.5 \\
\hline TOTAL & 21 & 286.8 & 47 & 202.1 \\
\hline
\end{tabular}


immediately after the herbicide application. The level of injury was reduced to only $3 \%$ when the three-day watering regime was not initiated until 10 days after herbicide application. Thus the upper $10 \mathrm{~cm}$ of soil was much drier in 1982 , and consequently plant uptake of metribuzin was less than in 1981.

Coble and Schrader (1973) also observed that as the organic matter level increased from 1.1 to $3.3 \%$ the level of injury was decreased. However, the same levels of injury were evident at the 3.3 and $7.8 \%$ organic matter levels. Those results would suggest, that for the field sites used in these experiments, the organic matter differences $(4.8 \%$ in 1981 and $5.7 \%$ in 1982) would not be as important as the differences in rainfall in influencing the degree of injury observed.

Based on work conducted by Lafleur (1980) it is doubtful that even the large amount of rain in May of 1981 would leach the metribuzin out of the root zone. The author studied metribuzin movement in soil columns using 2 different soils, one having an organic matter content of $1.3 \%$ and the other $2 \%$. After one $3 \mathrm{~cm}$ unit of rain, the soil with $1.3 \%$ organic matter had $22 \pm 6 \%$ of the applied metribuzin in the $20-30 \mathrm{~cm}$ depth of the column. The soil with $2 \%$ organic matter had no detectable levels of metribuzin move to this depth. The field site in 1981 had $4.8 \%$ organic matter, therefore if the results of the work done with soil columns can be applied, 
then the rain most likely did not leach the metribuzin out of the root zone of the germinating fababeans. This is especially true since the site was poorly drained.

The trifluralin treated plants did not display any injury symptoms in either year. In 1981 the trend, although not significant, was for greater vegetative growth of the plants receiving trifluralin at $1.1 \mathrm{~kg} / \mathrm{ha}$ than the inoculated control (Figures 1 and 2). This result is rather surprising and is not related to weed control since all the plots were hand weeded.

The pattern developing in the field studies with respect to crop tolerance was consistent for both growing seasons. The trifluralin treated plants were not visibly injured and essentially were similar to the inoculated control. Metribuzin caused extensive damage in 1981 leading to reduced crop stands. Injury was also prevalent in 1982 but at higher rates of metribuzin. During both years the level of injury for the tank mix of trifluralin and metribuzin was less than when metribuzin was applied alone. 
Nodulation and Nitrogen Fixation

The same pattern that existed for the herbicidal effect on vegetative growth was evident for the assessment of nodulation that was made. In 1981, based on the dry weight of nodules on a per plant basis, it was determined that metribuzin at $0.42 \mathrm{~kg} / \mathrm{ha}$ was the most detrimental to nodulation (Figure 3a). The trend was for the plants treated with trifluralin and metribuzin at 1.1 and $0.42 \mathrm{~kg} / \mathrm{ha}$ respectively to have higher levels of nodulation than the plants treated with only metribuzin at $0.42 \mathrm{~kg} / \mathrm{ha}$. Compared to the inoculated control, the tank mix and metribuzin treatments were 45.5 and $82 \%$ lower respectively, at the July 24 sampling date. The trifluralin treatment did not cause any reduction in nodule dry weights (see also Table 5 Appendix).

In 1982 metribuzin had a greater detrimental effect on the rhizobium-plant symbiosis than on the crop. When the data for plant dry weights and nodule dry weights (Figure $2 b$ and Figure 3b) is examined, the differences are quickly apparent. For the July 19 sampling date, metribuzin at 0.4 $\mathrm{kg} / \mathrm{ha}$ caused a 38.18 reduction in the dry weight of nodules compared to the inoculated control. The same rate of metribuzin resulted in only a $22.1 \%$ reduction in plant dry weight.

The tank mix of trifluralin and metribuzin at 1.1 and $0.4 \mathrm{~kg} / \mathrm{ha}$ respectively, was slightly less phytotoxic when compared to metribuzin applied alone. Nodule dry weight reductions with the tank mix were only 328 on the July 19 
Figure 3. Influence of herbicide application on plant nodulation based on the dry weight of nodules per plant for the years (A) 1981 and (B) $1982 . \mathrm{RH}=$ Inoculated control; $\mathrm{T}+\mathrm{RH}=\mathrm{Trifluralin}$ and Inoculum; $T+M+R H=$ Trifluralin and Metribuzin and Inoculum; $M+R H=$ Metribuzin and Inoculum. 

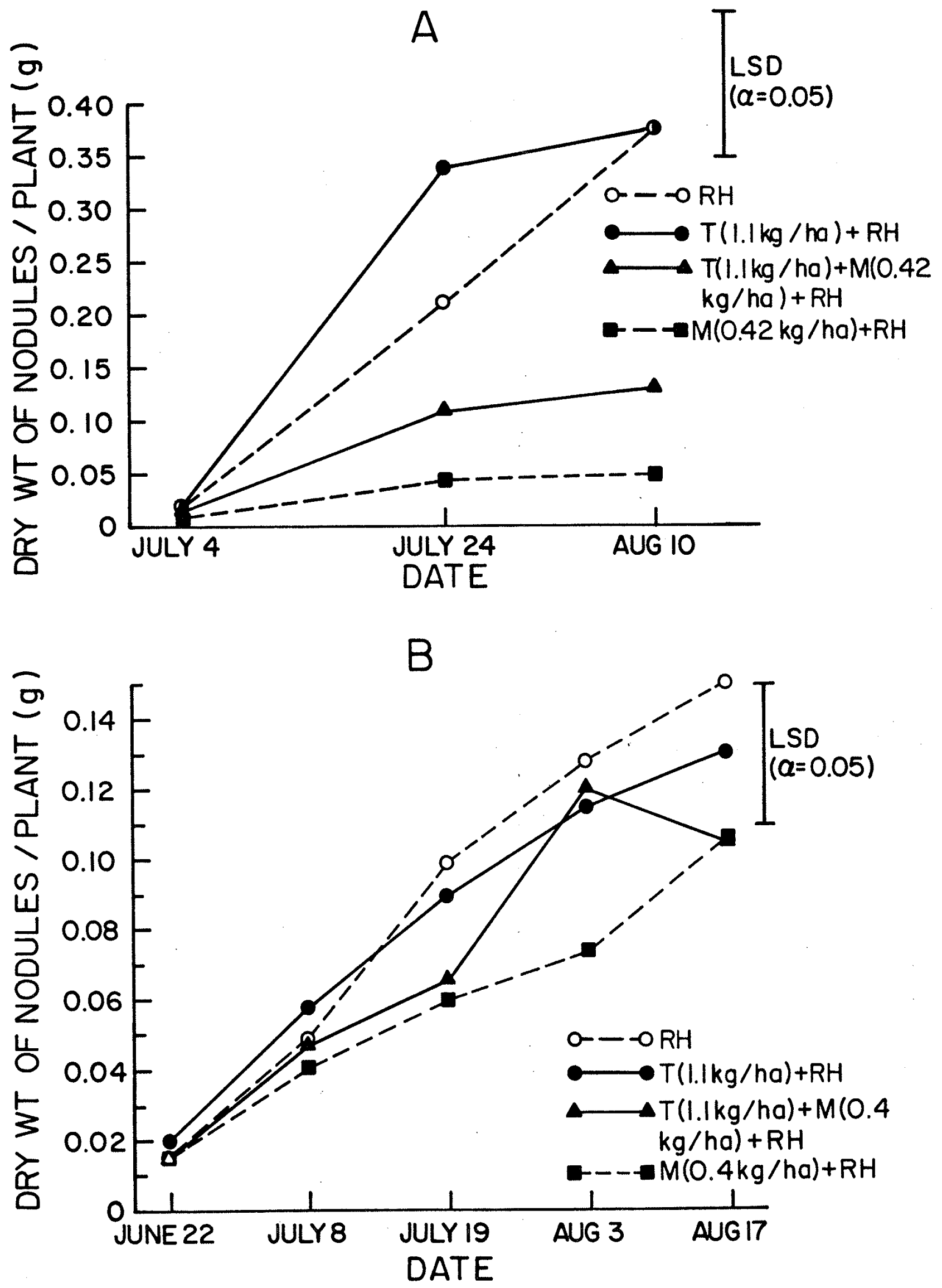
sampling date. The trifluralin treatment did not produce any significant reductions in the observed levels of nodulation (see also Table 6 Appendix).

The decreases in nodulation observed in these experiments seem to correspond to the levels of plant injury induced by metribuzin. In 1981 metribuzin was extremely phytotoxic, and based on plant dry weight measurements, the crop did not outgrow the severe injury and was always under stress. In 1982 reduced levels of nodulation were evident only where metribuzin caused observable plant injury. Thus during both years nodulation was affected only where the plants were injured and under stress. This would suggest metribuzin affects nodulation in an indirect way, through its action on the plant, and not by inhibiting growth of the bacteria directly.

The larger inhibition of nodulation in 1982 compared to dry weight reductions may be related to the supply of available photosynthate to the roots. It is also possible that metribuzin may interfere with one of the steps in the nodulation process. This again points to an indirect action of the herbicide.

Supporting evidence comes from a number of studies investigating the effect of herbicides on the symbiotic relationship between Rhizobium species and legumes (Carlyle and Thorpe 1947, Worsham and Giddens 1957, Peters and zbida 1979, Dunigan et al. 1972, Brock 1972, and Bethlenfalvay et 
al. 1979). The results of these studies indicate essentially two main points. Firstly, the herbicides studied were directly phytotoxic to the bacteria responsible for infection only at concentrations many times above normal field rates. Secondly, when decreases in nodulation or nitrogen fixation did occur it was only after the plant displayed injury symptoms as a result of the phytotoxic action of the herbicide on the plant.

In studies conducted by Carlyle and Thorpe (1947), 2,4$D[2,4-d i c h l o r o p h e n o x y a c e t i c$ acid] did not directly inhibit growth of the most sensitive strains of rhizobia investigated until extremely high concentrations were reached. Rhizobium trifolii and Rhizobium leguminosarum were not inhibited until a concentration equivalent to $224 \mathrm{~kg} / \mathrm{ha}$ was reached. On the other hand, plant growth and subsequently nodulation, was adversely affected by $0.23 \mathrm{~kg} / \mathrm{ha}$. The study by Brock (1972) can also serve to illustrate the indirect effect of herbicides on nodulation. The author demonstrated that trifluralin at $1.0 \mathrm{~kg} / \mathrm{ha}$ significantly reduced plant dry weights and the number of nodules per plant of a number of clover species. However, the author noted that nodules per plant and root dry weight were positively correlated. The number of nodules per unit root dry weight was not reduced by the 1.0 $\mathrm{kg} / \mathrm{ha}$ treatment. This would suggest that the herbicide was not having a direct effect on the Rhizobia, but that reductions in the number of nodules on a per plant basis were 
the result of an inhibition of root growth brought about with the application of trifluralin.

As expected, the nitrogenase activity levels observed, generally followed the pattern established with the nodule dry weights for the different treatments. In 1981 the value for the inoculated control at the second sampling date should, most likely, not be significantly different from the trifluralin treated plots (Figure 4 a). Nodule dry weights were not significantly different for the two treatments, nor were the acetylene reduction values for the earlier and later sampling dates. The lower level for the inoculated control was most likely due to a sampling error, or an error in the acetylene reduction procedure for that particular sample.

In 1981 the level of acetylene reduction for the plants treated with metribuzin at $0.42 \mathrm{~kg} / \mathrm{ha}$ was drastically lower than the inoculated control at all sampling dates. The tank mix treatment also produced acetylene reduction values that were much lower than the control, however the levels were higher than those for the metribuzin treatment. For example, at the July 4 sampling date the acetylene reduction values were $7.8,6.8,2.9$, and 0.3 umoles/plant/hour for the inoculated control, trifluralin at $1.1 \mathrm{~kg} / \mathrm{ha}$, the tank $\mathrm{mix}$, and metribuzin at $0.42 \mathrm{~kg} / \mathrm{ha}$ respectively (see also Table 7 Appendix).

In 1982 both the 0.4 and $0.6 \mathrm{~kg} / \mathrm{ha}$ treatments reduced nitrogenase activity, with the $0.6 \mathrm{~kg} / \mathrm{ha}$ treatment being 


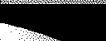

$$
73
$$

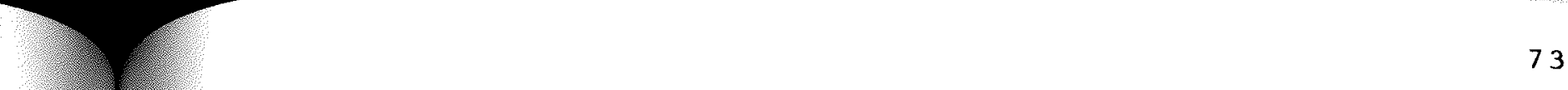

ㄴ. 3 
Figure 4. Influence of herbicide treatment on nitrogenase activity as measured by acetylene reduction for the years (A) 1981 and (B) 1982. RH = Inoculated control; $\mathrm{T}+\mathrm{RH}=$ Trifluralin and Inoculum; $\mathrm{T}+\mathrm{M}+\mathrm{RH}=$ Trifluralin and Metribuzin and Inoculum; $M+R H=$ Metribuzin and Inoculum. 

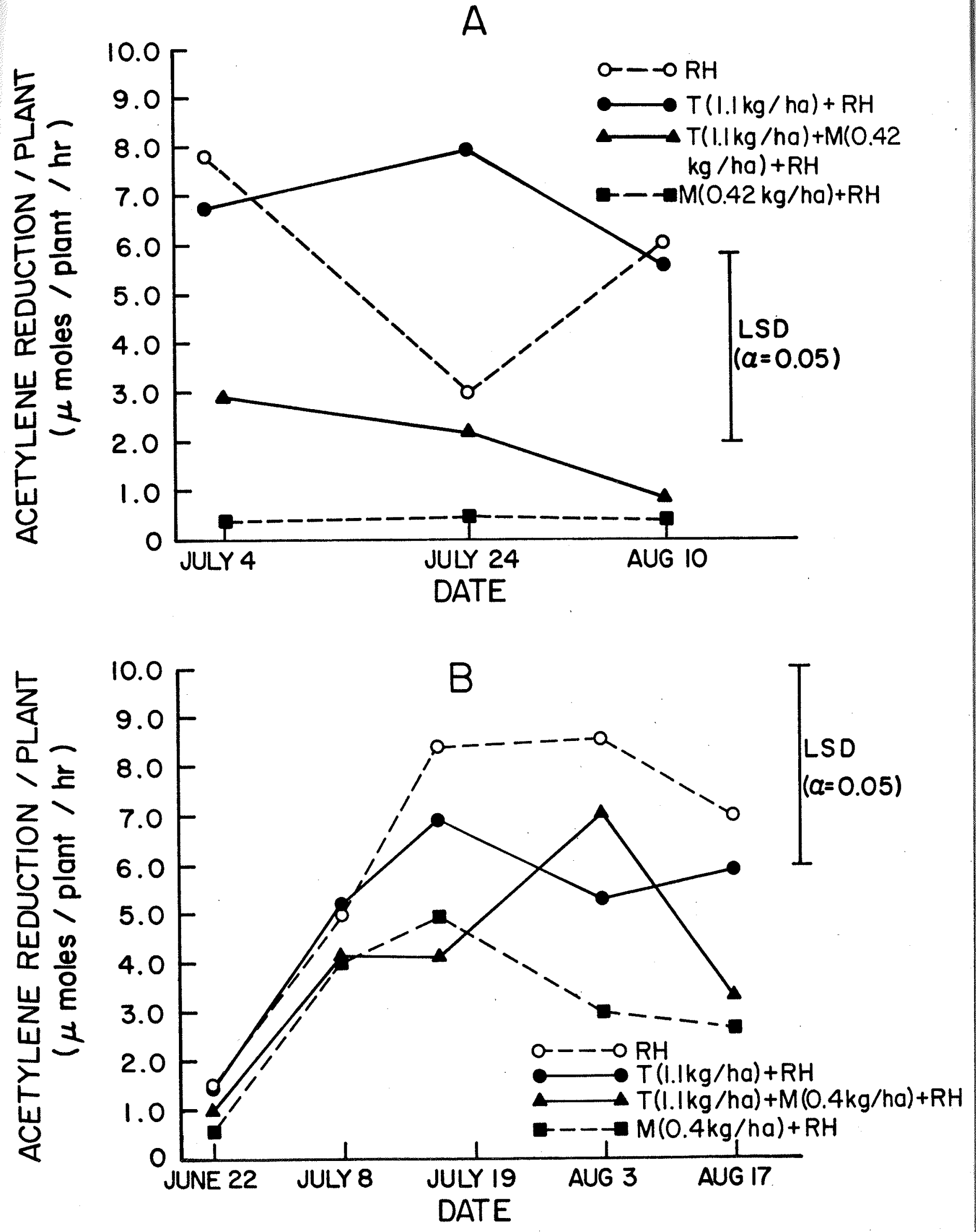
initially more phytotoxic (see Table 8 Appendix). The levels of acetylene reduction for the July 19 sampling date for the 0.4 and $0.6 \mathrm{~kg} / \mathrm{ha}$ treatments, respectively, were 58.3 and $25 \%$ of the inoculated control. These reductions, like those observed for nodulation were greater than the reductions in vegetative growth brought about by metribuzin application. The tank mix of trifluralin and metribuzin at 1.1 and 0.4 $\mathrm{kg} / \mathrm{ha}$, respectively, generally was less injurious than metribuzin applied alone (Figure 4b). The increse in acetylene reduction values of the tank mix compared to metribuzin applied alone was not significant, but the differences became greater later in the season. The levels of acetylene reduction for the tank $\mathrm{mix}$ and metribuzin at $0.4 \mathrm{~kg} / \mathrm{ha}$ on August 2 were 81 and $35 \%$ of the inoculated control respectively. The "safening effect" of trifluralin was similar regardless if the tank mix contained 0.82 or $1.1 \mathrm{~kg} / \mathrm{ha}$ of trifluralin (see Table 8 Appendix). The trifluralin treatments were not significantly different from the inoculated control. However, the trend was for the $1.1 \mathrm{~kg} / \mathrm{ha}$ rate of trifluralin to cause a greater reduction than the $0.82 \mathrm{~kg} / \mathrm{ha}$ rate.

One interesting observation can be made when the levels of nodulation and acetylene reduction are compared. Nodule dry weights increase for all the sampling dates during both growing seasons (Figures $3 a+b)$. The levels of acetylene reduction, however, peak at the July 24 and July 19 sampling dates in 1981 and 1982 respectively (Figures $4 a+b$ ). This 
would suggest a decrease in the efficiency of nitrogen fixation possibly due to increased competition for photosynthate. Ryle et al. (1979) found similar results with soybean and cowpea. The levels of nitrogen fixation decreased during the period of rapid pod fill. For the field experiments, the decreases in acetylene reduction values observed later in the season would correspond to the period of pod fill. However, as Richards and Soper (1979) determined, even with a decrease in efficiency, fababeans have a good proportion of the total $\mathrm{N}$ fixed occurring during pod fill.

Nodulation and nitrogen fixation, although beneficial, are very energy demanding processes and nodules represent a large photosynthetic sink. Bethlenfalvay et al. (1979) used bentazon [3-isopropyl-1 H-2, 1,3-benzothiadiazin-4-(3H)-one-2, $2,-$ dioxide] which, like metribuzin, inhibits photosynthesis to study the relationship between nitrogen-fixing capacity and apparent photosynthesis. Bean plants (Phaseolus vulgaris) were treated with $1.80 \mathrm{~kg} / \mathrm{ha}$ of bentazon. Apparent photosynthesis measured by the $\mathrm{CO}_{2}$ exchange rate reached a minimum 6 hours after treatment. The plant's nitrogen-fixing capability only recovered after the $\mathrm{CO}_{2}$ exchange rate became positive. This would suggest that the reductions in nitrogen fixation that were observed were due to a reduction in the supply of energy to the nodules.

The large energy requirements for nitrogen fixation have been recognized and a number of authors have attempted to 
establish the respiratory cost of fixation to a nodulated plant (Mahon 1977, Minchin and Pate 1973, and Ryle et al. $1979)$.

Ryle et al. (1979) established that soybean, cowpea, and white clover plants fixing their own nitrogen required 11-13\% more fixed carbon each day than did non-nodulated plants utilizing nitrate nitrogen. These results are similar to those observed by Minchin and Pate (1973) who found that 10.3 mg of carbohydrate were required for each mg of $N$ that the nodules fixed. Mahon (1977), under the conditions of his experiment, found that 17 grams of carbohydrate were consumed per gram of $\mathrm{N}$ fixed by nodules of pea (Pisum sativum).

Based on the large energy requirements and the reduction in fixation that occurs when an inhibitor of photosynthesis is used, the reductions observed in the present field studies are not surprising. Plants growing under stress would be expected to have poorer levels of nodulation and fixation. The plants injured as a result of metribuzin application were severely damaged and would be functioning at greatly reduced levels of $\mathrm{CO}_{2}$ fixation. In 1981 especially, and with the higher rates in 1982, the inhibitory effect was present throughout the growing season and these plants never fully recovered from the herbicide treatment. As a result, the levels of nodulation and nitrogen fixation were extremely reduced compared to the inoculated control. Plants receiving the tank mix application were not as severely damaged and 
consequently levels of nodulation and fixation were higher than for single applications of metribuzin.

\section{Effects on Protein and Nitrogen Levels}

During both 1981 and 1982 the percent protein levels were higher in the plants treated with high rates of metribuzin. In 1981 the protein content was always higher than the inoculated control for both the tank mix and metribuzin treatments (Figure 5a). Although it was not significant, the metribuzin treated plants fluctuated between 1 and 6\% higher protein than the inoculated control (see also Table 9 Appendix). In 1982 the levels of protein for both the 0.4 and $0.6 \mathrm{~kg} / \mathrm{ha}$ rate of metribuzin were again higher than the inoculated control. The differences were much less and the levels were only $1-2 \%$ higher for the metribuzin treatment (Figure 5b) (see also Table 10 Appendix).

Because of the stunting that occurred in both 1981 and 1982 from metribuzin application, the situation is reversed when total plant nitrogen is considered. The values for total $\mathrm{N}$ not only reflect $\frac{8}{8}$ nitrogen content, but also the size of the plant. Thus, because of the severe stunting observed in 1981, the plants treated with single applications of metribuzin had levels of total $\mathrm{N}$ that were much lower than the inoculated control (Figure 6a). Since less stunting occurred in the plots treated with the tank mix, the higher nitrogen levels were enough to enable these plants to have 

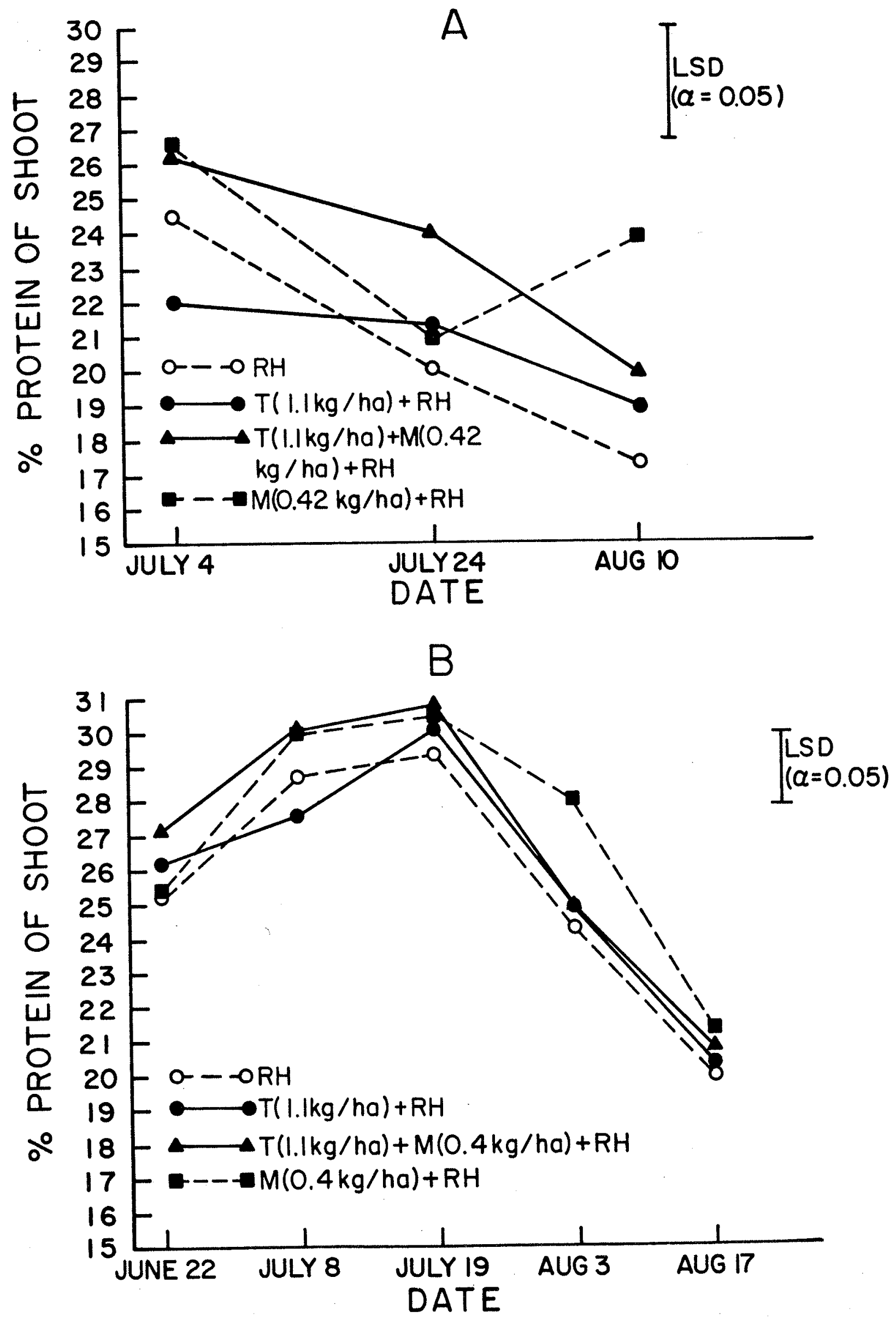

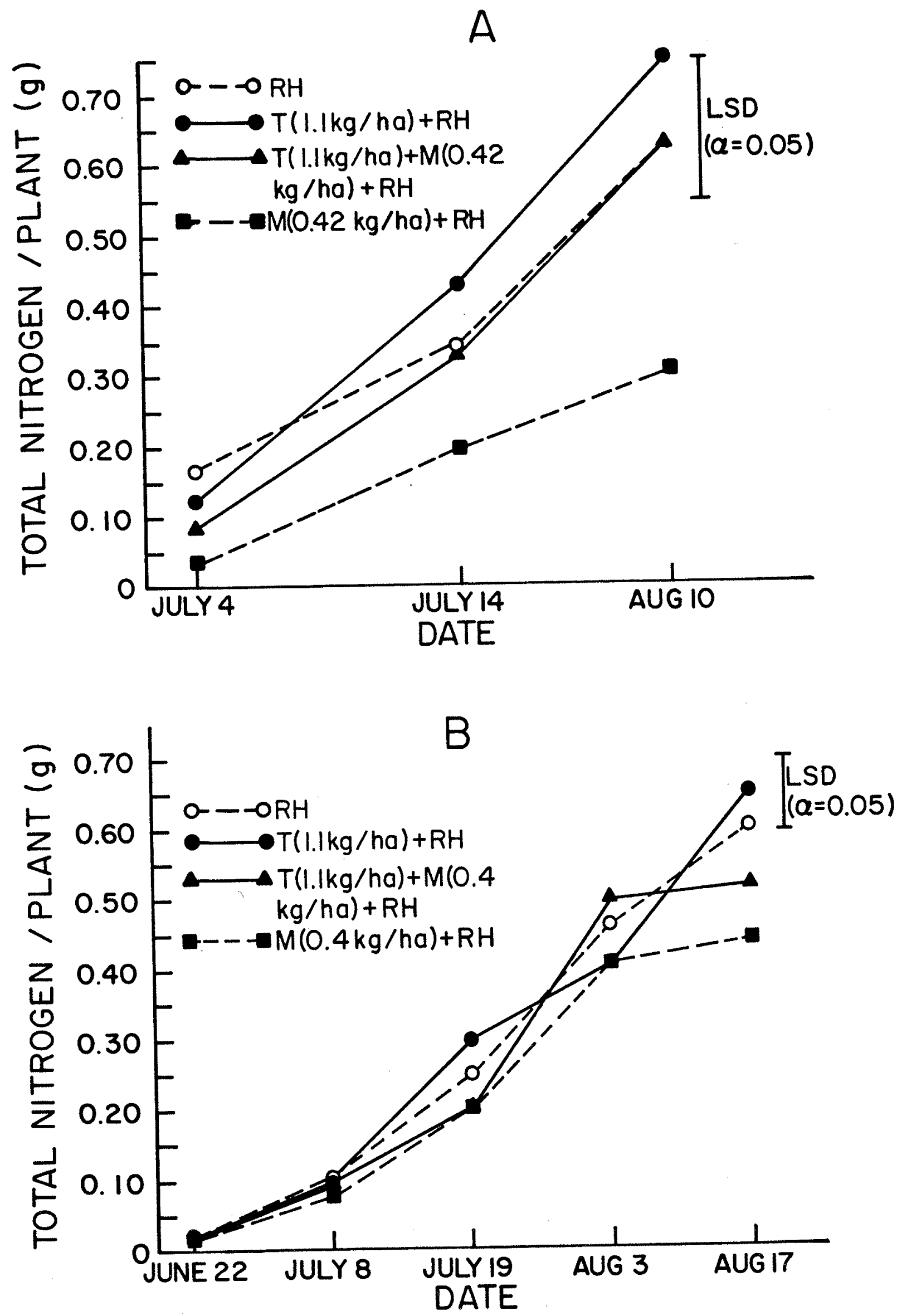
total $\mathrm{N}$ contents similar to the inoculated control (see also Table 11 Appendix). In 1982 the situation was similar, the marginally higher nitrogen levels did not offset the reduction in vegetative growth. This led to plants treated with metribuzin at 0.4 or $0.6 \mathrm{~kg} / \mathrm{ha}$ to have lower total $\mathrm{N}$ contents (Figure 6b) (see also Table 12 Appendix).

Increased nitrate reductase activity, along with increases in amino acid and protein synthesis as a result of sub-lethal applications of atrazine have been reported by numerous authors. Similar results have been observed with metribuzin. Fedtke (1972) treated potatoes with metribuzin at 0.3 and $3 \mathrm{ppm}$. At a concentration of $0.3 \mathrm{ppm}$ increases in soluble amino acid and protein levels were observed along with a reduction in the level of reducing sugars. The author also noted that increases in nitrate reductase activity was correlated with the lower levels of reducing sugars. The enhanced nitrate reductase activity was only observed in plants with low sugar levels. The author also was able to cause potato plants to develop similar levels of sugars, amino acids, and protein by growing the plants in low light intensity.

Fedtke (1979) continued his experiments using soybean plants. When soybean roots were treated with a concentration of $3.7 \mathrm{M}$ of metribuzin the concentration of soluble reducing sugars in the primary leaves dropped to a low but constant level. Increases in the concentration of nitrate and nitrate 
reductase activity along with soluble amino acids was observed.

These types of experiments are conducted using sublethal concentrations of herbicide and have in many cases led to increases in plant dry weights. The relevance of those types of studies to the particular field experiments performed here may not be great since concentrations were higher and the plants were under greater stress. However, if Fedtke's findings of low levels of reducing sugars being negatively correlated with nitrate reductase activity are correct, then that may be a basis for explanation of the increased protein levels observed with metribuzin application, since these plants would be functioning at reduced levels of $\mathrm{CO}_{2}$ Eixation. Mohandos et al. (1978) have demonstrated increased glutamine and glutamate synthase activity with sub-lethal concentrations of atrazine in cereals which may also be possible with fababeans.

Total Available Nitrogen

In 1982, as mentioned previously, both an uninoculated control and a barley control were. included in the experiment in order to derive an estimate of the total available soil nitrogen. The plants in the uninoculated control could not be used in the estimate because of infection and nodulation by wild-type organisms in the soil. The levels for both nodule dry weights along with nitrogenase activity for the 
uninoculated control were lower, but not significantly different from the inoculated control.

Because of this, the estimate of total available soil nitrogen was based on only the barley control. Richards and Soper (1979) demonstrated that fababean and barley plants extracted similar amounts of nitrogen applied as fertilizer. In their experiments, barley shoots extracted 67.78 of the total $\mathrm{N}$ applied, while fababean shoots recovered $65.0 \%$ of the applied nitrogen. The similarity in uptake would seem to suggest that the use of a barley control to estimate available soil nitrogen to fababean plants is adequate if uninoculated fababeans or a non-nodulating isoline cannot be used. The estimate of available soil $\mathrm{N}$ at the 1982 field site, based on both barley seed and straw yield, is $132.6 \mathrm{~kg} / \mathrm{ha}$ (Table 6)

Using the same reasoning, an estimate of the total nitrogen fixed by fababeans can be obtained. On the last sampling date the average protein content of the inoculated control was $20.0 \%$. This was determined using the above ground portion of the plant which includes not only vegetative growth, but pods and seeds as well. The average dry weight of the $0.5 \mathrm{~m}$ samplings was 144 grams. Expressing this on a per hectare basis the total above ground yield was 9483 $\mathrm{kg}$. This represents a total of $303 \mathrm{~kg}$ of nitrogen. If the total available soil nitrogen was $132.6 \mathrm{~kg}$ then approximately 
TABLE 6. Estimation of total available soil nitrogen at the 1982 field site, based on a barley control.

\begin{tabular}{llllllll}
\hline & $\begin{array}{l}\text { Treat } \\
\text { ment }\end{array}$ & $\begin{array}{l}\text { Seed } \\
\text { Yield } \\
(\mathrm{kg} / \mathrm{ha})\end{array}$ & $\begin{array}{l}\text { Straw } \\
\text { Yield } \\
(\mathrm{kg} / \mathrm{ha})\end{array}$ & $\begin{array}{l}\text { \% Seed } \\
\text { Protein }\end{array}$ & $\begin{array}{c}\text { Seed } \\
\mathrm{N}\end{array}$ & $\begin{array}{l}\% \text { Straw } \\
\text { Protein }\end{array}$ & $\begin{array}{c}\text { Straw } \\
\mathrm{N}\end{array}$ \\
\hline 1 & 14 & 3239.4 & 3418.6 & 13.9 & 2.22 & 7.5 & 1.2 \\
2 & 14 & 3653.7 & 4238.4 & 14.8 & 2.37 & 7.5 & 1.2 \\
3 & 14 & 3332.2 & 3863.5 & 15.3 & 2.45 & 7.5 & 1.2 \\
4 & 14 & 3666.1 & 4555.7 & 16.2 & 2.59 & 7.5 & 1.2 \\
\hline
\end{tabular}

\begin{tabular}{ccc}
$\underset{N}{\text { Seed } \mathrm{kg} / \mathrm{ha}}$ & Straw kg/ha & Total kg/ha \\
\hline 71.9 & 41.0 & 112.9 \\
86.6 & 50.9 & 137.5 \\
81.6 & 46.4 & 128.0 \\
97.5 & 54.7 & 152.2 \\
\hline
\end{tabular}


$170 \mathrm{~kg}$ per hectare was fixed by the fababeans growing in the inoculated control.

\section{Final Grain Yield}

The pattern evident throughout the growing season of 1981 of a high degree of phytotoxicity due to metribuzin application and a reduction in phytotoxicity with the trifluralin and metribuzin tank mix was borne out in the final seed yield (Figure 7a). The yield for the inoculated control was $2435.0 \mathrm{~kg} / \mathrm{ha}$. In comparison, metribuzin applied at $0.42 \mathrm{~kg} / \mathrm{ha}$ resulted in a final seed yield of $841.7 \mathrm{~kg} / \mathrm{ha}$ which corresponds to a $65.4 \%$ yield reduction. The antagonistic effect of trifluralin on metribuzin activity resulted in higher seed yields compared to the application of metribuzin alone. The treatment of trifluralin and metribuzin at 1.1 and $0.42 \mathrm{~kg} / \mathrm{ha}$ respectively, produced a final grain yield of $1413.3 \mathrm{~kg} / \mathrm{ha}$ which corresponds to only a $42 \%$ yield reduction.

The reduced phytotoxicity of the tank mix compared to metribuzin applied alone, when seed yield is considered, are similar to the findings of Ladlie et al. (1977). They found that metribuzin at $0.28 \mathrm{~kg} / \mathrm{ha}$ reduced soybean yield to $70 \%$ of the control. When trifluralin was applied in combination with metribuzin the yield did not differ significantly from the control. The rates of trifluralin applied were from 0.28 to $0.84 \mathrm{~kg} / \mathrm{ha}$ and at least $0.56 \mathrm{~kg} / \mathrm{ha}$ of trifluralin was 
Figure 7. Final seed yield as affected by herbicide treatment for the years (A) 1981 and (B) 1982. $\mathrm{CON}=$ Uninoculated control; $\mathrm{RH}=$ Inoculated control; $\mathrm{TR}+\mathrm{RH}=$ Trifluralin and Inoculum; $\mathrm{TR}+\mathrm{M}+\mathrm{RH}=$ Trifluralin and Metribuzin and Inoculum; $\mathrm{M}+\mathrm{RH}=$ Metribuzin and Inoculum. In 1982 all treatments received inoculum. 
A

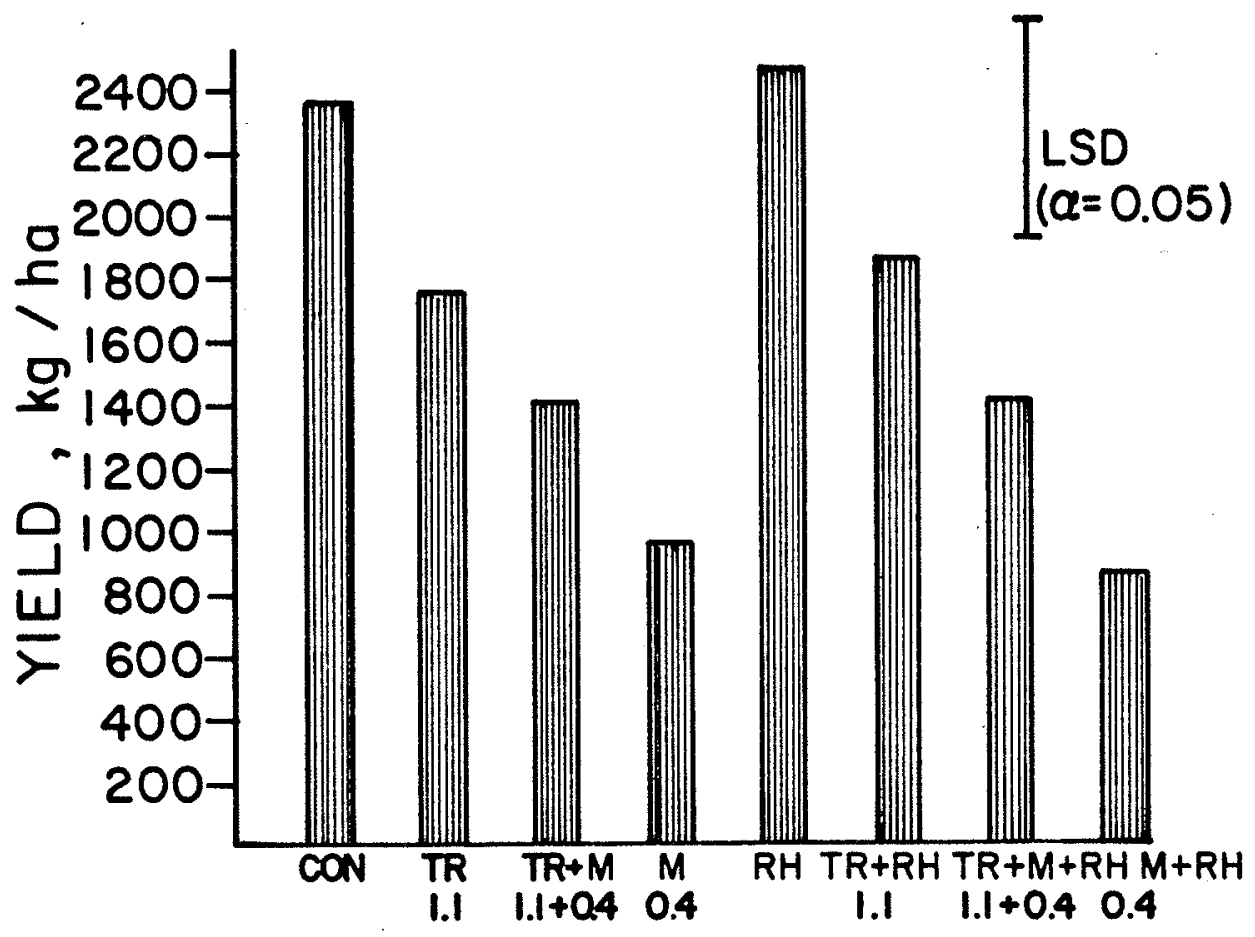

TREATMENT, $\mathrm{kg} / \mathrm{ha}$

$B$

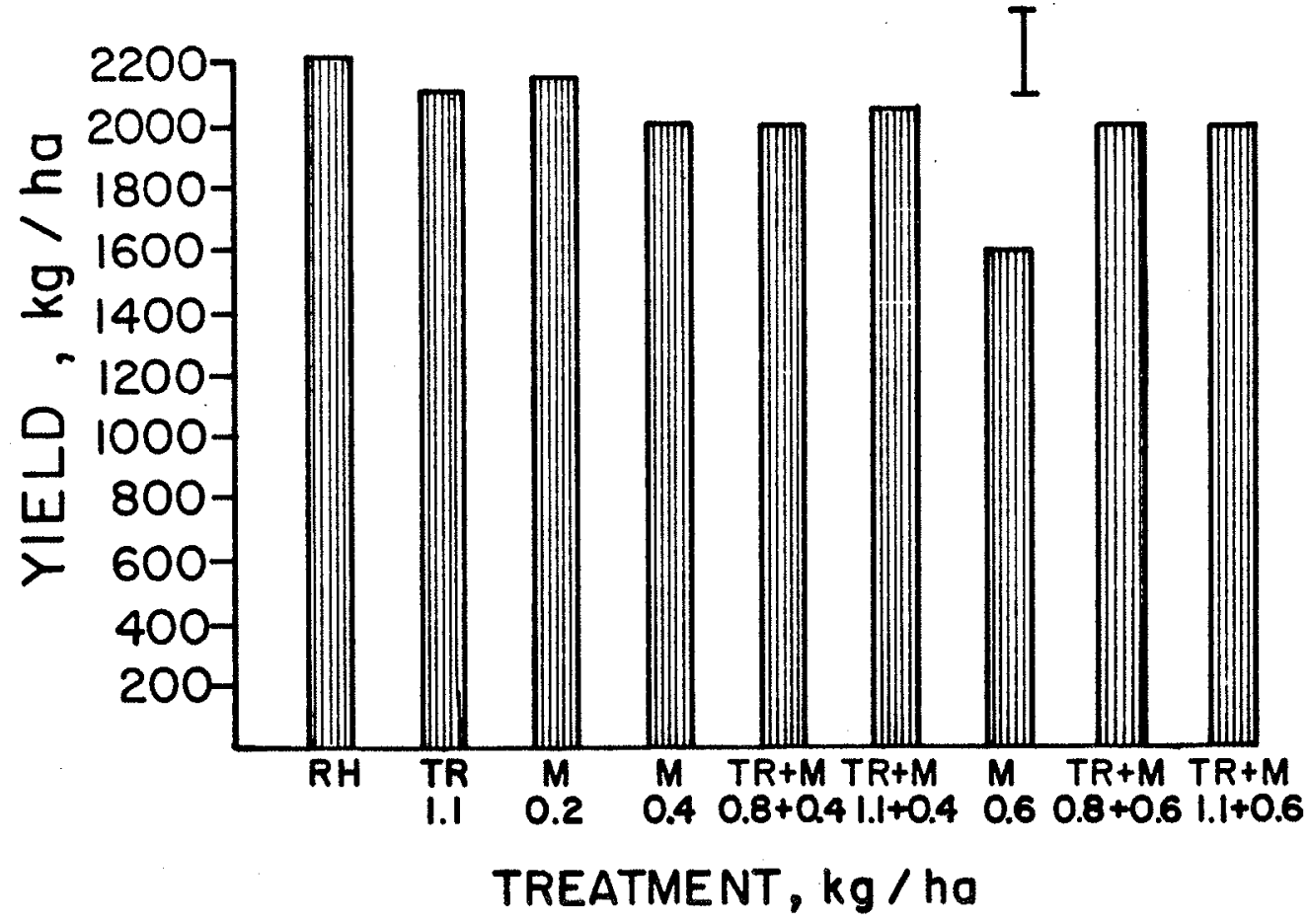


needed to ensure that no yield reduction occurred. Betts and Morrison (1979) also demonstrated in two out of three years of their study that metribuzin at $0.3 \mathrm{~kg} / \mathrm{ha}$ resulted in a significant yield reduction compared to a tank mix application of trifluralin and metribuzin.

The degree of injury from metribuzin application in 1982 was much less than in 1981 (Figure 7b). As explained earlier, differing soil, organic matter, and most importantly rainfall at the two sites accounted for the high degree of variability in metribuzin activity between the two growing seasons. The yield for the inoculated control was 2206.3 $\mathrm{kg} / \mathrm{ha}$. Metribuzin applied at $0.4 \mathrm{~kg} / \mathrm{ha}$ caused a $9 \%$ reduction to result in a final yield of $2008.4 \mathrm{~kg} / \mathrm{ha}$. This did not represent a significant reduction. Injury from this rate was minimal and therefore any benefit from a trifluralin and metribuzin tank mix was not observed. The tank mix of trifluraIin and metribuzin at 1.1 and $0.4 \mathrm{~kg} / \mathrm{ha}$, respectively, did not result in any significant yield improvement with a final seed yield of $2058.7 \mathrm{~kg} / \mathrm{ha}$.

Metribuzin at $0.6 \mathrm{~kg} / \mathrm{ha}$ caused significant reductions in vegetative growth, nodulation, and nitrogen fixation which were reflected in the final grain yield (Table 13 Appendix). This treatment resulted in a yield of $1594.1 \mathrm{~kg} / \mathrm{ha}$ which corresponds to a $28 \%$ reduction in yield compared to the inoculated control. The substantial injury and reduced yield at this rate allows the beneficial effect of the tank mix to be 
noted. Trifluralin plus metribuzin at 1.1 and $0.6 \mathrm{~kg} / \mathrm{ha}$ respectively resulted in a final seed yield of $1975.1 \mathrm{~kg} / \mathrm{ha}$. This corresponds to a $20 \%$ higher yield than when metribuzin was applied alone. A lower rate of trifluralin did not lessen the "safening effect" that was observed. Trifluralin applied in combination with metribuzin at 0.82 and $0.6 \mathrm{~kg} / \mathrm{ha}$ respectively, resulted in a final yield of $1986.0 \mathrm{~kg} / \mathrm{ha}$. This did not differ significantly from the yield for plots receiving the tank $\mathrm{mix}$ containing $1.1 \mathrm{~kg} / \mathrm{ha}$ (see Table 13 Appendix)

Hagood et al. (1980) investigated herbicide injury and the influence this has on yield potential of soybeans. The authors demonstrated the plasticity of the crop through the use of hand-thinned treatments. Significant yield reductions only occurred when the thinning rate reached $60 \%$. Metribuzin effects on the crop were evaluated on the basis of reduction in crop vigor, stand reduction, and yield. Crop vigor ratings were based on the severity of foliar chlorosis, necrosis, leaf malformation, and stunting. The authors discovered that less than $30 \%$ vigor reduction at the early growth stages were tolerated by the crop with no significant reductions in yield. When vigor reductions of $25 \%$ or greater persisted to later in the growing season, to the fifth to seventh trifoliate leaf stage, yield reductions occurred. Generally, if the plants recovered rapidly, a reduction in stand could be com- 
pensated for. Yield was reduced when injury persisted and when both vigor and stand were reduced.

These results can, in some respects, be applied to the data on yield and stand reduction for the 1981 and 1982 growing seasons. The injury from metribuzin application in 1981 was extremely severe. There was also a $29.3 \%$ reduction in plant stand (Table 14 Appendix). Although stand reduction was similar with the tank mix plant injury was not as severe, resulting in a higher final seed yield.

In 1982 the same rate of metribuzin was not as phytotoxic. Initial crop injury was outgrown and only a $12.8 \%$ reduction in crop stand, compared to the inoculated control, was observed (Table 14 Appendix). Thus yield was not significantly reduced. The $0.6 \mathrm{~kg} / \mathrm{ha}$ treatment of metribuzin caused a $31.2 \%$ reduction in plant stand and injury persisted for a longer period resulting in significant yield reductions. This would suggest that fababeans are also able to tolerate initial herbicide injury without significant yield reductions. Reductions in yield occur when the injury persists for a longer period, accompanied by reductions in plant stand.

\section{Growth Room Study}

A number of researchers have demonstrated through field experiments the reduction in crop injury that occurs when 
trifluralin and metribuzin are applied as a tank mix compared to single applications of metribuzin (Ladlie et al. 1977 , Moomaw and Martin 1978, Betts and Morrison 1979). In order to establish a possible basis for these results a growth room study investigating root growth after herbicide application was initiated.

Sampling was performed over a five week period. The initial sample was taken one week after emergence. This was followed by two samples at biweekly intervals so that the last sampling was done at five weeks after emergence.

At 1 week after emergence very dramatic differences were observed for the total root length in the $0-10 \mathrm{~cm}$ depth (Table 7). The roots in the control pots reached a total length of $281 \mathrm{~cm}$ in the $0-10 \mathrm{~cm}$ zone. This did not differ significantly from the plants treated with $0.42 \mathrm{~kg} / \mathrm{ha}$ of metribuzin. Root length in the $0-10 \mathrm{~cm}$ zone at the 0.42 $\mathrm{kg} / \mathrm{ha}$ of metribuzin was $273 \mathrm{~cm}$. At this time there was no visible injury from metribuzin application and shoot growth was unaffected. Trifluralin applied at $1.1 \mathrm{~kg} / \mathrm{ha}$ either alone or in combination with metribuzin caused extensive reductions in total root length within the treated zone. Total root lengths in the $0-10 \mathrm{~cm}$ zone were $141 \mathrm{~cm}$ and $122 \mathrm{~cm}$ for the trifluralin and tank mix treatments respectively. This corresponds to a $50 \%$ and $60 \%$ reduction in root length as a result of trifluralin application. Trifluralin at 0.82 $\mathrm{kg} / \mathrm{ha}$ did not result in as great an inhibition of lateral 
TABLE 7. Effect of trifluralin and metribuzin on root length, shoot dry weight, and root dry wefght 1 week after emergence ${ }^{a}$.

\begin{tabular}{|c|c|c|c|c|c|c|c|}
\hline Treatment $^{b}$ & $\begin{array}{l}\text { Root L10 } \\
(\mathrm{cm})\end{array}$ & $\begin{array}{l}\text { Root L20 } \\
(\mathrm{cm})\end{array}$ & $\begin{array}{l}\text { Root TOT } \\
(\mathrm{cm})\end{array}$ & $\begin{array}{c}\text { DW Root } 10 \\
(\mathrm{~g})\end{array}$ & $\begin{array}{c}\text { DW Root } 20 \\
(\mathrm{~g})\end{array}$ & $\begin{array}{c}\text { DW Root } 30 \\
(\mathrm{~g})\end{array}$ & $\begin{array}{c}\text { DW Shoot } \\
(\mathrm{g})\end{array}$ \\
\hline Control & 281 a & $90 \mathrm{ab}$ & 371 a & $0.17 \mathrm{a}$ & 0.04 & - & $0.35 \mathrm{a}$ \\
\hline $\begin{array}{l}\text { Trifluralin } \\
(0.82 \mathrm{~kg} / \mathrm{ha})\end{array}$ & $197 \mathrm{bc}$ & 75 b & 272 bc & $0.18 \mathrm{a}$ & $0.07 \mathrm{abc}$ & - & $0.31 \mathrm{a}$ \\
\hline $\begin{array}{l}\text { Trifluralin } \\
(1.1 \mathrm{~kg} / \mathrm{ha})\end{array}$ & $141 \mathrm{~cd}$ & $134 \mathrm{ab}$ & $275 \mathrm{bc}$ & $0.18 \mathrm{a}$ & $0.08 \mathrm{abc}$ & - & 0.32 a \\
\hline $\begin{array}{l}\mathrm{T} \text { at } 0.82 \\
\mathrm{~kg} / \mathrm{ha}+\mathrm{M} \text { at } \\
0.25 \mathrm{~kg} / \mathrm{ha}\end{array}$ & $205 \mathrm{~b}$ & $122 \mathrm{ab}$ & $326 \mathrm{abc}$ & $0.18 \mathrm{a}$ & $0.08 \mathrm{abc}$ & - & $0.26 \mathrm{a}$ \\
\hline $\begin{array}{l}\mathrm{T} \text { at } 0.82 \\
\mathrm{~kg} / \mathrm{ha}+\mathrm{M} \text { at } \\
0.42 \mathrm{~kg} / \mathrm{ha}\end{array}$ & $140 \mathrm{~cd}$ & $167 \mathrm{a}$ & $307 \mathrm{abc}$ & $0.16 \mathrm{a}$ & $0.05 \mathrm{bc}$ & -- & 0.28 a \\
\hline $\begin{array}{l}\mathrm{T} \text { at } 1.1 \\
\mathrm{~kg} / \mathrm{ha}+\mathrm{M} \text { at } \\
0.42 \mathrm{~kg} / \mathrm{ha}\end{array}$ & 122 & $134 \mathrm{ab}$ & $246 \quad c$ & $0.16 \mathrm{a}$ & $0.12 \mathrm{a}$ & - & $0.31 \mathrm{a}$ \\
\hline $\begin{array}{l}\text { Metribuzin } \\
(0.25 \mathrm{~kg} / \mathrm{ha})\end{array}$ & $255 \mathrm{ab}$ & $102 \mathrm{ab}$ & $357 \mathrm{ab}$ & $0.21 \mathrm{a}$ & $0.07 \mathrm{bc}$ & -- & $0.28 \mathrm{a}$ \\
\hline $\begin{array}{l}\text { Metribuzin } \\
(0.42 \mathrm{~kg} / \mathrm{ha})\end{array}$ & $273 a$ & $107 \mathrm{ab}$ & $380 \mathrm{a}$ & $0.20 \mathrm{a}$ & $0.90 \mathrm{ab}$ & - & $0.33 \mathrm{a}$ \\
\hline
\end{tabular}

ameans in columns followed by the same letter are not significantly different at the $5 \%$ level

according to Duncan's multiple range test.

$b_{\text {Root }} \mathrm{L} 10$ - Root length in the $0-10 \mathrm{~cm}$ zone

Root L20 - Root length in the $10-20 \mathrm{~cm}$ zone

Root L30 - Root length in the $20-30 \mathrm{~cm}$ zone

Root TOT - Total root length

DW - Dry weight 
root growth, compared to the $1.1 \mathrm{~kg} / \mathrm{ha}$ rate. The reduction in total root length in the $0-10 \mathrm{~cm}$ zone, compared to the untreated control was only $30 \%$ for the $0.82 \mathrm{~kg} / \mathrm{ha}$ rate of trifluralin. The differences between the two rates of trifluralin were less apparent when comparing the two tank mix treatments containing metribuzin at $0.42 \mathrm{~kg} / \mathrm{ha}$. The tank $\mathrm{mix}$ containing trifluralin at $0.82 \mathrm{~kg} / \mathrm{ha}$ caused a $50 \%$ reduction in total root length in the 0-10 cm depth. The tank mix containing $1.1 \mathrm{~kg} / \mathrm{ha}$ resulted in a $57 \%$ reduction. This did not represent a significantly higher level of inhibition of root growth.

At this sampling time there were no roots present in the 20-30 cm zone. The tank mix treatment containing $1.1 \mathrm{~kg} / \mathrm{ha}$ of trifluralin and $0.25 \mathrm{~kg} / \mathrm{ha}$ metribuzin is not included because of a misapplication of herbicide.

Although it was not significant, a trend worth noting developed in the $10-20 \mathrm{~cm}$ zone immediately below the treated layer. In this zone there seemed to be a compensatory growth of roots of plants receiving trifluralin treatments. The root length of the untreated control was $90 \mathrm{~cm}$ in the $10-20$ $\mathrm{cm}$ zone. However the total length of roots for the plants receiving the $1.1 \mathrm{~kg} /$ ha rate of trifluralin was $134 \mathrm{~cm}$ which corresponds to a $49 \%$ increase in total root length within the 
10-20 $\mathrm{cm}$ zone. This same increase in growth or compensation was evident for the tank mixes containing $0.82 \mathrm{~kg} / \mathrm{ha}$ or 1.1 $\mathrm{kg} / \mathrm{ha}$ of trifluralin and $0.42 \mathrm{~kg} / \mathrm{ha}$ of metribuzin (Table 7 ). Oliver and Frans (1968) using trifluralin at $1.1 \mathrm{~kg} / \mathrm{ha}$ were also able to demonstrate a compensatory production of lateral roots using soybean. The greatest increases usually occurred in the 1 inch segment immediately below the treated layer.

At 3 weeks after emergence the effect of trifluralin on inhibiting root growth was even more pronounced (Table 8). In the $0-10 \mathrm{~cm}$ depth the roots of the control were $1041 \mathrm{~cm}$ in total root length, whereas trifluralin at $1.1 \mathrm{~kg} / \mathrm{ha}$ resulted in a total length of only $230 \mathrm{~cm}$. This represents a $78 \%$ decrease in root length in the $0-10 \mathrm{~cm}$ zone due to lateral root inhibition by trifluralin. The $0.82 \mathrm{~kg} / \mathrm{ha}$ rate of trifluralin caused a $58 \%$ reduction in the $0-10 \mathrm{~cm}$ zone when compared to the untreated control. This smaller degree of inhibition with the lower rate of trifluralin was also evident when the two rates were compared in the tank mix with $0.42 \mathrm{~kg} / \mathrm{ha}$ of metribuzin.

Injury symptoms from metribuzin application were observed prior to this sampling date. Although not significantly, the dry weight of shoots was lower for the plants treated with $0.42 \mathrm{~kg} / \mathrm{ha}$ of metribuzin compared to the control. The roots appear to show greater sensitivity, with total root 
TABLE 8. Effect of trifluralin and metribuzin on root length, shoot dry weight, and root dry welght 3 week after emergence ${ }^{a}$.

\begin{tabular}{|c|c|c|c|c|c|c|c|c|c|c|}
\hline \multirow{3}{*}{$\begin{array}{l}\text { Treatment }^{b} \\
\text { Control } \\
\text { Trifluralin } \\
(0.82 \mathrm{~kg} / \mathrm{ha})\end{array}$} & \multicolumn{2}{|c|}{$\begin{array}{l}\text { Root L10 } \\
(\mathrm{cm})\end{array}$} & \multirow{2}{*}{$\begin{array}{c}\begin{array}{c}\text { Root L20 } \\
(\mathrm{cm})\end{array} \\
491 \mathrm{ab}\end{array}$} & \multirow{2}{*}{$\begin{array}{c}\begin{array}{c}\text { Root L30 } \\
(\mathrm{cm})\end{array} \\
287 \mathrm{a}\end{array}$} & \multicolumn{2}{|c|}{$\begin{array}{l}\text { Root TOT } \\
(\mathrm{cm})\end{array}$} & $\begin{array}{c}\text { DW Root } 10 \\
(\mathrm{~g})\end{array}$ & $\begin{array}{c}\text { DW Root } 20 \\
(\mathrm{~g})\end{array}$ & $\begin{array}{c}\text { DW Root } 30 \\
(\mathrm{~g})\end{array}$ & $\begin{array}{l}\text { DW Shoot } \\
(\mathrm{g})\end{array}$ \\
\hline & 1041 & & & & 1820 & a & $0.50 \mathrm{a}$ & $0.07 \quad b$ & $0.07 \mathrm{a}$ & $1.40 \mathrm{a}$ \\
\hline & 433 & bc & $662 \mathrm{a}$ & $368 \mathrm{a}$ & 1463 & $a b$ & $0.33 \mathrm{ab}$ & $0.17 \mathrm{ab}$ & $0.05 \mathrm{a}$ & $1.23 \mathrm{a}$ \\
\hline $\begin{array}{l}\text { Trifluralln } \\
(1.1 \mathrm{~kg} / \mathrm{ha})\end{array}$ & 230 & bc & $591 \mathrm{ab}$ & $400 a$ & 1220 & b & $0.25 \mathrm{~b}$ & $0.30 \mathrm{a}$ & $0.06 \mathrm{a}$ & $1.31 \mathrm{a}$ \\
\hline $\begin{array}{l}\mathrm{T} \text { at } 0.82 \\
\mathrm{~kg} / \mathrm{ha}+\mathrm{M} \text { at } \\
0.25 \mathrm{~kg} / \mathrm{ha}\end{array}$ & 425 & bc & $458 \mathrm{ab}$ & 354 a & 1237 & b & $0.39 \mathrm{ab}$ & $0.15 \mathrm{ab}$ & $0.09 \mathrm{a}$ & $1.46 \mathrm{a}$ \\
\hline $\begin{array}{l}\mathrm{T} \text { at } 0.82 \\
\mathrm{~kg} / \mathrm{ha}+\mathrm{M} \text { at } \\
0.42 \mathrm{~kg} / \mathrm{ha}\end{array}$ & 371 & $c d$ & $474 a b$ & $373 a$ & 1219 & b & $0.38 \mathrm{ab}$ & $0.10 \quad b$ & $0.12 \mathrm{a}$ & $1.19 \mathrm{a}$ \\
\hline $\begin{array}{l}\mathrm{T} \text { at } 1.1 \\
\mathrm{~kg} / \mathrm{ha}+\mathrm{M} \text { at } \\
0.42 \mathrm{~kg} / \mathrm{ha}\end{array}$ & 186 & d & 666 a & $317 \mathrm{a}$ & 1169 & $\mathrm{~b}$ & $0.33 \mathrm{ab}$ & $0.18 \mathrm{ab}$ & $0.11 \mathrm{a}$ & $1.46 \mathrm{a}$ \\
\hline $\begin{array}{l}\text { Metribuzin } \\
(0.25 \mathrm{~kg} / \mathrm{ha})\end{array}$ & 617 & b & $432 a b$ & 291 a & 1340 & $b$ & $0.38 \mathrm{ab}$ & $0.16 \mathrm{ab}$ & $0.12 \mathrm{a}$ & $1.17 \mathrm{a}$ \\
\hline $\begin{array}{l}\text { Metribuzin } \\
(0.42 \mathrm{~kg} / \mathrm{ha})\end{array}$ & 597 & $b$ & $307 \quad b$ & $301 \mathrm{a}$ & 1205 & b & $0.48 \mathrm{ab}$ & $0.10 \mathrm{~b}$ & $0.09 \mathrm{a}$ & $1.23 \mathrm{a}$ \\
\hline
\end{tabular}

Means in columns followed by the same letter are not significantly different at the $5 \%$ level according to Duncan's multiple range test.

$b_{\text {Root }} \mathrm{L10}$ - Root length in the $0-10 \mathrm{~cm}$ zone

Root L20 - Root length in the $10-20 \mathrm{~cm}$ zone

Root $\mathrm{L} 30$ - Root length in the $20-30 \mathrm{~cm}$ zone

Root TOT - Total root length

DW

- Dry weight 
length for plants receiving metribuzin at $0.42 \mathrm{~kg} / \mathrm{ha}$ being $597 \mathrm{~cm}$ which is $57 \%$ of the control.

At 3 weeks after emergence the compensatory process in the zone below the trifluralin treated layer was again evident. In the $10-20 \mathrm{~cm}$ zone the root length of the untreated control was $491 \mathrm{~cm}$, whereas the root lengths of the treatments containing the 0.82 and $1.1 \mathrm{~kg} / \mathrm{ha}$ rate of trifluralin were 662 and $591 \mathrm{~cm}$. This represents a 35 and $20 \%$ increase in root length in the $10-20 \mathrm{~cm}$ zone for both the low and higher rate of trifluralin, respectively.

When dry weights of roots are considered it becomes obvious that this is a less sensitive measure. Compared to the dry weight of the control the trifluralin treatment of $1.1 \mathrm{~kg} / \mathrm{ha}$ resulted in $50 \%$ lower root ary weights for the treated zone. This is much lower than the $78 \%$ reduction observed when root length is considered.

The lower sensitivity of root dry weight and the possible compensation of root growth as a result of trifluralin application may help to explain the results of Betts and Morrison (1979). In their studies the authors were unable to demonstrate lateral root inhibition of fababeans (Vicia faba) with both 1.0 and $2.0 \mathrm{~kg} / \mathrm{ha}$ applications of trifluralin.

Similar reductions in root length were evident for the sampling period 5 weeks after emergence (Table 9). Total 
root lengths in the $0-10 \mathrm{~cm}$ zone for the control, trifluralin at $1.1 \mathrm{~kg} / \mathrm{ha}$, and the tank $\mathrm{mix}$ of $1.1 \mathrm{~kg} / \mathrm{ha}$ of trifluralin and $0.42 \mathrm{~kg} / \mathrm{ha}$ of metribuzin were 2895,810 , and $669 \mathrm{~cm}$ respectively. The injury from metribuzin application at 0.42 $\mathrm{kg} / \mathrm{ha}$ was evident for both shoot and root growth. The total root length in the treated zone was $1571 \mathrm{~cm}$, which corresponds to $54 \%$ of the control. Shoot growth was also significantly reduced compared to the control. The lower sensitivity of root dry weights was also evident. Based on root length the reduction is $72 \%$, but when dry weight is considered the reduction is only $26 \%$.

O'Donovan and Prendeville (1976) demonstrated that trifluralin at a rate of $1.0 \mathrm{mg} / \mathrm{kg}$ reduced root fresh weight in the treated zone by approximately 50\% for pea (Pisum saticum) and soybean Glycine max). The reduction was due to lateral root inhibition.

As Parka and Soper (1977) point out, the inhibition of lateral or secondary root development by trifluralin and other dinitroanilines is a characteristic growth response to this family of herbicides. In these growth room studies only lateral root growth was affected. There was no visible inhibition of primary root growth. Bayer et al. (1967) found similar responses with cotton (Gossypium hirsutum L.). In the trifluralin treated zone only lateral roots of cotton 
TABLE 9. Effect of trifluralin and metribuzin on root length, shoot dry weight, and root dry weight 5 week after emergence ${ }^{a}$.

\begin{tabular}{|c|c|c|c|c|c|c|c|c|c|c|}
\hline Treatment $^{b}$ & $\begin{array}{l}\text { Root Ll0 } \\
(\mathrm{cm})\end{array}$ & $\begin{array}{l}\text { Root L20 } \\
(\mathrm{cm})\end{array}$ & $\begin{array}{l}\text { Root } \\
\text { (cn }\end{array}$ & L30 & $\begin{array}{l}\text { Root } \\
(\mathrm{cm})\end{array}$ & OT & $\begin{array}{c}\text { DW Root } 10 \\
(\mathrm{~g})\end{array}$ & $\begin{array}{c}\text { DW Root } 20 \\
(\mathrm{~g})\end{array}$ & $\begin{array}{c}\text { DW Root } 30 \\
(\mathrm{~g})\end{array}$ & $\begin{array}{l}\text { DW Shoot } \\
(\mathrm{g})\end{array}$ \\
\hline Control & 2895 a & $1984 \mathrm{a}$ & 217 & b & 5097 & & $1.37 \mathrm{ab}$ & $0.37 \mathrm{a}$ & 0.52 a & $6.06 \mathrm{a}$ \\
\hline $\begin{array}{l}\text { Trifluralin } \\
(0.82 \mathrm{~kg} / \mathrm{ha})\end{array}$ & 1013 bc & 1522 a & 212 & b & 2746 & c & $1.02 \mathrm{bc}$ & $0.44 \mathrm{a}$ & $0.49 \mathrm{a}$ & $5.28 \mathrm{ab}$ \\
\hline $\begin{array}{l}\text { Trifluralin } \\
(1.1 \mathrm{~kg} / \mathrm{ha})\end{array}$ & $810 \quad c$ & 1752 a & $369 a$ & $a$ & 2931 & c & $1.01 \mathrm{bc}$ & $0.61 \mathrm{a}$ & $0.71 \mathrm{a}$ & $5.02 \mathrm{ab}$ \\
\hline $\begin{array}{l}\mathrm{T} \text { at } 0.82 \\
\mathrm{~kg} / \mathrm{ha}+\mathrm{M} \text { at } \\
0.25 \mathrm{~kg} / \mathrm{ha}\end{array}$ & 1091 bc & 1829 a & 234 & b & 3154 & c & $1.28 \mathrm{ab}$ & $0.56 \mathrm{a}$ & $0.75 \mathrm{a}$ & $5.65 \mathrm{ab}$ \\
\hline $\begin{array}{l}\mathrm{T} \text { at } 0.82 \\
\mathrm{~kg} / \mathrm{ha}+\mathrm{M} \text { at } \\
0.42 \mathrm{~kg} / \mathrm{ha}\end{array}$ & 1085 bc & 1894 a & $218 a$ & a & 3196 & c & $1.12 \mathrm{abc}$ & $0.63 \mathrm{a}$ & $0.69 \mathrm{a}$ & $5.15 \mathrm{ab}$ \\
\hline $\begin{array}{l}\mathrm{T} \text { at } 1.1 \\
\mathrm{~kg} / \mathrm{ha}+\mathrm{M} \text { at } \\
0.42 \mathrm{~kg} / \mathrm{ha}\end{array}$ & $669 \quad \mathrm{c}$ & 1514 a & 200 & b & 2383 & c & 0.88 & $0.49 \mathrm{a}$ & $0.63 \mathrm{a}$ & $4.91 \mathrm{ab}$ \\
\hline $\begin{array}{l}\text { Metribuzin } \\
(0.25 \mathrm{~kg} / \mathrm{ha})\end{array}$ & $2464 a$ & $1714 \mathrm{a}$ & 183 & b & 4361 & & $1.47 \mathrm{a}$ & $0.52 \mathrm{a}$ & $0.53 \mathrm{a}$ & $5.39 \mathrm{ab}$ \\
\hline $\begin{array}{l}\text { Metribuzin } \\
(0.42 \mathrm{~kg} / \mathrm{ha})\end{array}$ & 1571 b & 1696 a & 184 & b & 3451 & $a b c$ & 0.86 & $0.56 \mathrm{a}$ & 0.77 a & $4.55 \mathrm{~b}$ \\
\hline
\end{tabular}

Means in columns followed by the same letter are not significantly different at the $5 \%$ level according to Duncan's multiple range test.

b

Root $\mathrm{L} 20$ - Root length in the $10-20 \mathrm{~cm}$ zone

Root $\mathrm{L} 30$ - Root length in the $20-30 \mathrm{~cm}$ zone

Root TOT - Total root length

DW

- Dry weight 
plants were inhibited. When cross-sections of the root were examined, only tissues of the pericycle and endodermis were abnormal. The number of cell layers comprising the pericycle were reduced. Also, the pericycle cells opposite the protoxylem were enlarged. This is the region where lateral roots are initiated. The author felt that lateral root growth was being inhibited because of abnormal cell division in the pericycle. The primary root tip appeared normal.

Both Ladlie et al. (1977), and O'Donovan and Prendeville (1976) correlated reduced uptake and translocation of triazines with trifluralin application. Ladiie et al. (1977) found that trifluralin at $1.68 \mathrm{~kg} / \mathrm{ha}$ reduced the level of ${ }^{14} \mathrm{C}$-metribuzin in soybean cotyledons, shoots, and roots by 48,28 , and $32 \%$ respectively compared to plants not treated with trifluralin. This seems to be directly related to the inhibition of root growth brought about by trifluralin. O'Donovan and Prendeville (1976), observed reductions in acropetal translocation of ${ }^{14} \mathrm{C}-\mathrm{simazine}$ in peas and ${ }^{14} \mathrm{C}$-atrazine in soybeans as a result of the trifluralin application and this was correlated with reduced injury. Based on these results, along with data from the growth room study, trifluralin inhibition of lateral root growth, with a subsequent reduction of metribuzin uptake might serve as an explanation of the results from the field studies.

The idea of trifluralin causing lateral root inhibition resulting in less absorption and translocation of metribuzin 
when the two are applied as a tank mix seems plausible based on the present growth room study, along with evidence on root growth and uptake studies provided by other authors. In the present study, reduction of lateral root growth was not significantly different for both rates of trifluralin. This may provide the explanation for both the 0.82 and $1.1 \mathrm{~kg} / \mathrm{ha}$ rates of trifluralin used in the tank mix providing similar levels of reduced phytotoxicity in the field experiment.

\section{Selecting for Increased Tolerance}

Numerous authors using both field and hydroponic studies have demonstrated that soybean varieties differ in terms of their tolerance to metribuzin (Hardcastle 1974, 1979, wax et al. 1976, Littlejohns 1977, Eastin 1980, Barrentine et al. 1976, Barrentine et al. 1982). This author is unaware of any studies investigating the possibility of fababeans showing the same differences in tolerance to metribuzin.

\section{Field experiment}

Because of the severity of injury in the 1981 field study, and the large reduction in stand that occurred with metribuzin application of $0.42 \mathrm{~kg} / \mathrm{ha}$, the plants that survived and produced seed were assumed to have a higher degree of tolerance towards metribuzin. The seed from those plants was used in a separate field study in 1982 and the seed is being increased in 1983 . 
In the 1982 field experiment this "selected seed" was increased in the presence of three rates of metribuzin. The rates were $0.2,0.4$, and $0.6 \mathrm{~kg} / \mathrm{ha}$. The method of incorporation and planting was the same as outlined for the 1982 field study in the Materials and Methods section. The seed harvested from the plants receiving the $0.6 \mathrm{~kg} /$ ha rate was the seed source for the selected seed in the following hydroponic experiment.

\section{Hydroponic Experiment}

The hydroponic study was conducted to further investigate the possibility of fababean varieties differing in terms of their tolerance to metribuzin. The commercial varieties investigated were Hertz Ereya, Outlook, and Aladin. Two University of Manitoba selections 80 FUMI and 80 FUM3 were included, in addition to the seed selected from the field study.

The experiment was terminated when the most susceptible plants in the treated tank were dead. Fresh and dry weights were determined for each variety in both the control and treated tanks (Table 10). The fresh and dry weights of Hertz freya was much lower than the other commercial varieties in the control tank. However, the fresh and dry weights of Hertz Ereya in the treated tank did not differ substantially from the other commercial varieties. This resulted in a 
TABLE 10. Differential varietal tolerance to metribuzin determined by shoot fresh and dry weight $(g)^{\text {a }}$.

\begin{tabular}{|c|c|c|c|c|c|c|}
\hline Variety & \multicolumn{2}{|c|}{ Control Tank } & \multicolumn{2}{|c|}{ Treated Tank } & \multicolumn{2}{|c|}{$\%$ of Contro1 } \\
\hline Hertz freya & $2.47 \quad \mathrm{~b}$ & 0.22 & $1.72 \mathrm{~b}$ & $0.17 \mathrm{bc}$ & $69.77 \mathrm{a}$ & $79.43 \mathrm{a}$ \\
\hline Outlook & $3.87 \mathrm{a}$ & $0.32 \mathrm{ab}$ & $1.88 \mathrm{~b}$ & $0.20 \mathrm{ab}$ & $48.63 \mathrm{~b}$ & $60.90 \mathrm{bc}$ \\
\hline Aladin & $4.22 \mathrm{a}$ & $0.38 \mathrm{a}$ & $1.95 \mathrm{~b}$ & $0.19 a b c$ & $46.15 \quad b$ & 50.26 \\
\hline Selected Seed & $3.88 \mathrm{a}$ & $0.32 \mathrm{ab}$ & $2.64 \mathrm{a}$ & $0.22 \mathrm{a}$ & $67.87 \mathrm{a}$ & $69.77 \mathrm{ab}$ \\
\hline 80FUM1 & $3.83 \mathrm{a}$ & $0.32 \mathrm{ab}$ & $1.71 \mathrm{~b}$ & 0.16 & $44.67 \quad b$ & 50.70 \\
\hline 80 FUM3 & $3.47 \mathrm{a}$ & $0.28 \mathrm{bc}$ & $2.10 \mathrm{~b}$ & $0.20 \mathrm{ab}$ & $60.40 \mathrm{ab}$ & $71.04 \mathrm{ab}$ \\
\hline
\end{tabular}

a Means in columns followed by the same letters are not significantly different at the $5 \%$ level according to Duncan's multiple range test. 
ranking of Hertz freya, on a percentage of the control basis, that may not be correct.

From the values of percent dry weight of the control for each treated variety significant differences can be observed (Table 10). Hertz freya had the highest value of 79.48 of the control. This is due to the poor growth of this variety in the control tank. Following this was 80FUM3, the selected seed, Outlook, 80FUMl, and Aladin at 71.0,69.8, 60.9, 50.7, and $50.3 \%$ of the control respectively. If Hertz freya is excluded then it would seem that there are real differences in tolerance, with 80 FUM 3 and the selected seed being the most tolerant. The variety Aladin and 80Fuml have significantly lower levels of tolerance.

Both the hydroponic studies along with field studies to investigate differences in tolerance would have to be repeated before positive differences in tolerance are identified. However, based on these preliminary experiments the possibility seems to exist for selecting more tolerant varieties. Since fababeans are heterogeneous, the possibility exists for selecting more tolerant plants within any one variety, as was done in this series of experiments. This may help to explain some of the variability encountered in the field experiments conducted in 1981 and 1982 .

The basis for differential tolerance to metribuzin is still unclear. However work conducted by a series of authors points to differential metabolism as the main mechanism 
whereby soybean varieties differ in tolerance to metribuzin (Smith and Wilkinson 1974, Hargroder and Rogers 1974, Mangoet 1979). This same explanation would seem to be the most plausible one for describing the differences observed in fababean varietal tolerance in the present experiment. 


\section{SUMMARY AND CONCLUSIONS}

Herbicide treatment is an integral part of fababean production. It is evident from the results presented in this study, that under certain conditions, herbicide application can be detrimental to both fababean growth and the plantrhizobium symbiosis that exists.

The range of fababean tolerance to metribuzin appears to be a narrow one. Metribuzin, applied as a preplant incorporated treatment in the spring, was extremely phytotoxic in 1981. Extremely low final grain yields with metribuzin treatment were attributed to substantial decreases in both vegetative growth and plant population. In 1982, the same rate of metribuzin resulted in some initial plant injury which was outgrown as the season progressed. Consequently, the dramatic yield reduction observed in 1981 was not evident. Higher than recommended rates of metribuzin were needed to cause significant reductions in vegetative growth and yield in 1982 .

The differences in the degree of phytotoxicity of metribuzin for the two growing seasons were largely dependent on differences in rainfall and organic matter at the two field sites. The activity of metribuzin is known to be negatively correlated with organic matter and positively correlated with soil moisture. The soil at the 1981 site had a slightly lower level of organic matter and a higher moisture content 
than the field soil at the 1982 site. This would contribute to the higher level of injury observed. By far the primary factor, in this case, influencing the differences in activity at the two sites was both the degree and timing of the rainfall that occurred at the two sites.

The degree of injury, in terms of either a reduction in vegetative growth or final seed yield, from metribuzin application was substantially reduced when metribuzin was applied in a tank mix with trifluralin. Although the level of injury with the tank mix was less than when metribuzin was applied alone, the degree of injury present was still not acceptable in 1981 .

The "safening effect" of the trifluralin and metribuzin tank mix can be related to the inhibition of lateral root development that occurs as a result of trifluralin application. Under growth room conditions extensive lateral root inhibition occured along the portion of the tap root located in the layer of soil treated with the tank mix. This inhibition is most likely the primary factor responsible for the "safening effect". The plants receiving only a metribuzin treatment have an initially larger total root length in the treated zone which would facilitate greater uptake of metribuzin leading to a higher degree of injury. The degree of lateral root inhibition was not significantly different for both the 0.82 and $1.1 \mathrm{~kg} /$ ha rates of trifluralin used.

Reductions in the level of nodulation based on nodule dry weight, and reductions in nitrogen fixation as estimated 
by acetylene reduction were observed with metribuzin application. Generally differences in nitrogen fixation between treatments, were reflected by the observed differences in nodule dry weights. The decreases observed appear to be due to indirect effects of metribuzin, and not a direct effect of the herbicide on the Rhizobium species tested. The decreases in nodulation and nitrogen fixation were only evident when crop injury was observed.

In 1982 reductions in nodulation and fixation, brought about by the $0.4 \mathrm{~kg} / \mathrm{ha}$ rate of metribuzin, were greater than the reductions in vegetative growth. This may suggest the symbiotic relationship has a greater sensitivity to the initial injury that developed than does the crop itself.

Differential varietal tolerance to metribuzin, and the ability to select for both more tolerant fababean varieties and plants within a particular variety seems possible. This would help to widen the range of tolerance fababean plants have to metribuzin and avoid reductions in nodulation or nitrogen fixation, which is one of the benefits to growing the crop. 


\section{RECOMMENDATIONS FOR FURTHER RESEARCH}

- Re-evaluate the wide range of rates recommended for metribuzin in the trifluralin and metribuzin tank mix. Preferably this should be done under irrigation so that rainfall, after herbicide application and planting, can be simulated if necessary.

- Conduct further experiments with the trifluralin and metribuzin tank $\mathrm{mix}$ and correlate root length with ${ }^{14} \mathrm{C}$ -metribuzin uptake.

- Relate reductions in available photosynthate induced by the application of a photosynthetic inhibitor like metribuzin to levels of nodulation or nitrogen fixation.

- Continue preliminary work on selecting for increased tolerance to metribuzin. In field studies use plants that have similar levels of tolerance to avoid the sort of variability in crop injury that can result from using plants that differ in terms of their tolerance to metribuzin. 


\section{LITERATURE CITED}

Anderson, W.P., A.B. Richards and S.W. Whitworth. 1968. Leaching of trifluralin, benefin, and nitralin in soil columns. Weed Sci. 16:165-168.

Ashton, F.M., and A.S. Crafts. 1981. Mode of action of herbicide. A Wiley-Interscience Publication; John Wiley and Sons, pp. 328-359.

Bailey, G.W., and J.L. White. 1970. Factors influencing the adsorption, desorption, and movement of pesticides in soil. Residue Rev. 32:29-92.

Bailey, G.W., J.L. White, and T. Rothberg. 1968. Adsorption of organic herbicides by montmorillonite: Role of $\mathrm{pH}$ and chemical character of adsorbate. Soil Sci. Soc. Amer. Proc. 32:222.

Barrentine, W.L., C.J. Edwards, and E.E. Hartwig. 1976. Screening soybeans for tolerance to metribuzin. Agronomy Journal $68: 351-353$.

Barrentine, W.L., E.E. Hartwig, C.J. Edwards, and T.C. Kilen. 1982. Tolerance of three soybean (Glycine max) cultivars to metribuzin. Weed Sci. 30:344-348.

Bayer, D.E., C.L. Foy, T.E. Mallory, and E.G. Cutter. 1967. Morphological and histological effects of trifluralin on root development. Am. J. Botony 54:945-952.

Bethlenfalvay, G.J., R.F. Norris, and D.A. Phillips. 1979 . Effect of bentazon, a Hill reaction inhibitor, on symbiotic nitrogen-fixing capability and apparent photosynthesis. Plant Physiol. 63:213-215.

Betts, M.F., and I.N. Morrison. 1979. Fall and spring applications of trifluralin and metribuzin in fababeans (Vicia Eaba). Weed Sci. 27:691-695.

Bode, L.E., C.L. Day, M.R. Gebhardt, and C.E. Goering. 1973. Prediction of trifluralin diffusion coefficients. Weed Sci. $21: 485-489$.

Bouchard, D.C., T.L. Lavy, and D.B. Marx. 1982. Fate of metribuzin, metolachlor, and fluometuron in soil. Weed Sci. 30:629-632.

Brock, J.L. 1972. Effects of the herbicides trifluralin and carbetamide on nodulation and growth of legume seedlings. weed Res. 12:150-154. 
Candlish, E., and K.W. Clark. 1975. Preliminary assessment of small fababeans grown in Manitoba. Can. J. Plant Science 55:89-93.

Carlyle, R.E., and J.D. Thorpe. 1947. Some effects of ammonium and sodium 2,4-dichlorophen-oxyacetate on legume and rhizobium bacteria. J. Am. Soc. Agronomy $39: 929-936$.

Coble, H.D., and J.W. Schrader. 1973. Soybean tolerance to metribuzin. Weed Sci. 21:308-309.

Dunigan, E.P., J.P. Frey, L.D. Allen, and A. McMahon. 1972. Herbicide effects on the nodulation of Glycine max (L.) Merrill. Agronomy Journal 64:806-808.

Eastin, E.F., J.W. Sij, and J.P. Craigmiles. 1980. Tolerance of soybean genotypes to metribuzin. Agronomy Journal 72:167-168.

Fedtke, C. 1972. Influence of photosynthesis-inhibiting herbicides on the regulation of crop plant metabolism. pest. Biochem. and Physiol. 2:312-323.

Fedtke, C. 1979. Physiological response of soybean (Glycine max) plants to metribuzin. Weed Sci. 27:192-195.

Frear, D.S. 1968. Herbicide metabolism in plants - 1 . Purification and properties of UDP-glucose:arylamine N-glucosyl-transferase from soybean. Phytochemistry $7: 381-390$.

Frear, D.S., C.R. Swanson, and R.E. Kadience. 1967. The biosynthesis of $\mathrm{N}-(3-\mathrm{Carboxy}-2$, 5-Dichlorophenyl) glucosylamine in plant tissue sections. Weeds $15: 101-104$.

Garcia, M.M., and D.C. Jordan. 1969. Action of 2,4-DB and dalapon on the symbiotic properties of Lotus corniculatus (Birdsfoot trefoil) - Plant and soil 30:317-334.

Giliberg, B.O. 1971. On the effects of some pesticides on rhizobium and isolation of pesticide-resistant mutants. Arch. Mikrobiol. 75:203-208.

Grover, R. 1974. Adsorption and desorption of trifluralin, triallate, and diallate by various adsorbents. Weed Sci. $22: 405-408$.

Hagood Jr., E.S., J.L. Williams Jr., and T.T. Bauman. 1980. Influence of herbicide injury on the yield potential of soybeans (Glycine max). Weed Sci. 28:40-45. 
Hardcastle, W.S. 1974. Differences in the tolerance of metribuzin by varieties of soybeans. Weed Res. $14: 181-184$.

Hardcastle, W.S. 1979. Soybean cultivar response to metribuzin in solution culture. Weed Sci. 27:278-279.

Hardy, R.W.F., R.D. Holsten, E.K. Jackson, and R.C. Burns. 1968. The acetylene-ethylene assay for $\mathrm{N}_{2}$ fixation: laboratory and field evaluation. Plant physiology 43 : 1185-1207.

Hargroder, T.G., and R.L. Rogers. 1974. Behavior and fate of metribuzin in soybean and hemp sesbania. Weed Sci. $22: 238-245$.

Hollist, R.L., and C.L. Foy. 1971. Trifluralin interactions with soil constituents. Weed Sci. 19:11-16.

Jordan, D.C., and M.M. Garcia. 1969. Interactions between $2,4-\mathrm{DB}$ and the root-nodule bacteria of Lotus corniculatus. Plant and Soil 30:360-372.

Kaszubiak, H. 1966. The effect of herbicides on rhizobium I susceptibility of rhizobium to herbicides. Acta Microbiol. Polonica 15:357-364.

Kust, C.A., and B.E. Struckmeyer. 1971. Effects of trifluralin on growth, nodulation, and anatomy of soybean. Weed Sci. 19:147-152.

Ladlie, J.S., W.F. Meggitt, and D. Penner. 1976a. Effect of $\mathrm{pH}$ on metribuzin activity in the soil. Weed Sci. 24:505-507.

Ladlie, J.S., W.F. Meggitt, and D. Penner. 1976b. Effect of soil pH on microbial degradation, adsorption, and mobility of metribuzin. Weed Sci. 24:477-481.

Ladlie, J.S., W.F. Meggitt, and D. Penner. 1976c. Role of $\mathrm{pH}$ on metribuzin dissipation in field soils. Weed Sci. 24:508-511.

Ladlie, J.S., W.F. Meggitt, and D. Penner. 1977. Effect of trifluralin and metribuxin combinations on soybean tolerance to metribuzin. Weed Sci. 25:88-93.

Ladlie, J.S., W.F. Meggitt, and D. Penner. 1977. Effect of atrazine on soybean tolerance to metribuzin. Weed Sci. 25: 115-121. 
Lafleur, K.S. 1979. Sorption of metribuzin by model soils and agronomic soils: Rates and equilibrium. Soil Sci. $127: 51-55$.

Littlejohns, D.A., W.R. Allen, and R.E. Pitblado. 1977. Effects of metribuzin on the performance of soybean cultivars. Can. J. Plant Sci. 57:551-554.

Mahon, J.D. 1977. Respiration and the energy requirement for nitrogen fixation in nodulated pea roots. Plant Physiol. 60:817-821.

Mangoet, B.L., F.E. Slife, and C.E. Rieck. 1979. Differential metabolism of metribuzin by two soybean cultivars. Weed Sci. 16:40-41.

Minchin, F.R., and J.S. Pate. 1973. The carbon balance of a legume and the functional economy of its root nodules. J. Exp. Botany 24:259-271.

Mohandas, S., W. Wallace, and D.J.D. Nicholas. 1978. Effects of atrazine on the assimilation of inorganic nitrogen in cereals. Phytochemistry 17:1021-1028.

Moomaw, R.S., and A.R. Martin. 1978. Interaction of metribuzin and trifluralin with soil type on soybean (Glycine max) growth. Weed Sci. 26:327-331.

Moyer, J.R. 1979. Soil organic matter, moisture, and temperature effect on wild oat control with trifluralin. Can. J. Plant Sci. 59:763-768.

Murray, D.S., J.E. Street, J.K. Soteres, and G.A. Buchanan. 1979. Growth inhibition of cotton and soybean roots and shoots by three dinitroanaline herbicides. Weed Sci. $27: 336-342$.

O'Donovan, J.T., and G.N. Prendeville. 1976. Interactions between soil-applied herbicides in the roots of some legume species. Weed Res. 16:331-336

Oliver, L.R., and R.E. Erans. 1968. Inhibition of cotton and soybean roots from incorporated trifluralin and persistance in soil. Weed Sci. 16:199-203.

Parka, S.J., and O.F. Soper. 1977. The physiology and mode of action of the dinitroaniline herbicides. Weed Sci. $25: 79-87$.

Peters, E.J., and M.B. Zbida. 1979. Effects of herbicides on nitrogen fixation of alfalfa (Medicugo sativa) and red clover (Trifolium pratense). Weed Sci. 27:18-21. 
Pritchard, M.K., and E.H. Stobbe. 1980. Persistance and phytotoxicity of dinitroaniline herbicides in Manitoba soils. Can. J. Plant Sci. 60:5-11.

Richards, J.E., and R.J. Soper. 1979. Effect of $N$ fertilizer on yield, protein content, and symbiotic $\mathrm{N}$ fixation in fababeans. Agronomy Journal 71:807-811.

Ryle, G.J., C.E. Powell, and A.J. Gordon. 1979. The respiratory cost of nitrogen fixation in soybean, cowpea, and white clover. J. Exp. Botony 30:135-144.

Savage, K.E. 1976. Adsorption and mobility of metribuzin in soil. Weed Sci. 24:525-528.

Sharom, M.S., and G.R. Stephanson. 1976. Behavior and fate of metribuzin in eight ontario soils. Weed Sci. $24: 153-160$.

Smith, A.E., and R.E. Wilkinson. 1974. Differential absorption, translocation, and metabolism of metribuzin by soybean cultivars. Physiol. Plant 32:253-257

Swanson, C.R., R.E. Kadunce, R.H. Hodgson, and D.S. Frear. 1966. Amiben metabolism in plants 1. Isolation and identification of an $\mathrm{N}-\mathrm{glucosyl}$ complex. Weeds $14: 319-323$.

Tennant, D. 1975. A test of a modified line intersect method of estimating root length. J. Ecology 63(3): 995-1001.

Thorton, J.S., and S.A. Schuman. 1972. A gas chromatographic method' for the determination of sencor and its deaminated diketo metabolite in soybeans. Chemagro Division of Baychem Corporation, Report No. 30387. Kansas City, MO.

Wax, L.M., E.W. Stoller, and R.L. Bernard. 1976. Differential response of soybean cultivars to metribuzin. Agronomy Journal 68:484-486.

Weber, J.B. 1980. Ionization of buthidazole, VEL 3510 , tebuthiuron, fluridane, metribuzone, and prometryn. Weed sci. 28:467-474.

Weber, J.R., S.B. Weed, and T.M. Ward. 1969. Adsorption of S-triazines by soil organic matter. Weed Sci. $17: 417-421$. 
Webster, G.R.B., C.F. Shaykewich, S. Kahai, and G.J. Reimer. 1978. Availability of the herbicide trifluralin for control of wild oats as influenced by soil characteristics in four Manitoba soils. Can. J. Soil Sci. $58: 397-404$.

Worsham, A.D., and J. Giddens. 1957. Some effects of 2,2-dichloropropionic acid on soil microorganisms. Weeds $5: 316-320$. 
APPENDIX 
Appendix

Table 1. Treatment effect on shoot fresh weight/plant $(g)^{a}$

1981

\begin{tabular}{|c|c|c|c|c|}
\hline Treatment ${ }^{b}$ & July 4 & July 24 & Aug 10 & Overall \\
\hline Control & $29.36 \mathrm{ab}$ & $109.63 \mathrm{a}$ & $109.27 \mathrm{abc}$ & $82.75 \mathrm{a}$ \\
\hline Nitrogen & $32.40 \mathrm{a}$ & $99.82 \mathrm{ab}$ & 105.17 abcd & $79.21 \mathrm{a}$ \\
\hline Trifluralin & $14.58 \mathrm{cde}$ & 75.08 bcde & $127.27 \mathrm{ab}$ & $72.41 \mathrm{abc}$ \\
\hline $\mathrm{T}+\mathrm{M}$ & $14.82 \mathrm{cde}$ & 64.70 cdefg & 89.52 abcde & $56.35 \mathrm{bcd}$ \\
\hline Metribuzin & $6.86 \mathrm{de}$ & 54.28 & 79.50 bcde & 46.88 \\
\hline $\mathrm{T}+\mathrm{N}$ & $13.61 \mathrm{cde}$ & 75.19 bcde & $149.92 \mathrm{a}$ & $76.58 \mathrm{ab}$ \\
\hline $\mathrm{T}+\mathrm{M}+\mathrm{N}$ & 10.67 & 38.73 & 67.47 cde & 38.96 \\
\hline $\mathrm{M}+\mathrm{N}$ & 5.21 & 30.31 & 50.51 & 28.68 \\
\hline Rhizobia & $30.03 \mathrm{ab}$ & 66.23 cdef & $111.69 \mathrm{abc}$ & $69.32 \mathrm{abc}$ \\
\hline $\mathrm{T}+\mathrm{RH}$ & $20.90 \mathrm{bc}$ & $80.21 \mathrm{bcd}$ & $120.16 \mathrm{abc}$ & $73.76 a b c$ \\
\hline $\mathrm{T}+\mathrm{M}+\mathrm{RH}$ & 13.88 & 49.64 & $99.42 \mathrm{abcde}$ & 54.31 \\
\hline $\mathrm{M}+\mathrm{RH}$ & 5.86 & 35.75 & 45.14 & 28.92 \\
\hline $\mathrm{N}+\mathrm{RH}$ & $28.55 \mathrm{ab}$ & $85.94 a b c$ & $142.98 \mathrm{a}$ & $85.83 \mathrm{a}$ \\
\hline $\mathrm{T}+\mathrm{N}+\mathrm{RH}$ & 16.86 & 86.06 abc & $118.09 \mathrm{abc}$ & $73.67 \mathrm{abc}$ \\
\hline $\mathrm{M}+\mathrm{N}+\mathrm{RH}$ & 7.12 & 38.41 & 44.07 & 29.87 \\
\hline $\mathrm{T}+\mathrm{M}+\mathrm{N}+\mathrm{RH}$ & 15.01 & 51.01 & $104.26 \mathrm{abcd}$ & 56.76 bcde \\
\hline
\end{tabular}

${ }^{a}$ Means in columns followed by the same letter are not significantly different at the 5\% level according to Duncan's multiple range test. $\mathrm{b}_{\text {Trifluralin applied at } 1.1 \mathrm{~kg} / \mathrm{ha}}$ Metribuzin applied at $0.42 \mathrm{~kg} / \mathrm{ha}$ 
Appendix

Table 2. Treatment effect on shoot dry weight/plant $(g)^{a}$ 1981

\begin{tabular}{|c|c|c|c|c|c|}
\hline Treatment $^{b}$ & July 4 & July & 24 & Aug. 10 & Overa11 \\
\hline Control & $4.03 \mathrm{ab}$ & 17.34 & & $22.03 \mathrm{abcd}$ & $14.47 \mathrm{a}$ \\
\hline Nitrogen & $4.37 \mathrm{a}$ & 15.85 & $\mathrm{ab}$ & $21.21 \mathrm{abcd}$ & $13.81 \mathrm{ab}$ \\
\hline Trifluralin & 2.63 bcde & 11.81 & $\mathrm{~cd}$ & $25.54 \mathrm{ab}$ & $13.33 \mathrm{abc}$ \\
\hline $\mathrm{T}+\mathrm{M}$ & 2.08 def & 10.16 & cdef & 18.85 bcde & $10.36 \mathrm{bcd}$ \\
\hline Metribuzin & 1.21 & 7.10 & efg & 14.66 cdef & 7.66 \\
\hline $\mathrm{T}+\mathrm{N}$ & 2.60 bcde & 11.64 & $\mathrm{~cd}$ & $27.99 \mathrm{ab}$ & $14.08 \mathrm{a}$ \\
\hline $\mathrm{T}+\mathrm{M}+\mathrm{N}$ & 1.58 def & 6.21 & $\mathrm{fg}$ & 12.67 def & 6.82 \\
\hline $\mathrm{M}+\mathrm{N}$ & 0.98 & 4.68 & $\mathrm{~g}$ & 10.36 & 5.40 \\
\hline Rhizobia & $4.34 a$ & 10.65 & cde & $22.54 \mathrm{abcd}$ & $12.51 \mathrm{abc}$ \\
\hline $\mathrm{T}+\mathrm{RH}$ & $3.68 \mathrm{abc}$ & 13.01 & $\mathrm{bc}$ & $24.86 \mathrm{ab}$ & $13.85 \mathrm{ab}$ \\
\hline $\mathrm{T}+\mathrm{M}+\mathrm{RH}$ & 2.03 & 8.83 & defg & $19.66 \mathrm{abcd}$ & 10.17 \\
\hline $\mathrm{M}+\mathrm{RH}$ & 1.01 & 5.80 & g & 8.26 & 5.03 \\
\hline $\mathrm{N}+\mathrm{RH}$ & $3.66 \mathrm{abc}$ & 13.26 & $b c$ & $29.45 \mathrm{a}$ & $15.46 \mathrm{a}$ \\
\hline $\mathrm{T}+\mathrm{N}+\mathrm{RH}$ & $3.09 \mathrm{abcd}$ & 13.10 & bc & $23.27 \mathrm{abc}$ & $13.15 \mathrm{abc}$ \\
\hline $\mathrm{M}+\mathrm{N}+\mathrm{RH}$ & 1.18 & 6.01 & $g$ & 8.46 & 5.22 \\
\hline $\mathrm{T}+\mathrm{M}+\mathrm{N}+\mathrm{RH}$ & 2.19 & 7.93 & defg & $21.04 \mathrm{abcd}$ & $10.39 \mathrm{bcd}$ \\
\hline
\end{tabular}

${ }^{a}$ Means in columns followed by the same letter are not significantly different at the 5\% level according to Duncan's multiple range test. $\mathrm{b}_{\text {Trifluralin applied at } 1.1 \mathrm{~kg} / \mathrm{ha}}$

Metribuzin applied at $0.42 \mathrm{~kg} / \mathrm{ha}$ 
Table 3. Treatment effect on fresh weight of shoot/plant $(g)^{a}$. 1982

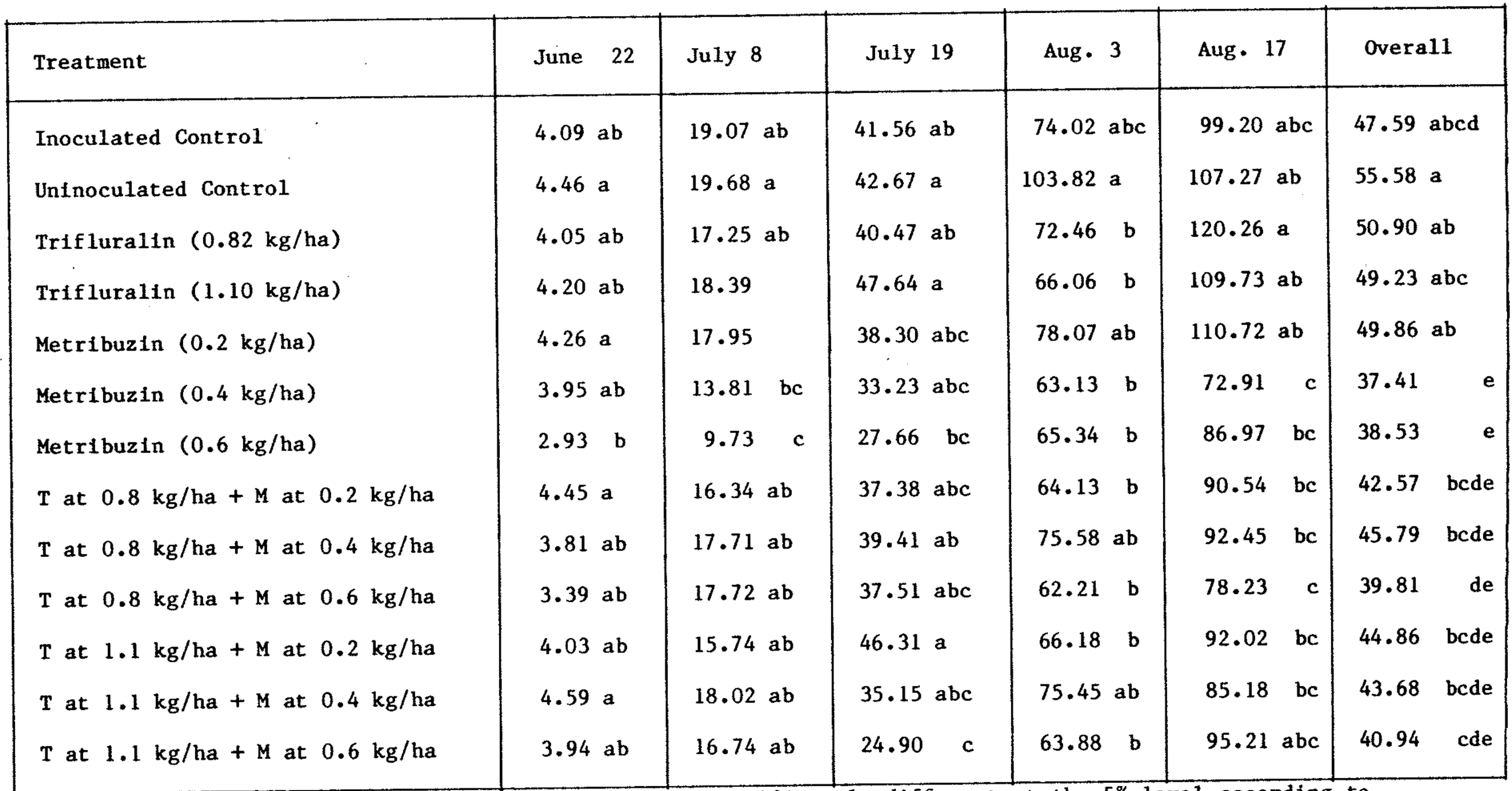

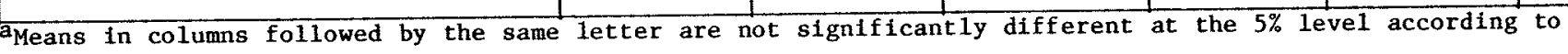
Duncan's multiple range test. 
Appendix

Table 4. Treatment effect on dry weight of shoot/plant $(\mathrm{g})^{\mathrm{a}}$. 1982

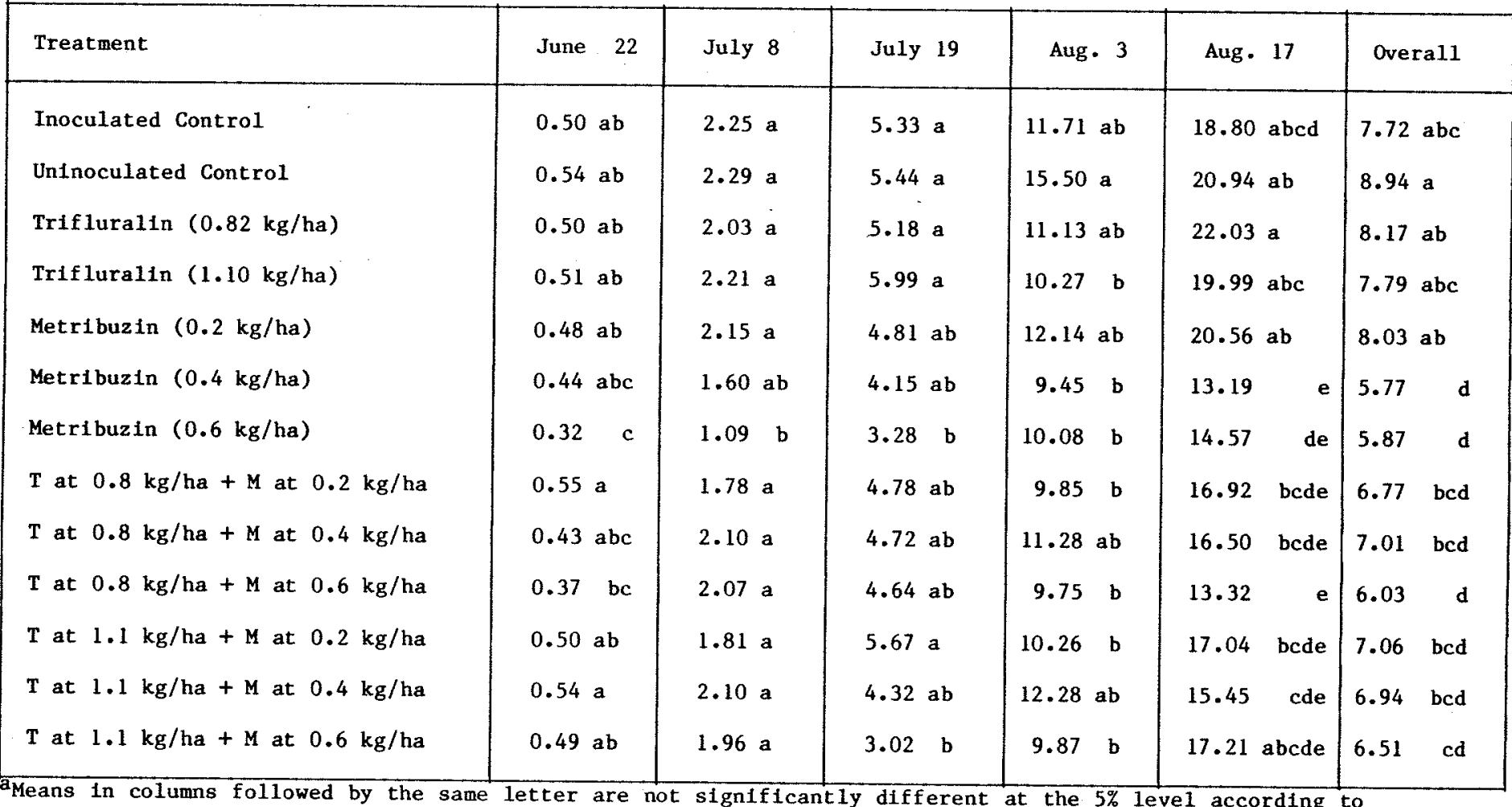

Duncan's multiple range test. 
Appendix

Table 5. Treatment effect on nodule dry weight/plant $(g)^{a}$. 1981

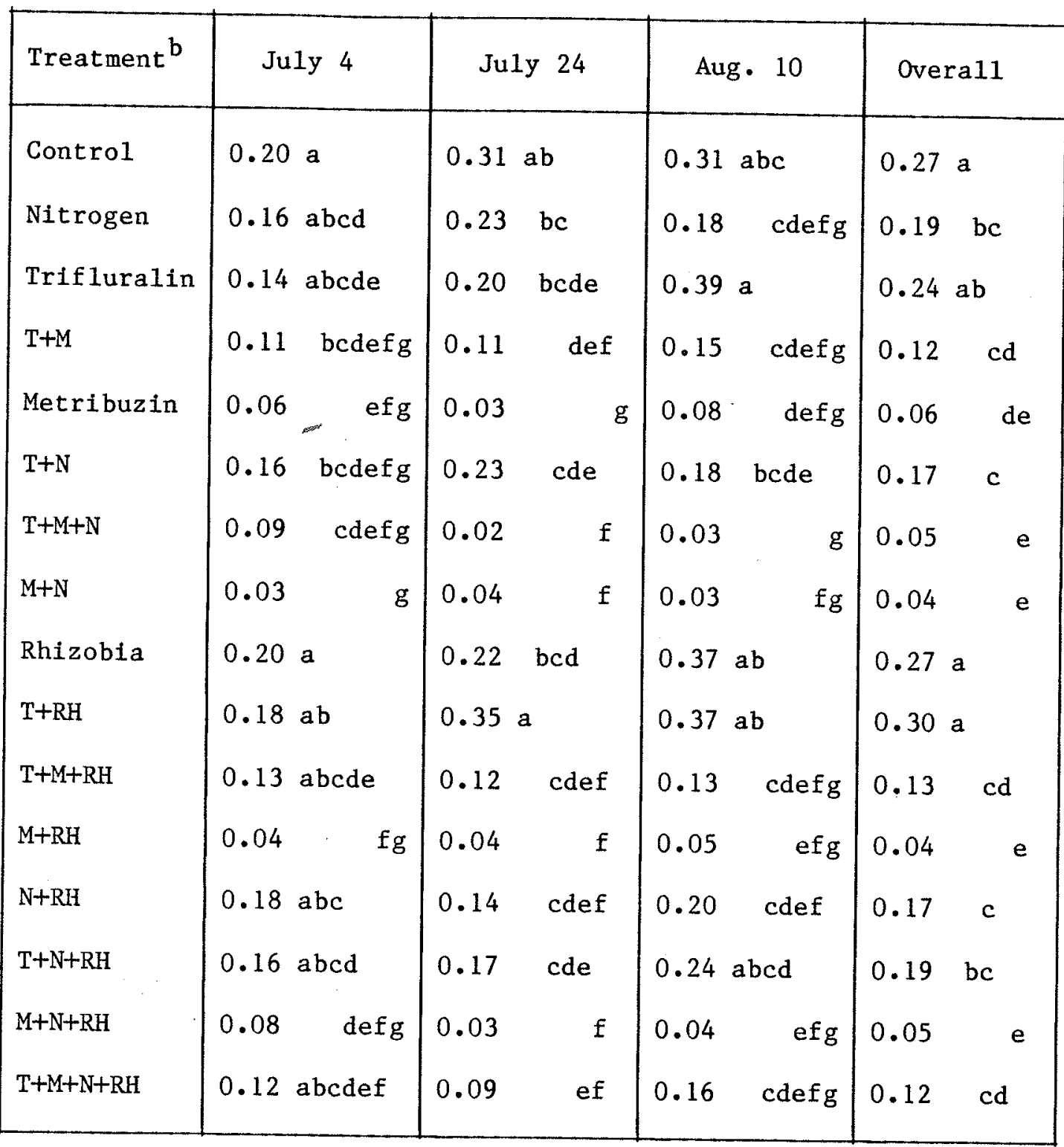

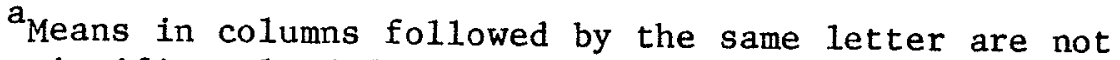
significantly different at the $5 \%$ level according to Duncan's multiple range test.

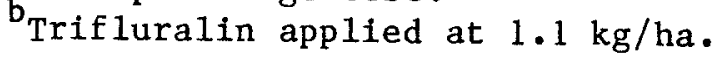
Metribuzin applied at $0.42 \mathrm{~kg} / \mathrm{ha}$. 
Table 6. Treatment effect on dry weight of nodules/plant $(\mathrm{g})^{\mathrm{a}}$. 1982

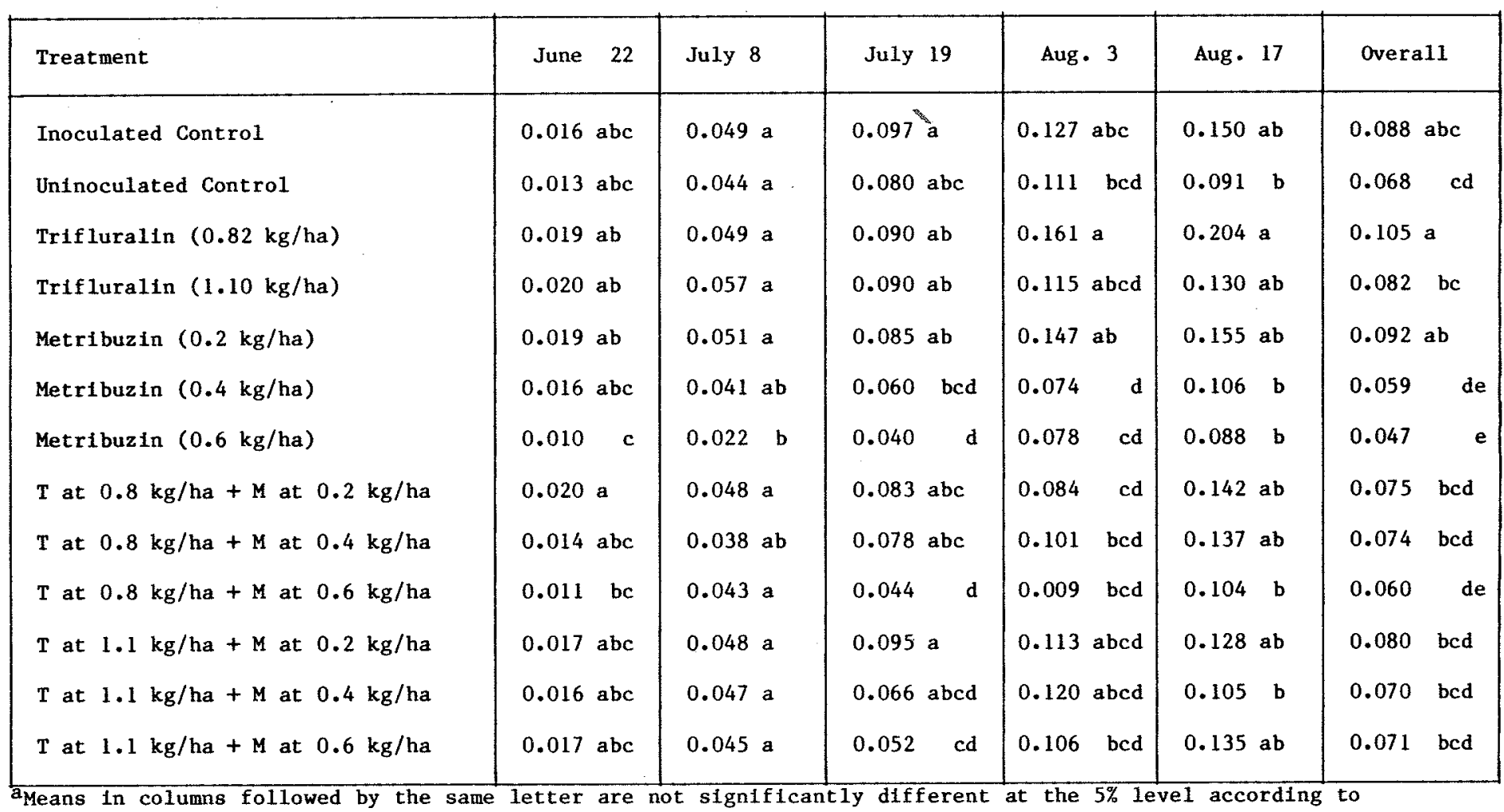


Appendix

Table 7. Treatment effect on nitrogenase activity (umoles/plant/hr) ${ }^{\mathrm{a}}$ 1981

\begin{tabular}{|c|c|c|c|c|}
\hline Treatment $^{b}$ & July 4 & July 24 & Aug. 10 & Overall \\
\hline Control & $5.4 \mathrm{abcd}$ & $6.6 \mathrm{ab}$ & $4.1 \mathrm{abc}$ & $5.4 \mathrm{ab}$ \\
\hline Nitrogen & $9.6 \mathrm{a}$ & $3.6 \mathrm{bc}$ & $2.5 \mathrm{abc}$ & $5.2 \mathrm{ab}$ \\
\hline Trifluralin & 3.3 bcde & $3.7 \mathrm{bc}$ & $6.5 \mathrm{a}$ & $4.5 \mathrm{bc}$ \\
\hline $\mathrm{T}+\mathrm{M}$ & $1.7 \mathrm{de}$ & 0.8 & $1.0 \quad b c$ & 1.2 \\
\hline Metribuzin & 0.1 & .0 .4 & 0.2 bc & 0.2 \\
\hline $\mathrm{T}+\mathrm{N}$ & 3.5 bcde & 2.1 & $3.4 \mathrm{abc}$ & $3.0 \mathrm{cde}$ \\
\hline$T+M+N$ & 0.4 & 0.5 & $0.3 \mathrm{bc}$ & 0.4 \\
\hline $\mathrm{M}+\mathrm{N}$ & 0.2 & 0.6 & $0.1 \quad c$ & 0.3 \\
\hline Rhizobia & $7.8 \mathrm{ab}$ & $3.3 \mathrm{bc}$ & $6.1 \mathrm{a}$ & $5.7 \mathrm{ab}$ \\
\hline $\mathrm{T}+\mathrm{RH}$ & $6.8 \mathrm{abc}$ & $7.9 \mathrm{a}$ & $5.7 \mathrm{a}$ & $6.8 a$ \\
\hline $\mathrm{T}+\mathrm{M}+\mathrm{RH}$ & 2.9 cde & 2.2 & $1.0 \mathrm{bc}$ & 2.1 \\
\hline $\mathrm{M}+\mathrm{RH}$ & 0.3 & 0.5 & $0.4 \mathrm{bc}$ & 0.4 \\
\hline $\mathrm{N}+\mathrm{RH}$ & $7.1 \mathrm{abc}$ & 2.2 & $4.3 \mathrm{ab}$ & $4.5 \mathrm{bc}$ \\
\hline $\mathrm{T}+\mathrm{N}+\mathrm{RH}$ & 4.4 bcde & $3.9 \mathrm{bc}$ & $2.8 \mathrm{abc}$ & $3.7 \mathrm{bcd}$ \\
\hline $\mathrm{M}+\mathrm{N}+\mathrm{RH}$ & 4.4 bcde & 0.4 & $0.1 \mathrm{bc}$ & 1.6 \\
\hline $\mathrm{T}+\mathrm{M}+\mathrm{N}+\mathrm{RH}$ & 3.6 bcde & 0.8 & $2.0 \mathrm{abc}$ & 2.4 \\
\hline
\end{tabular}

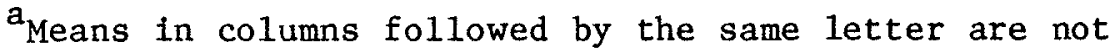
significantly different at the $5 \%$ level according to Duncan's multiple range test.

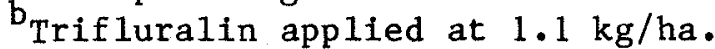
Metribuzin applied at $0.42 \mathrm{~kg} / \mathrm{ha}$. 
Table 8. Treatment effect on nitrogenase activity (umole/plant/hr) ${ }^{a}$ 1982

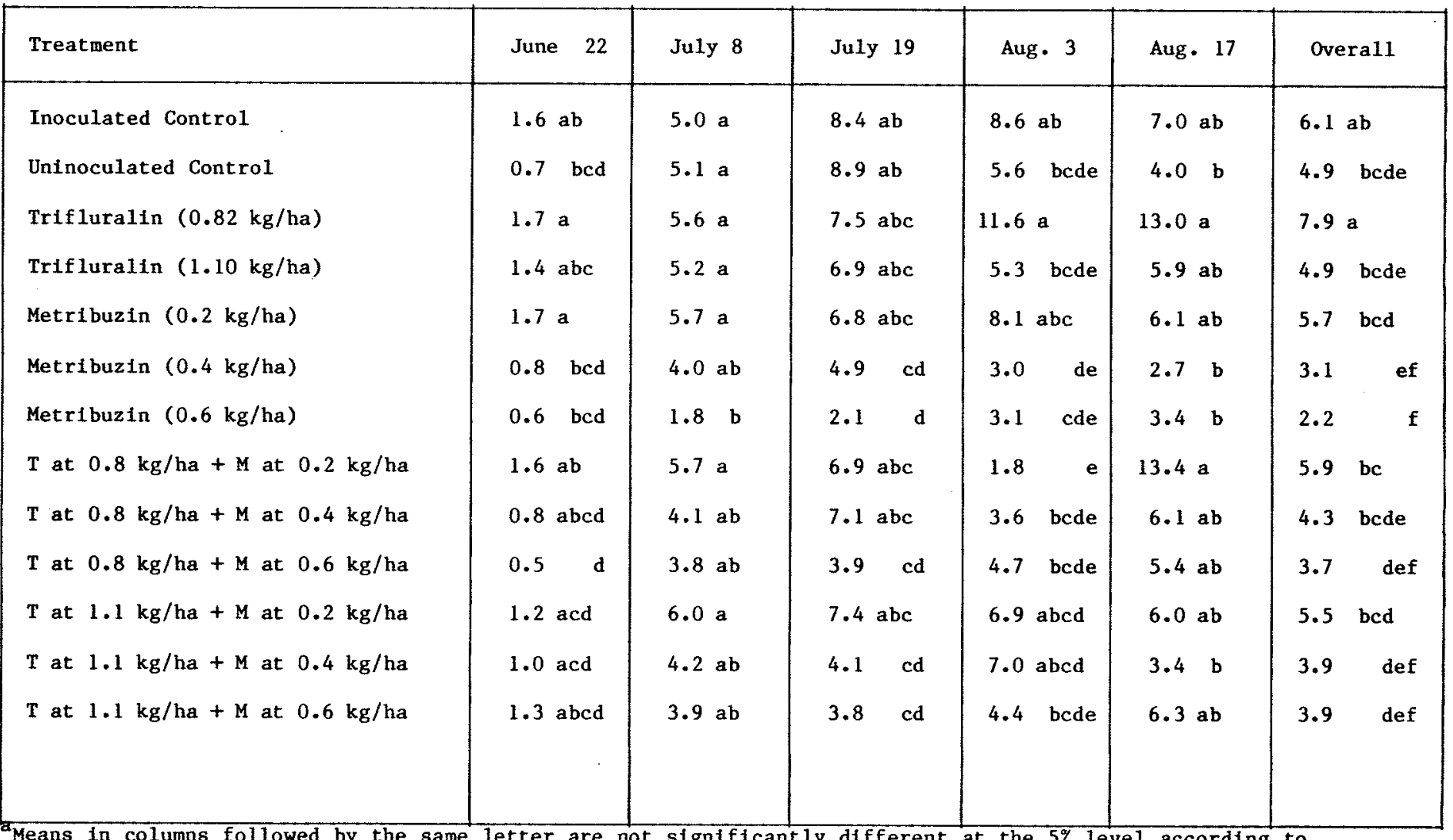

Duncan's multiple range test. 
Appendix

Table 9. Treatment effect on $\%$ protein ${ }^{a}$.

1981

\begin{tabular}{|c|c|c|c|c|c|}
\hline Treatment $^{b}$ & July 4 & Ju1y 24 & Aug. & 10 & Overall \\
\hline Control & $23.60 \mathrm{abc}$ & $21.47 \mathrm{abcd}$ & 17.67 & def & 20.91 cdef \\
\hline Nitrogen & $24.33 \mathrm{abc}$ & $19.63 \mathrm{~b}$ & 16.47 & $\mathrm{f}$ & 20.14 \\
\hline Trifluralin & $22.47 \quad b c$ & $20.97 \mathrm{abcd}$ & 18.13 & cdef & 20.52 def \\
\hline $\mathrm{T}+\mathrm{M}$ & $25.43 \mathrm{abc}$ & $23.07 \mathrm{abcd}$ & 18.73 & cde & 22.41 abcde \\
\hline Metribuzin & $25.53 \mathrm{abc}$ & $23.13 \mathrm{abcd}$ & 19.20 & cde & $22.62 \mathrm{abcd}$ \\
\hline $\mathrm{T}+\mathrm{N}$ & $23.23 \mathrm{bc}$ & $24.60 \mathrm{a}$ & 18.40 & cdef & 20.08 abcdef \\
\hline $\mathrm{T}+\mathrm{M}+\mathrm{N}$ & $25.80 \mathrm{abc}$ & $23.27 \mathrm{abcd}$ & 19.67 & $c d$ & $22.81 \mathrm{abc}$ \\
\hline$M+N$ & $28.60 \mathrm{a}$ & $23.77 \mathrm{abc}$ & 20.00 & bc & $24.12 \mathrm{a}$ \\
\hline Rhizobia & $24.50 \mathrm{abc}$ & $20.10 \mathrm{bcd}$ & 17.40 & ef & 20.67 \\
\hline $\mathrm{T}+\mathrm{RH}$ & $22.03 \quad \mathrm{c}$ & $21.37 \mathrm{abcd}$ & 19.00 & cde & 20.80 cdef \\
\hline $\mathrm{T}+\mathrm{M}+\mathrm{RH}$ & $26.33 \mathrm{abc}$ & $24.03 \mathrm{ab}$ & 19.87 & c & $23.41 \mathrm{ab}$ \\
\hline $\mathrm{M}+\mathrm{RH}$ & $26.57 \mathrm{abc}$ & $21.00 \mathrm{abcd}$ & 23.80 & $a$ & $23.79 a b$ \\
\hline $\mathrm{N}+\mathrm{RH}$ & $23.77 \mathrm{abc}$ & $19.90 \mathrm{~cd}$ & 17.20 & ef & 20.29 \\
\hline $\mathrm{T}+\mathrm{N}+\mathrm{RH}$ & $24.10 . a b c$ & $21.67 \mathrm{abcd}$ & 19.13 & cde & 21.63 bcdef \\
\hline $\mathrm{M}+\mathrm{N}+\mathrm{RH}$ & $27.30 \mathrm{ab}$ & $23.47 \mathrm{abcd}$ & 21.87 & $b$ & $24.21 \mathrm{a}$ \\
\hline $\mathrm{T}+\mathrm{M}+\mathrm{N}+\mathrm{RH}$ & $25.93 \mathrm{abc}$ & $22.73 \mathrm{abcd}$ & 20.10 & $\mathrm{bc}$ & $22.92 a b c$ \\
\hline
\end{tabular}

${ }^{a}$ Means in columns followed by the same letter are not significantly different at the 5\% level according to Duncan's multiple range test.

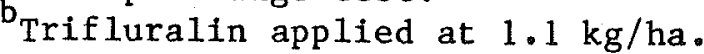
Metribuzin applied at $0.42 \mathrm{~kg} / \mathrm{ha}$. 
Append $1 x$

Table 10. Treatment effect on $\%$ protein $^{a}$.

1982

\begin{tabular}{|c|c|c|c|c|c|c|}
\hline Inoculated Control & 25.18 de & $28.70 \mathrm{ab}$ & $29.30 \quad b$ & $24.33 \mathrm{~b}$ & 19.98 bc & 25.50 \\
\hline Uninoculated Control & 26.15 bcde & $27.60 \mathrm{~b}$ & $29.23 \quad b$ & $23.78 \quad b$ & 19.48 bc & 25.25 \\
\hline Trifluralin $(0.82 \mathrm{~kg} / \mathrm{ha})$ & 26.03 bcde & $28.63 \mathrm{ab}$ & $29.15 \mathrm{~b}$ & $25.85 \mathrm{ab}$ & 18.90 & 25.71 \\
\hline Metribuzin $(0.2 \mathrm{~kg} / \mathrm{ha})$ & 26.48 abcde & $28.53 \mathrm{ab}$ & $31.43 \mathrm{ab}$ & $24.50 \quad b$ & $20.53 \mathrm{abc}$ & 26.29 bcde \\
\hline Metribuzin $(0.4 \mathrm{~kg} / \mathrm{ha})$ & 25.43 cde & $29.95 \mathrm{ab}$ & $30.45 \mathrm{ab}$ & $28.05 \mathrm{a}$ & $21.33 a b$ & $27.05 \mathrm{ab}$ \\
\hline Metribuzin $(0.6 \mathrm{~kg} / \mathrm{ha})$ & $28.25 \mathrm{a}$ & $30.63 \mathrm{a}$ & $30.58 \mathrm{ab}$ & $26.13 \mathrm{ab}$ & $22.68 \mathrm{a}$ & $27.65 \mathrm{a}$ \\
\hline$T$ at $0.8 \mathrm{~kg} / \mathrm{ha}+\mathrm{M}$ at $0.2 \mathrm{~kg} / \mathrm{ha}$ & 25.88 bcde & $29.90 \mathrm{ab}$ & $30.13 \mathrm{ab}$ & $25.55 \mathrm{ab}$ & $20.73 \mathrm{abc}$ & 26.44 bcde \\
\hline $\mathrm{T}$ at $1.1 \mathrm{~kg} / \mathrm{ha}+\mathrm{M}$ at $0.2 \mathrm{~kg} / \mathrm{ha}$ & 24.90 & $28.80 \mathrm{ab}$ & $30.08 \mathrm{ab}$ & $25.73 \mathrm{ab}$ & $19.10 \mathrm{bc}$ & 25.72 \\
\hline $\mathrm{T}$ at $1.1 \mathrm{~kg} / \mathrm{ha}+\mathrm{M}$ at $0.4 \mathrm{~kg} / \mathrm{ha}$ & $27.18 \mathrm{abc}$ & $30.13 \mathrm{a}$ & $30.78 \mathrm{ab}$ & $24.78 \quad b$ & $20.78 \mathrm{abc}$ & $26.73 \mathrm{abc}$ \\
\hline$T$ at $1.1 \mathrm{~kg} / \mathrm{ha}+\mathrm{M}$ at $0.6 \mathrm{~kg} / \mathrm{ha}$ & $26.83 \mathrm{abcd}$ & $30.23 \mathrm{a}$ & $30.63 \mathrm{ab}$ & $25.13 \mathrm{~b}$ & $20.60 \mathrm{abc}$ & 26.68 abcd \\
\hline
\end{tabular}

Duncan's multiple range test. 
Appendix

Table 11. Treatment effect on total nitrogen/plant $(\mathrm{g})^{\mathrm{a}}$. 1981

\begin{tabular}{|c|c|c|c|c|}
\hline Treatment ${ }^{b}$ & July 4 & July 24 & Aug. 10 & Overall \\
\hline Control & $0.15 \mathrm{a}$ & $0.59 \mathrm{a}$ & $0.63 \mathrm{abc}$ & $0.46 \mathrm{a}$ \\
\hline Nitrogen & 0.17 a & $0.50 \mathrm{ab}$ & $0.56 \mathrm{abcd}$ & $0.41 \mathrm{abc}$ \\
\hline Trifluralin & 0.09 bcd & 0.39 bcde & $0.73 \mathrm{a}$ & $0.40 \mathrm{abc}$ \\
\hline $\mathrm{T}+\mathrm{M}$ & $0.08 \mathrm{~cd}$ & 0.37 bcdef & $0.57 \mathrm{abcd}$ & $0.34 \mathrm{bcd}$ \\
\hline Metribuzin & $0.05 \quad d$ & 0.26 & 0.45 bcde & 0.25 def \\
\hline $\mathrm{T}+\mathrm{N}$ & $0.10 \mathrm{bcd}$ & $0.46 \mathrm{abc}$ & $0.81 \mathrm{a}$ & $0.46 \mathrm{a}$ \\
\hline $\mathrm{T}+\mathrm{M}+\mathrm{N}$ & 0.06 & 0.23 & 0.40 cde & 0.23 \\
\hline $\mathrm{M}+\mathrm{N}$ & 0.04 & 0.18 & $0.33 \mathrm{de}$ & 0.19 \\
\hline Rhizobia & $0.17 \mathrm{a}$ & cdefg & $0.63 \mathrm{abc}$ & $0.38 \mathrm{abc}$ \\
\hline $\mathrm{T}+\mathrm{RH}$ & $0.13 a b c$ & $0.44 \mathrm{bcd}$ & $0.75 \mathrm{a}$ & $0.44 \mathrm{ab}$ \\
\hline $\mathrm{T}+\mathrm{M}+\mathrm{RH}$ & $0.09 \mathrm{~cd}$ & cdefg & $0.63 \mathrm{abc}$ & $0.35 \mathrm{bc}$ \\
\hline $\mathrm{M}+\mathrm{RH}$ & 0.04 & 0.19 & 0.32 & 0.18 \\
\hline $\mathrm{N}+\mathrm{RH}$ & $0.14 \mathrm{ab}$ & $0.42 \mathrm{bcd}$ & $0.82 \mathrm{a}$ & $0.46 \mathrm{a}$ \\
\hline $\mathrm{T}+\mathrm{N}+\mathrm{RH}$ & $0.12 a b c$ & $0.46 \mathrm{abc}$ & $0.71 \mathrm{ab}$ & $0.43 \mathrm{ab}$ \\
\hline $\mathrm{M}+\mathrm{N}+\mathrm{RH}$ & 0.05 & 0.22 & 0.30 & 0.19 \\
\hline $\mathrm{T}+\mathrm{M}+\mathrm{N}+\mathrm{RH}$ & $0.09 \mathrm{bcd}$ & defgh & $0.57 \mathrm{abc}$ & 0.32 cde \\
\hline
\end{tabular}

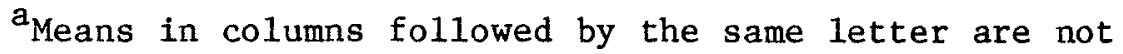
significantly different at the 5\% level according to Duncan's multiple range test.

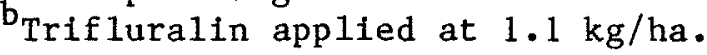
Metribuzin applied at $0.42 \mathrm{~kg} / \mathrm{ha}$. 
Appendix

Table 12. Treatment effect on total nitrogen/plant $(g)^{a}$. 1982

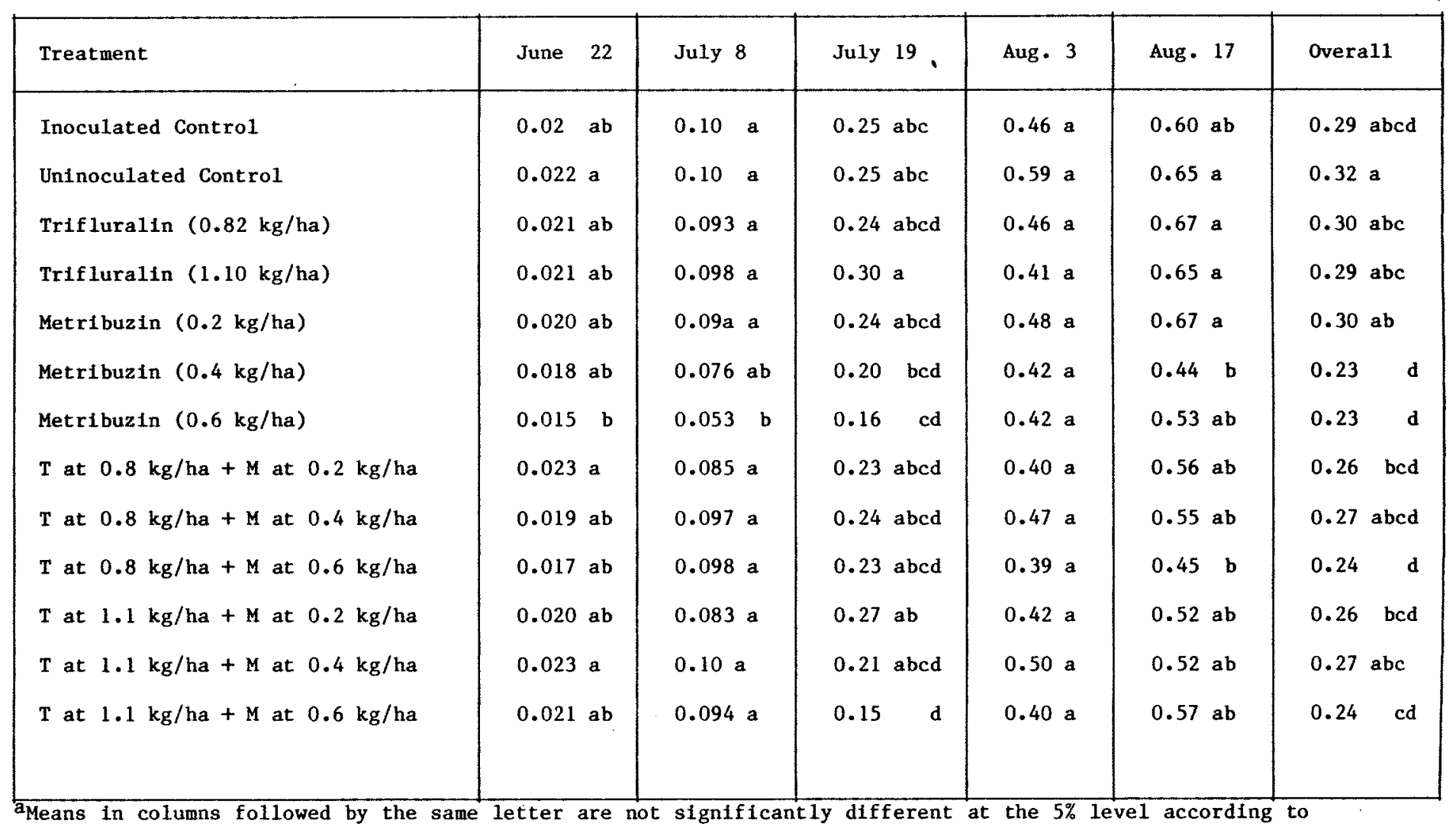

by the same letter are not significantly different at the $5 \%$ level according to Duncan's multiple range test. 
Appendix

Table 13. Treatment effect on final seed yield $(\mathrm{kg} / \mathrm{ha})^{\mathrm{a}}$. 1981

\begin{tabular}{|c|c|c|c|}
\hline \multicolumn{2}{|c|}{1981} & \multicolumn{2}{|l|}{1982} \\
\hline Treatment ${ }^{b}$ & $\begin{array}{c}\text { Yield } \\
(\mathrm{kg} / \mathrm{ha})\end{array}$ & Treatment & $\begin{array}{l}\text { Yield } \\
(\mathrm{kg} / \mathrm{ha})\end{array}$ \\
\hline Control & $2329.7 \mathrm{a}$ & Inoculated Contro1 & $2206.3 \mathrm{a}$ \\
\hline Nitrogen & $1933.3 \mathrm{ab}$ & Uninoculated Control & $1865.5 \mathrm{~b}$ \\
\hline Trifluralin & $1734.0 \mathrm{abc}$ & Trifluralin $(0.82 \mathrm{~kg} / \mathrm{ha})$ & $2169.4 \mathrm{ab}$ \\
\hline $\mathrm{T}+\mathrm{M}$ & $1385.3 \mathrm{bcd}$ & Trifluralin $(1.1 \mathrm{~kg} / \mathrm{ha})$ & $2119.6 \mathrm{ab}$ \\
\hline Metribuzin & $961.7 \mathrm{~cd}$ & Metribuzin $(0.2 \mathrm{~kg} / \mathrm{ha})$ & $2141.1 \mathrm{ab}$ \\
\hline $\mathrm{T}+\mathrm{N}$ & 1531.7 bcd & Metribuzin $(0.4 \mathrm{~kg} / \mathrm{ha})$ & $2008.4 \mathrm{ab}$ \\
\hline $\mathrm{T}+\mathrm{M}+\mathrm{N}$ & $1471.0 \mathrm{bcd}$ & Metribuzin $(0.6 \mathrm{~kg} / \mathrm{ha}$ & $1594.1 \quad \mathrm{c}$ \\
\hline$M+N$ & $799.0 \quad d$ & $\begin{array}{l}\mathrm{T} \text { at } 0.82 \mathrm{~kg} / \mathrm{ha}+\mathrm{M} \text { at } \\
0.2 \mathrm{~kg} / \mathrm{ha}\end{array}$ & $2129.1 \mathrm{ab}$ \\
\hline Rhizobia & $2435.0 \mathrm{a}$ & $\begin{array}{l}\mathrm{T} \text { at } 0.82 \mathrm{~kg} / \mathrm{ha}+\mathrm{M} \text { at } \\
0.4 \mathrm{~kg} / \mathrm{ha}\end{array}$ & $2000.8 \mathrm{ab}$ \\
\hline $\mathrm{T}+\mathrm{RH}$ & $1868.7 \mathrm{ab}$ & $\begin{array}{l}\mathrm{T} \text { at } 0.82 \mathrm{~kg} / \mathrm{ha}+\mathrm{M} \text { at } \\
0.6 \mathrm{~kg} / \mathrm{ha}\end{array}$ & $1986.0 \mathrm{ab}$ \\
\hline $\mathrm{T}+\mathrm{M}+\mathrm{RH}$ & $1413.3 \mathrm{bcd}$ & $\begin{array}{l}T \text { at } 1.1 \mathrm{~kg} / \mathrm{ha}+\mathrm{M} \text { at } \\
0.2 \mathrm{~kg} / \mathrm{ha}\end{array}$ & $2108.9 a b$ \\
\hline $\mathrm{M}+\mathrm{RH}$ & $841.7 \quad d$ & $\begin{array}{l}\mathrm{T} \text { at } 1.1 \mathrm{~kg} / \mathrm{ha}+\mathrm{M} \text { at } \\
0.4 \mathrm{~kg} / \mathrm{ha}\end{array}$ & $2058.7 \mathrm{ab}$ \\
\hline $\mathrm{N}+\mathrm{RH}$ & 2309.3 a & $\begin{array}{l}\mathrm{T} \text { at } 1.1 \mathrm{~kg} / \mathrm{ha}+\mathrm{M} \text { at } \\
0.6 \mathrm{~kg} / \mathrm{ha}\end{array}$ & $1976.1 \mathrm{ab}$ \\
\hline $\mathrm{T}+\mathrm{N}+\mathrm{RH}$ & $1953.3 \mathrm{ab}$ & - & - \\
\hline $\mathrm{M}+\mathrm{N}+\mathrm{RH}$ & $895.0 \quad d$ & - & - \\
\hline $\mathrm{T}+\mathrm{M}+\mathrm{N}+\mathrm{RH}$ & $1385.0 \mathrm{bcd}$ & - & - \\
\hline
\end{tabular}

${ }^{a}$ Means in columns followed by the same letter are not significantly different at the $5 \%$ level according to Duncan's multiple range test.

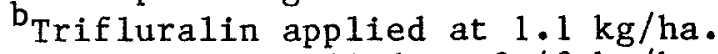
Metribuzin applied at $0.42 \mathrm{~kg} / \mathrm{ha}$. 
Appendix

Table 14. Treatment effect on plant stand (plants $\left./ \mathrm{m}^{2}\right) .^{a}$

\begin{tabular}{|c|c|c|c|}
\hline \multicolumn{2}{|c|}{1981} & \multicolumn{2}{|l|}{1982} \\
\hline Treatment $^{b}$ & $\begin{array}{l}\text { Plant Count } \\
\left.\text { (plants } / \mathrm{m}^{2}\right)\end{array}$ & Treatment & $\begin{array}{l}\text { Plant Count } \\
\left(\mathrm{plants} / \mathrm{m}^{2}\right)\end{array}$ \\
\hline Control & 38.8 & Inoculated Control & 54.5 \\
\hline Nitrogen & 35.5 & Uninoculated Control & 47.3 \\
\hline Triflura1in & 40.6 & Trifluralin $(0.82 \mathrm{~kg} / \mathrm{ha})$ & 56.5 \\
\hline $\mathrm{T}+\mathrm{M}$ & 29.6 & Trifluralin $(1.1 \mathrm{~kg} / \mathrm{ha})$ & 51.3 \\
\hline Metribuzin & 29.3 & Metribuzin $(0.2 \mathrm{~kg} / \mathrm{ha})$ & 47.8 \\
\hline $\mathrm{T}+\mathrm{N}$ & 37.0 & Metribuzin $(0.4 \mathrm{~kg} / \mathrm{ha})$ & 47.5 \\
\hline $\mathrm{T}+\mathrm{M}+\mathrm{N}$ & 29.0 & Metribuzin $(0.6 \mathrm{~kg} / \mathrm{ha}$ & 37.5 \\
\hline $\mathrm{M}+\mathrm{N}$ & 28.4 & $\begin{array}{l}\mathrm{T} \text { at } 0.82 \mathrm{~kg} / \mathrm{ha}+\mathrm{M} \text { at } \\
0.2 \mathrm{~kg} / \mathrm{ha}\end{array}$ & 51.3 \\
\hline Rhizobia & 38.2 & $\begin{array}{l}\mathrm{T} \text { at } 0.82 \mathrm{~kg} / \mathrm{ha}+\mathrm{M} \text { at } \\
0.4 \mathrm{~kg} / \mathrm{ha}\end{array}$ & 48.5 \\
\hline $\mathrm{T}+\mathrm{RH}$ & 42.7 & $\begin{array}{l}\text { T at } 0.82 \mathrm{~kg} / \mathrm{ha}+\mathrm{M} \text { at } \\
0.6 \mathrm{~kg} / \mathrm{ha}\end{array}$ & 48.5 \\
\hline $\mathrm{T}+\mathrm{M}+\mathrm{RH}$ & 35.5 & $\begin{array}{l}\mathrm{T} \text { at } 1.1 \mathrm{~kg} / \mathrm{ha}+\mathrm{M} \text { at } \\
0.2 \mathrm{~kg} / \mathrm{ha}\end{array}$ & 50.8 \\
\hline $\mathrm{M}+\mathrm{RH}$ & 29.0 & $\begin{array}{l}\mathrm{T} \text { at } 1.1 \mathrm{~kg} / \mathrm{ha}+\mathrm{M} \text { at } \\
0.4 \mathrm{~kg} / \mathrm{ha}\end{array}$ & 50.5 \\
\hline $\mathrm{N}+\mathrm{RH}$ & 43.3 & $\begin{array}{l}\mathrm{T} \text { at } 1.1 \mathrm{~kg} / \mathrm{ha}+\mathrm{M} \text { at } \\
0.6 \mathrm{~kg} / \mathrm{ha}\end{array}$ & 46.0 \\
\hline $\mathrm{T}+\mathrm{N}+\mathrm{RH}$ & 41.8 & - & - \\
\hline $\mathrm{M}+\mathrm{N}+\mathrm{RH}$ & 29.6 & - & - \\
\hline $\mathrm{T}+\mathrm{M}+\mathrm{N}+\mathrm{RH}$ & 33.4 & - & - \\
\hline
\end{tabular}

a Plant counts were made July 16, 1981 and July 7, 1982

bTrifluralin applied at $1.1 \mathrm{~kg} / \mathrm{ha}$. Metribuzin applied at $0.42 \mathrm{~kg} / \mathrm{ha}$. 